
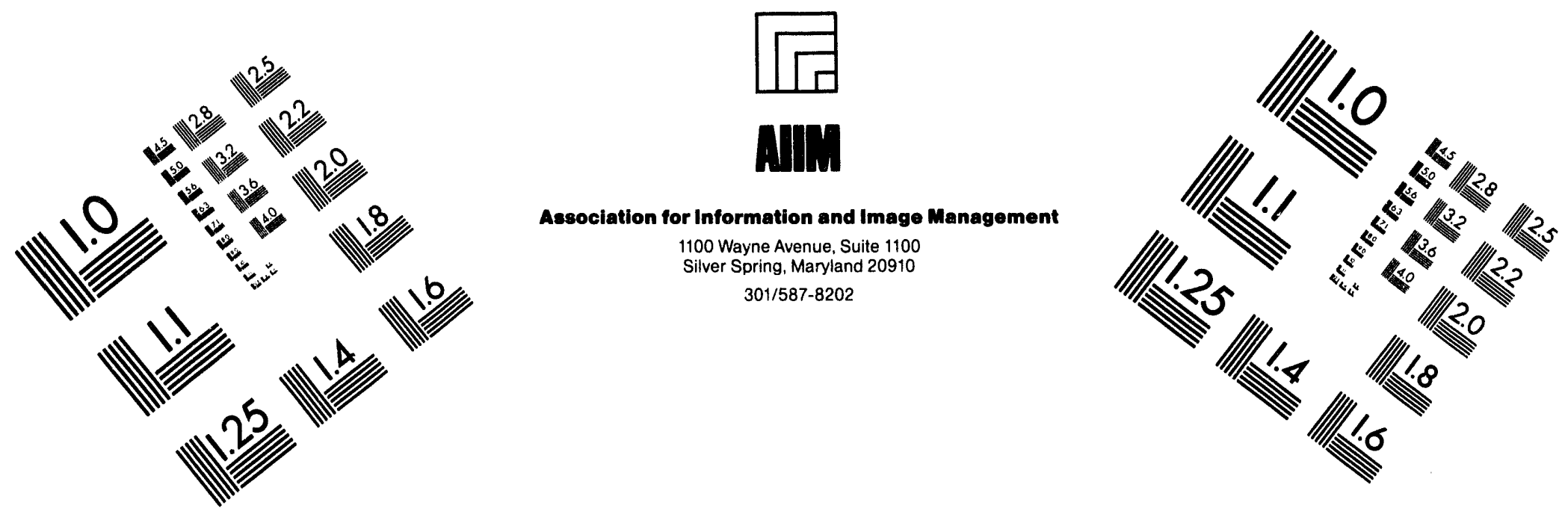

\title{
Centimeter
}

$\begin{array}{lllllllllllllll}1 & 2 & 3 & 4 & 5 & 6 & 7 & 8 & 9 & 10 & 11 & 12 & 13 & 14 & 15 \\ m m\end{array}$

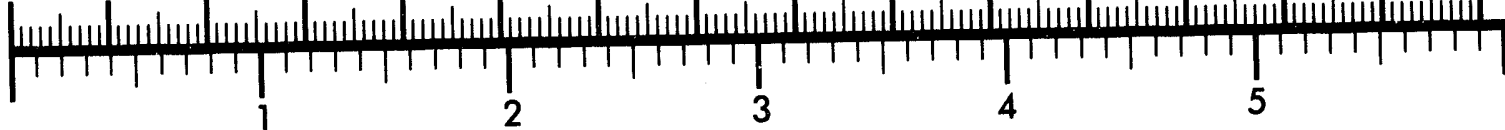
Inches
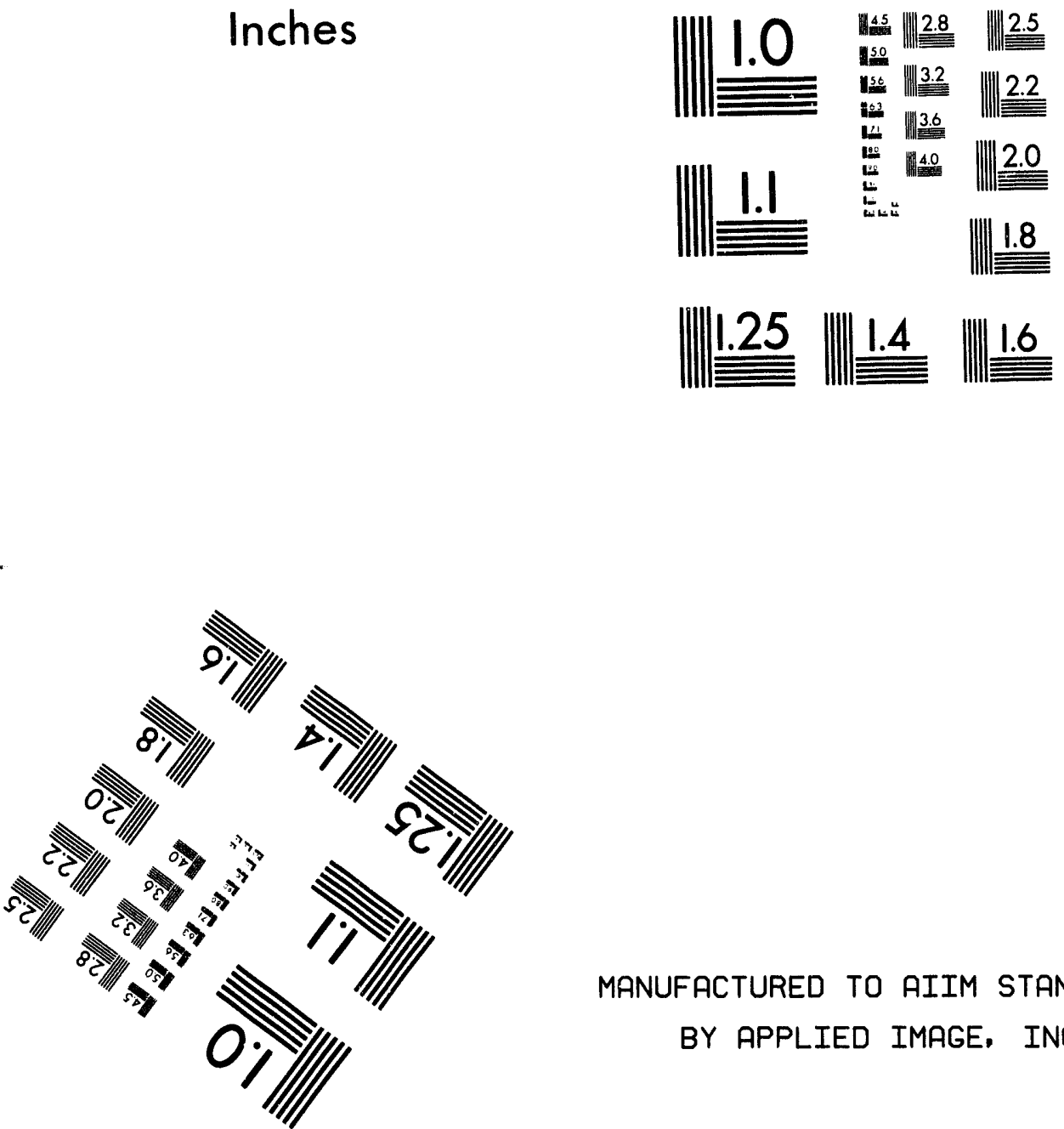

MANUFACTURED TO AIIM STANDARDS

BY APPLIED IMAGE, INC.

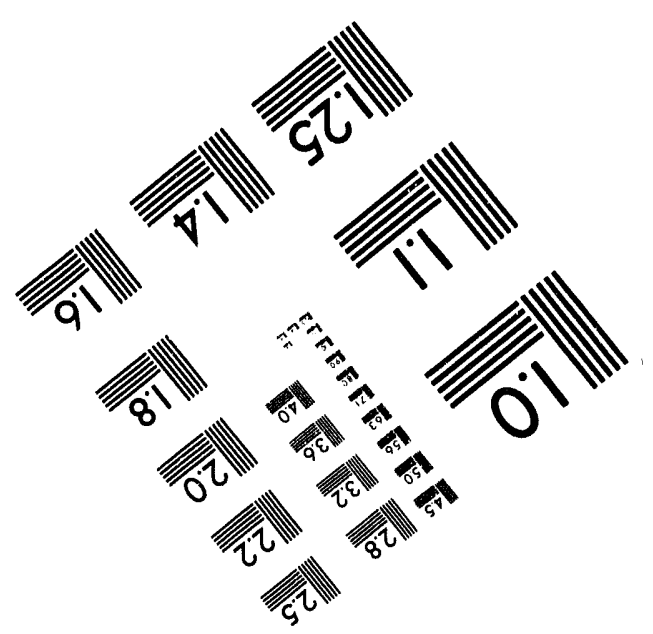



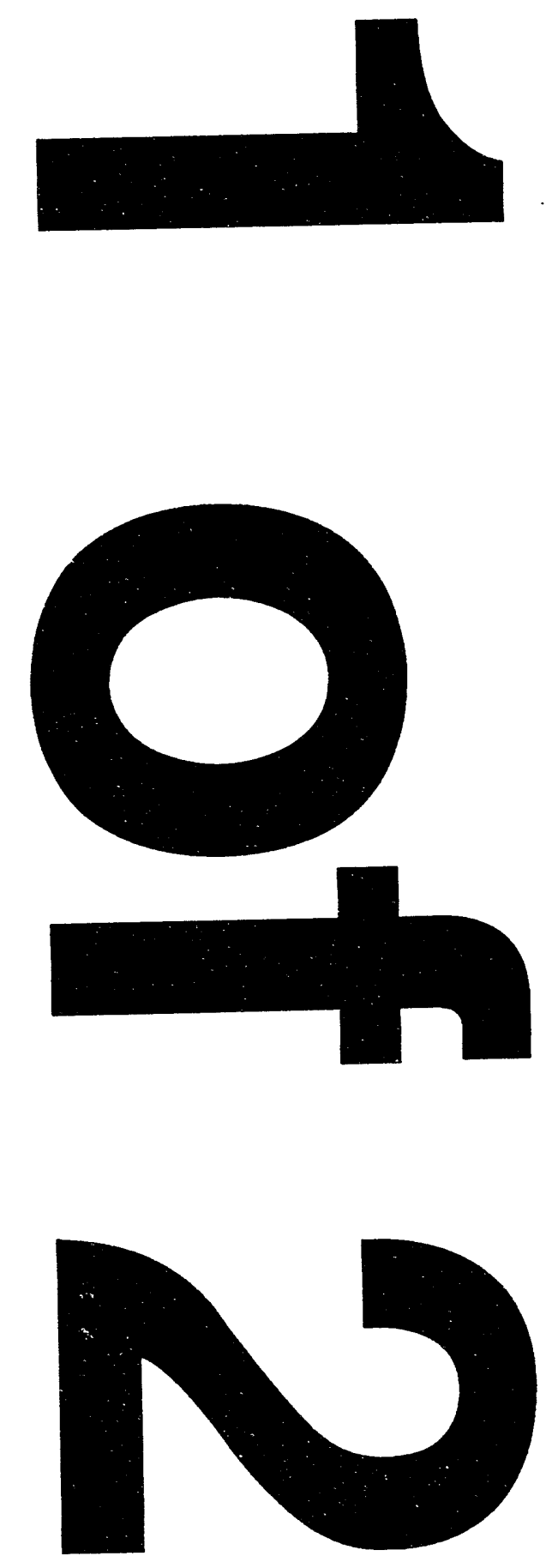
DOE/RL-94-24

Revision 0

\section{State Waste Discharge Permit Application 200-E Chemical Drain Field}

Date Published

June 1994

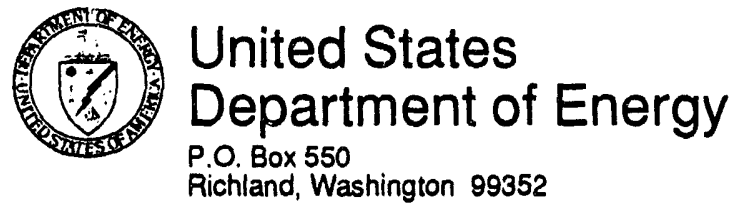

Richland, Washington 99352

Approved for Public Release

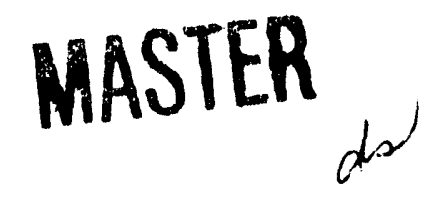

DOMnNOTION OF THIS DOCUMENT IS UNLIMITE 
DOE/RL_-94-24, Rev, 0

06/94

200-E Chemical Drain Field

\section{FOREWORD}

As part of the Hanford Federal Facility Agreement and Consent Order negotiations (Ecology et al. 1994), the U.S. Department of Energy, Richland Operations Office, the U.S. Environmental Protection Agency, and the Washington State Department of Ecology agreed that liquid effluent discharges to the ground on the Hanford Site which affect groundwater or have the potential to affect groundwater would be subject to permitting under the structure of Chapter 173-216 (or 173-218 where applicable) of the Washington Administrative Code, the State Waste Discharge Permit Program. As a result of this decision, the Washington State Department of Ecology and the U.S. Department of Energy, Richland Operations Office entered into Consent Order No. DE 91NM-177, (Ecology and DOE-RL 1991).

The Consent Order No. DE91NM-177 requires a series of permitting activities for liquid effluent discharges. Liquid effluents on the Hanford Site have been classified as Phase I, Phase II, and Miscellaneous Streams. The Consent Order No. DE91NM-177 establishes milestones for State Waste Discharge Permit application submittals for all Phase I and Phase II streams, as well as the following 11 Miscellaneous Streams as identified in Table 4 of the Consent Order No. DE91NM-177.

- 209-E Building Steam Condensate

- 400 Area Sanitary Waste Water

- 200-W Powerhouse Ash Waste Water

- 200-E Powerhouse Ash Waste Water

- 300 Area Powerhouse Ash Waste Water

- 100-N Sanitary Sewer System

- 300 Area Filter Backwash

- 300 Area Sanitary Sewer System

- 234-5Z Steam Condensate/Dry Air Compressor Cooling

- 272-E, 2703-E Buildings Waste Water

- 183-N Filter Backwash Waste Water.

This document presents the State Waste Discharge Permit (SWDP) application for the 200-E Chemical Drain Field. Waste water from the 272-E Building enters the process sewer line directly through a floor drain, while waste water from the 2703-E Building is collected in two floor drains (north and south) that act as sumps and are discharged periodically. The 272-E and 2703-E Buildings constitute the only discharges to the process sewer line and the 200-E Chemical Drain Field. 
DOE/RL-94-24, Rev, 0

06/94

200-E Chemical Drain Field

This page intentionally left blank. 
DOE/RL-94-24, Rev, 0

$06 / 94$

200-E Chemical Drain Field

CONTENTS

FOREWORD $\ldots \ldots \ldots \ldots \ldots \ldots \ldots \ldots \ldots \ldots \ldots \ldots \ldots \ldots \ldots$ iii

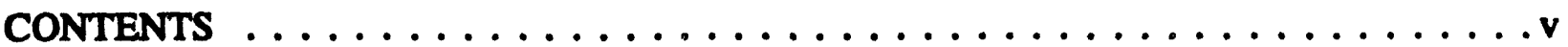

GLOSSARY $\ldots \ldots \ldots \ldots \ldots \ldots \ldots \ldots \ldots \ldots \ldots \ldots \ldots$ vii

METRIC CONVERSION CHART $\ldots \ldots \ldots \ldots \ldots \ldots \ldots \ldots$ viii

1.0 PERMTT APPLICATION $\ldots \ldots \ldots \ldots \ldots \ldots \ldots \ldots$ Application-1

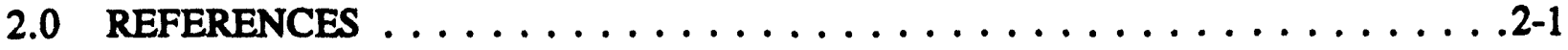

APPENDICES:

A GENERAL INFORMATION $\ldots \ldots \ldots \ldots \ldots \ldots \ldots \ldots \ldots \ldots$ A-1

B PRODUCT INFORMATION $\ldots \ldots \ldots \ldots \ldots \ldots \ldots \ldots \ldots$ B-1

C PLANT OPERATIONAL CHARACTERISTICS $\ldots \ldots \ldots \ldots \ldots \ldots \ldots$ C-1

D WATER CONSUMPTION AND WATER LOSS $\ldots \ldots \ldots \ldots \ldots \ldots \ldots$ D-1

E WASTE WATER INFORMATION $\ldots \ldots \ldots \ldots \ldots \ldots \ldots \ldots \ldots \ldots$ E-1

F STORM WATER $\ldots \ldots \ldots \ldots \ldots \ldots \ldots \ldots \ldots \ldots \ldots$ F-1

G OTHER INFORMATION $\ldots \ldots \ldots \ldots \ldots \ldots \ldots \ldots \ldots \ldots$ G-1

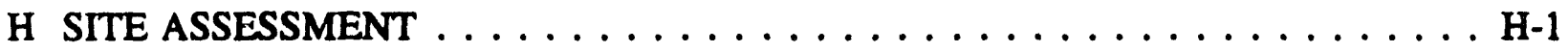


DOE/RL-94-24, Rev, 0

$06 / 94$

200-E Chemical Drain Field

This page intentionally left blank. 
DOE/RL-94-24, Rev, 0

06/94

200-E Chemical Drain Field

\section{GIOSSARY}

$\begin{array}{ll}\text { BMP } & \text { Best Management Practice } \\ \text { BOD } & \text { biological oxygen demand } \\ \text { CEL } & \text { Chemical Engineering Laboratory } \\ \text { CFR } & \text { Code of Federal Regulations } \\ \text { COD } & \text { chemical oxygen demand } \\ \text { DOE } & \text { U.S. Department of Energy } \\ \text { DOE-RL } & \text { U.S. Department of Energy, Richland Operations } \\ \text { Ecology } & \text { Washington State Department of Ecology } \\ \text { EPA } & \text { U.S. Environmental Protection Agency } \\ \text { gpd } & \text { gallons per day } \\ \text { GWQC } & \text { Ground Water Quality Criteria } \\ \text { mg/L } & \text { milligrams per liter } \\ \text { NPDES } & \text { National Pollutant Discharge Elimination System } \\ \text { PNL } & \text { Pacific Northwest Laboratory } \\ \text { PSPL } & \text { Puget Sound Power and Light Company } \\ \text { RCRA } & \text { Resource Conservation and Recovery Act } \\ \text { RCW } & \text { Revised Code of Washington } \\ \text { SIC } & \text { Standard Industrial Classification } \\ \text { SWDP } & \text { State Waste Discharge Permit } \\ \text { TKN } & \text { total Kjedldahl nitrogen } \\ \text { ug/L } & \text { micrograms per liter } \\ \text { USGS } & \text { United States Geological Survey } \\ \text { WAC } & \text { Washington Administrative Code } \\ \text { WHC } & \text { Westinghouse Hanford Company }\end{array}$


DOE/RL-94-24, Rev, 0

06/94

200-E Chemical Drin Field

\section{METRIC CONVERSION CHART}

INTO METRIC UNITS

OUT OF MICTRIC UNITS

\begin{tabular}{|c|c|c|c|c|c|}
\hline If you know & Murtiply by & To get & If you know & Multiply by & To get \\
\hline \multicolumn{3}{|c|}{ Voneth } & \multicolumn{3}{|c|}{ Veneth } \\
\hline inches & 2.54 & contimoters & centimeters & 0.393 & inches \\
\hline foet & 0.3048 & meters & metors & 3.2808 & feet \\
\hline yards & 0.914 & moters & meters & 1.09 & yards \\
\hline miles & 1.609 & kilomoters & kilometere & 0.62 & miles \\
\hline \multicolumn{3}{|c|}{ Aren } & \multicolumn{3}{|c|}{ Ares } \\
\hline square feet & 0.092 & square meters & square moters & 10.7639 & square foot \\
\hline square yards & 0.836 & square meters & square meters & 1.20 & square yards \\
\hline square miles & 2.59 & square kilometers & $\begin{array}{l}\text { square } \\
\text { kilometere }\end{array}$ & 0.39 & square miles \\
\hline acres & 0.404 & hectares & hectures & 2.471 & acres \\
\hline \multicolumn{3}{|c|}{ Mos (welght) } & \multicolumn{3}{|c|}{ Mase (welight) } \\
\hline ounces & 28.35 & grams & grams & 0.0352 & ounces \\
\hline pounds & 0.453 & kilograms & kilograms & 2.2046 & pounds \\
\hline short ton & 0.907 & metric ton & metric ton & 1.10 & short ton \\
\hline \multicolumn{3}{|c|}{ Vobume } & \multicolumn{3}{|c|}{ Volume } \\
\hline fluid ounces & 29.57 & milliliters & milliliters & 0.03 & fluid ounces \\
\hline quarts & 0.95 & liters & liters & 1.057 & quarts \\
\hline gailons & 3.79 & liters & liters & 0.26 & gallons \\
\hline cubic feet & 0.03 & cubic meters & cubic meters & 35.3147 & cubic foet \\
\hline cubic yards & 0.76 & cubic metere & cubic meters & 1.308 & cubic yards \\
\hline \multicolumn{3}{|c|}{ Temperature } & \multicolumn{3}{|c|}{ Temperature } \\
\hline Fahrenheit. & $\begin{array}{l}\text { subtract } 32 \\
\text { then multiply } \\
\text { by } 5 / 9 \text { ths }\end{array}$ & Celsius & Celsius & $\begin{array}{l}\text { multiply by } \\
\text { 9/5ths, then } \\
\text { add } 32\end{array}$ & Fahrenheit \\
\hline
\end{tabular}

Source: Lindeburg 1990. 


\subsection{PERMAT APPLICATION}

This section presents the State Waste Discharge Permit (SWDP) application for the 200-E Chemical Drain Field. Waste water from the 272-E Building enters the process sewer line directly through a floor drain, while waste water from the 2703-E Building is collected in two floor drains (north and south) that act as sumps and are discharged periodically. Waste waters from the 272-E and 2703-E Buildings constitute the only discharges to the process sewer line and the 200-E Chemical Drain Field.

\subsection{ORgANIZATION}

The Washington Administrative Code (WAC) 173-216 SWDP application form for the 200-E Chemical Drain Field is presented in this section. Information required by the SWDP application form is provided on the form when adequate space is available. Otherwise, information is provided in the appendices as noted on the completed form. The appendices follow precisely the format of the SWDP application and are designed to supplement the permit application form. Appendix A contains site location maps referenced in Section A of the permit application form. Appendices B through $\mathbf{H}$ correspond to Sections B through $\mathbf{H}$ in the permit application form. Within each appendix, those questions which require additional space have been restated and the answer directly follows the question. The questions in the appendices are worded precisely as they are in the application form, and are highlighted in bold capital letters which are underlined.

Many of the questions in the application form require separate responses for each of the contributing buildings included in the permit application. Questions requiring separate responses have been answered in the appendices. The response for the 272-E Building Waste Water is provided first followed by the response for the 2703-E Building Waste Water. This order is consistent throughout the document.

\subsection{STATE WASTE DISCHARGE PERMIT APPLICATION FORM}

The following pages contain SWDP application for the 200-E Chemical Drain Field. 
DOE/RL-94-24, Rev, 0

06/94

200-E Chemical Drain Field

This page intentionally left blank.

Application-2 


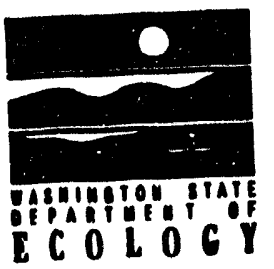

\section{STATE WASTE DISCHARGE PERMIT APPLICATION FOR INDUSTRIAL DISCHARGES TO LAND}

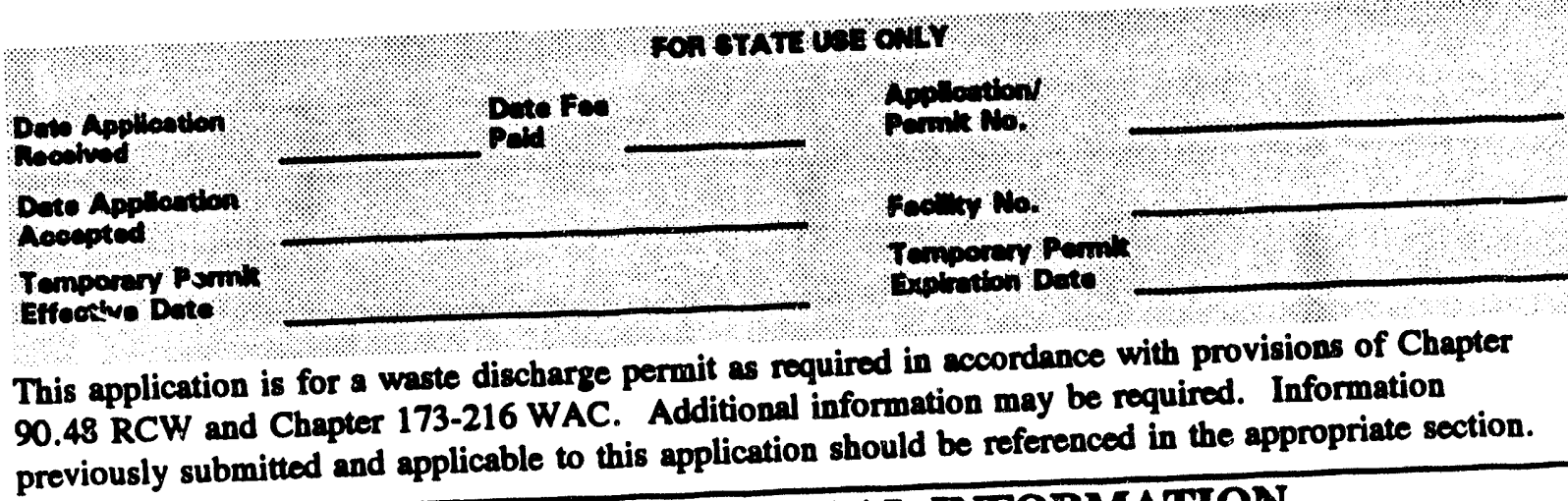

SECTION A. GENERAL INFORMATION

1. Company Name: U.S. Department of Energy, Richland Operations Office

2. Unified Business Idenditfication Number (UBIf):

91-0565159 (DOE tax exempt number)

3. Mailing Address:

P.O. Box 550

\begin{tabular}{lc} 
Richland, Washington & 99352 \\
\hline City/state & Zip
\end{tabular}

4. Facility Location: 200 East Area - Hanford Site

Street or Other Description

See Maps in Appendix A.

Citv/Stato with the information contained in this application.

5. Person to contact who is familiar with the information contained in this application
$\begin{array}{lll}\text { J. E. Rassmussen } & \text { U.S. DOE, Branch Chief, Regulatory Permits } & \text { (509) 376-2247 }\end{array}$ Name

6. Check One: $\square$ Permit Renewal

[x] Existing Unpermitted Discharge

Proposed Discharge

Anticipated date of discharge:

I certify under penalty of law that this document and all attachments were prepared under my direction or accordance with a system designed to assure that qualified personnel properly gather and evaluate the information submitted. Based on my inquiry of the person or persons who manage the system, or those persons directly responsible for gathering the information, the information submitted is, to the best of my knowledge and belief, true, accurate, and complete. I am aware that there are significant penalties for submitting flse information, including the possibility of a fine and/or imprisonment for knowing violations.

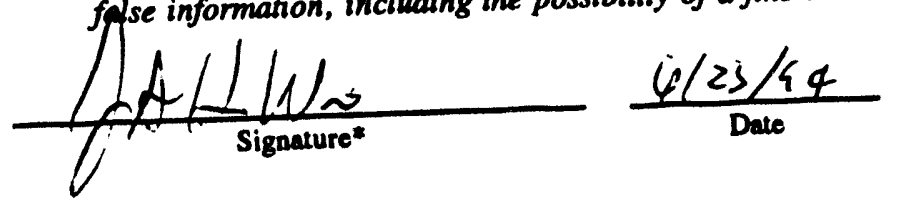

\begin{tabular}{l} 
Acting Program Manager, Office of Environmental \\
Assurance, Permits and Policy \\
\hline Title \\
Steven H. Wisness
\end{tabular} Printed Name

*Applications must be signed as follows: Corporation, by a principal executive officer of at least the level of vice-president; partnership, by a general partner; sole proprietorship, by the proprietor. 


\section{SECTION B. PRODUCT INFORMATION}

1. Briefly describe all manufacturing processes and products, and/or commercial activities. Provide the applicable Standard Industrial Classification (SIC) Code(s) for each activity. (See Standard Industrial Classification Manual, 1987 ed.)

SIC No(s): 9999

Description:See.Appendix B. Item 1.

2. Include a production schematic flow diagram of the process and service activities described above on a separate sheet. See Appendix B, Item 2

3. List raw materials and products:

\begin{tabular}{|c|c|}
\hline $\mathbf{R A W ~ M}$ & Quantity \\
\hline 272-E: Piping (carbon steel, aluminum, stainless stcel) & \multirow{5}{*}{$\begin{array}{l}\text { Stock of these items varies based on current work } \\
\text { orders. Minimal amounts of commun stock are stored. } \\
\text { The remainder of materials are ordered as needed and } \\
\text { stored for short periods of time. }\end{array}$} \\
\hline Bar (carbon steel, aluminum, or stainless steel) & \\
\hline Plate (carbon steel, aluminum, or stainless steel) & \\
\hline Angle (carbon atcel, aluminum, or stainless steel) & \\
\hline Channel (carbon steel, aluminum, or stainless steel) & \\
\hline No raw materials are stored at the 2703 Building. & See Appendix B, Item 3 for more information. \\
\hline \multicolumn{2}{|c|}{ PRODUCTS } \\
\hline 272-E: Pump ascomblies & 2 to 4 \\
\hline \multirow[t]{2}{*}{ Piping jumpers } & 100 to 120 \\
\hline & $\begin{array}{l}\text { Assemblies and jumpers are built as needed and are } \\
\text { not stockpiled. }\end{array}$ \\
\hline \multirow{2}{*}{$\begin{array}{l}\text { The 2703-E Building is a laboratory facility and does } \\
\text { not generate a product. }\end{array}$} & \\
\hline & \\
\hline & \\
\hline
\end{tabular}




\section{SECTION C. PLANT OPERATIONAL CHARACTERISTICS}

1. Identify the waste stream for each of the production processes or activities described in Section B.1. Assign each waste stream an identification number-use this number in subsequent questions.

\begin{tabular}{|c|c|c|c|}
\hline Process & Weste Stream Nome & $\begin{array}{l}\text { Batch or } \\
\text { Continuous } \\
\text { Process }\end{array}$ & $\begin{array}{l}\text { Waste } \\
\text { Stream } \\
\text { ID \# }\end{array}$ \\
\hline $\begin{array}{l}\text { Pipe and rotating equipment } \\
\text { fabrication (272-E Building) }\end{array}$ & 272-E Floor Drain & Batch & 1 \\
\hline \multirow{2}{*}{$\begin{array}{l}\text { Prototype touting laboratory } \\
\text { (2703-E Building) }\end{array}$} & North Sump & Batch & 2 \\
\hline & South Sump & Batch & 3 \\
\hline & & & \\
\hline & & & \\
\hline & & & \\
\hline & & & \\
\hline
\end{tabular}

2. On a separate sheet, describe in detail the treatment and disposal of all wastewaters as described abnve. Include a schematic flow diagram for all wastewater treatment and disposal systems. See Appendix C, Item 2.

3. Indicate treatment provided to each waste stream identified in C.1. above.

No treatment is provided to any of the waste streams identified in Section C, Item 1.

\begin{tabular}{|l|l|l|l|}
\hline $\begin{array}{c}\text { Waste } \\
\text { ID \# }\end{array}$ & \multicolumn{1}{|c|}{ Treaturent } & $\begin{array}{c}\text { Waste } \\
\text { Stream(s) } \\
\text { ID * }\end{array}$ & \multicolumn{1}{|c|}{ Treatment } \\
\hline & Air flotation & & pH correction \\
\hline & Centrifuge & & Ozonation \\
\hline & Chemical precipitation & & Reverse osmosis \\
\hline & Chiorination & & Screen \\
\hline & Cyclone & & Sedimentation \\
\hline & Filtration & & Septic tank \\
\hline & Flow equalization & & Solvent separation \\
\hline & Grease or oil separation & & Biological treatment, type: \\
\hline & Grease trap & & Rainwater diversion or storage \\
\hline & Grit removal & & Other chemical treatment type: \\
\hline & Ion exchange & & Other physical treatment type: \\
\hline
\end{tabular}


4. Describe any planned wastewater treatment improvements or changes in wastewater disposal methods and when they will occur (use additional sheets, if necessary).

There are no planned waste water treatment improvements or changes in waste water disposal methods in the 272-E and 2703-E Buildings waste waters.

5. If production processes are subject to seasonal variations, provide the following information. List discharge for each waste stream in gallons per day (GPD). The combined value for each month should equal the estimated total monthly flow.

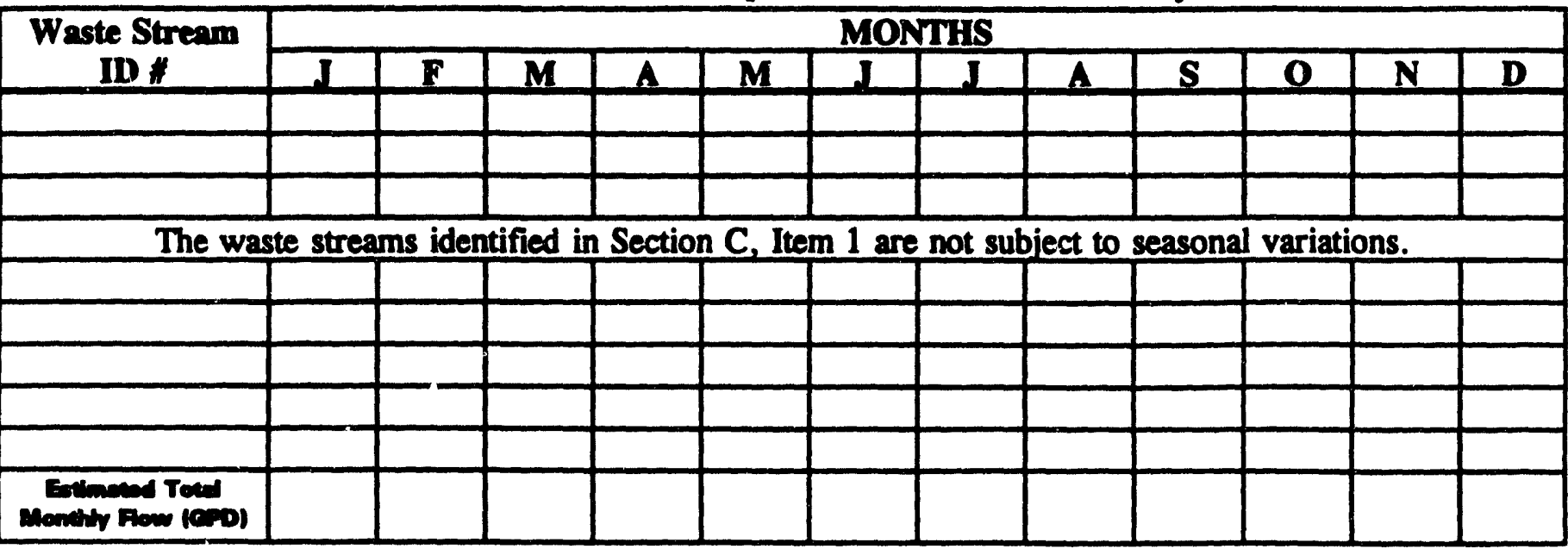

6. Shift Information:

a. Number of shifts per work day:

b. Number of work days per week:

c. Average number of work days per year:

d. Maximum number of work days per year:

e. Number of employees per shift:

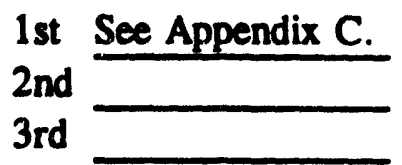

\begin{tabular}{c}
$\frac{1}{5}$ \\
\hline 252 \\
\hline 252
\end{tabular}

Shift start times

1st See Appendix C.

2nd

3rd

7. List all incidental materials like oil, paint, grease, solvents, soaps, cleaners, that are used or stored on-site. (Use additional sheets, if necessary.)

Material/Quantity Stored See Appendix C. Item 7. 
8. Describe any water recycling or material reclaiming processes:

Materials and chemicals used in the laboratory at the 2703-E Buildine are recycled when possible for reuse. There are no water recucline or material reclaiming processes in the 272-E Buildine.

9. Does this facility have: See Appendix C, Item 9.

a. Spill Prevention, Control, and Countermeasure Plan (per 40 CFR 112)?

Yes $X]$ No

b. Emergency Response Plan (per WAC 173-303-350)?

区] Yes $\square$ No

c. Runoff, spillage, or leak control plan (per WAC 173-216-110(f))?

? Yes $\square$ No

d. Does your current waste discharge permit require a spill plan? Yes $\square$ No If yes, submit an update with your application. Not Applicable.

e. Solid Waste Management Plan?

[x] Yes $\square$ No

\section{SECTION D. WATER CONSUMPTION AND WATER LOSS}

1. Water Source(s):

Public System (Specify)

Private Well

\section{Surface Water}

a. Water Right Permit Number: N/A. The U.S. Government has a reserved water right to utilize water for purposes of Hanford Site activities.

b. Legal Description:

SW 1/4S, SE 1/4S, 2 Section, 13NTWN, 25E R

2. Indicate total water use: Gallons per day (average)

Gallons per day (Maximum)

500

b. Is water metered?

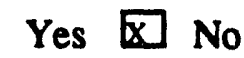

3. Attach a line drawing showing the water flow through the facility. Indicate source of intake water, operations contributing wastewater to the effluent, and treatment units labeled to correspond to the more detailed descriptions in Item C. Construct a water balance on the line drawing by showing average flows between intakes, operations, treatment units, and outfalls. If a water balance cannot be determined (e.g., for certain mining activities), provide a pictorial description of the nature and amount of any sources of water and any collection or treatment measures.

See Appendix D, Item 3. 


\section{SECTION E. WASTEWATER INFORMATION}

1. Provide measurements for treated wastewater prior to land application for the parameters listed below, unless waived by the permitting authority. All analytical methods used to meet these requirements shall, unless approved otherwise in writing by Ecology, conform to the Guidelines Establishine Test Procedures for the Analysis of Pollutants Contained in 40 CER Part 136.

\begin{tabular}{|l|l|l|l|}
\hline \multicolumn{1}{|c|}{ Parameter } & \multicolumn{1}{c|}{$\begin{array}{c}\text { Concentrations } \\
\text { Measured }\end{array}$} & \multicolumn{1}{c|}{$\begin{array}{c}\text { Anglytical } \\
\text { Method }\end{array}$} & $\begin{array}{c}\text { Detection } \\
\text { Limit }\end{array}$ \\
\hline pH & See Appendix E, Item 1. & \\
\hline Conductivity & & & \\
\hline Total Dissolved Solids & & & \\
\hline Total Suspended Solids & & & \\
\hline BOD (5 day) & & & \\
\hline COD & & & \\
\hline Ammonia-N & & & \\
\hline TKN-N & & & \\
\hline Nitrate-N & & & \\
\hline Ortho-phosphate-P & & & \\
\hline Total-phosphate-P & & & \\
\hline Total Oil \& Grease & & & \\
\hline Calcium & & & \\
\hline Magnesium & & & \\
\hline Sodium & & & \\
\hline Potassium & & & \\
\hline Chloride & & & \\
\hline Sulfate & & & \\
\hline Fluoride & & & \\
\hline Cadmium (total) & & & \\
\hline Chromium (total) & & & \\
\hline Lead (total) & & & \\
\hline Mercury & & & \\
\hline Selenium (total) & & & \\
\hline Silver (total) & & & \\
\hline Copper (total) & & & \\
\hline Iron (total) & & & \\
\hline Manganese (total) & & & \\
\hline Zinc (total) & & & \\
\hline Barium (total) & & & \\
\hline Total Coliform & & & \\
\hline
\end{tabular}


2. Wastewater characteristics for toxic pollutants.

The intent of this question is to determine which chemicals are or might be present in the process water or wastewater. For each chemical listed below:

a. Use the letter $A$ in the Absent column if the chemical is not likely to be present because it is not used in the production process or used on site.

b. Use the letter $\mathbf{S}$ in the Absent column if the chemical may be present because it is used on site, but the chemical is not uned in the production process.

c. Use the letter $\mathbf{P}$ in the Present column if the chemical is likely to be present because it is used in the production process, but the effluent has not been rested.

d. Use the letter $\mathbf{K}$ in the Present column if the effluent has been tested and the chemical was found to be present. Attach the analytical results.

Analytical Results

Wastewater Characterization for Toxic Pollutants

\begin{tabular}{|c|c|c|c|}
\hline Absent / Present & Constiment/CAS No. & Absent / Present & Constiment/CAS No. \\
\hline $\mathbf{A}$ & Acrylamide/79-06-1 & $\mathbf{A}$ & 1,2 Dichloropropane/78-87-5 \\
\hline $\mathbf{A}$ & Acrylonitrile/107-13-1 & $\mathbf{A}$ & 1,3 Dichloropropene/542-75-6 \\
\hline $\mathbf{A}$ & Aldrin/309-00-2 & $\mathbf{A}$ & Dichlorv0s/62-73-7 \\
\hline $\mathbf{A}$ & Aniline/62-53-3 & $\mathbf{A}$ & Dieldrin/60-57-1 \\
\hline $\mathbf{A}$ & Aramite/140-57-8 & $\mathbf{A}$ & 3,3' Dimethoxybenvidine/119-90-4 \\
\hline $\mathbf{A}$ & Arsenic/7440-38-2 & $\mathbf{A}$ & 3,3 Dimethylbenzidine/119-93-7 \\
\hline$\overline{\mathbf{A}}$ & Azobenzene/103-33-3 & $\mathbf{A}$ & 1,2 Dimethylhydraxine/540-73-8 \\
\hline $\bar{A}$ & Benzene/71-43-2 & $\bar{A}$ & 2,4 Dinitrotoluese/121-14-2 \\
\hline $\mathbf{A}$ & Benxidine/92-87-5 & $\mathbf{A}$ & 2,6 Dinitrotoluene/606-20-2 \\
\hline $\mathbf{A}$ & Benzo(a)pyrene/50-32-8 & $\bar{A}$ & 1,4 Dioxane/123-91-1 \\
\hline $\mathbf{A}$ & Benzotrichloride/98-07-7 & $\mathbf{A}$ & 1,2 Diphenylhydrazine/122-66-7 \\
\hline$\overline{\mathbf{A}}$ & Benzyl chloride/100-44-7 & $\bar{A}$ & Endrin/72-20-8 \\
\hline $\mathbf{A}$ & Bis(chloroethyl)ether/111-44-4 & $\bar{A}$ & Epichlorohydrin/106-89-8 \\
\hline $\mathbf{A}$ & Bis(chloromethyl)ether/542-88-1 & $\mathbf{A}$ & Ethyl acrylate/140-88-5 \\
\hline $\mathbf{K}$ & $\begin{array}{l}\text { Bis(2-ethylhexyl)phthalate/ } \\
117-81-7\end{array}$ & $\mathbf{A}$ & Ethylene dibromide/106-93-4 \\
\hline $\mathbf{A}$ & Bromodichloromet:ane/75-27-4 & $\bar{A}$ & Ethylene thioureae/96-45-7 \\
\hline$\overline{\mathbf{A}}$ & Bromoform/75-25-2 & $\mathbf{A}$ & Folpet/133-07-3 \\
\hline $\bar{A}$ & Carbazole/86-74-8 & $\overline{\mathbf{A}}$ & Furmecyclox/60568-05-0 \\
\hline $\bar{A}$ & Carbon tetrachloride/56-23-5 & $\mathbf{A}$ & Heptachlor/76-44-8 \\
\hline $\bar{A}$ & Chlordane/57-749 & $\bar{A}$ & Heptachlor epoxide/1024-57-3 \\
\hline $\bar{A}$ & Chlorodibromomethane/124-18-1 & $\mathbf{A}$ & Hexachlorobenzene/118-74-1 \\
\hline
\end{tabular}




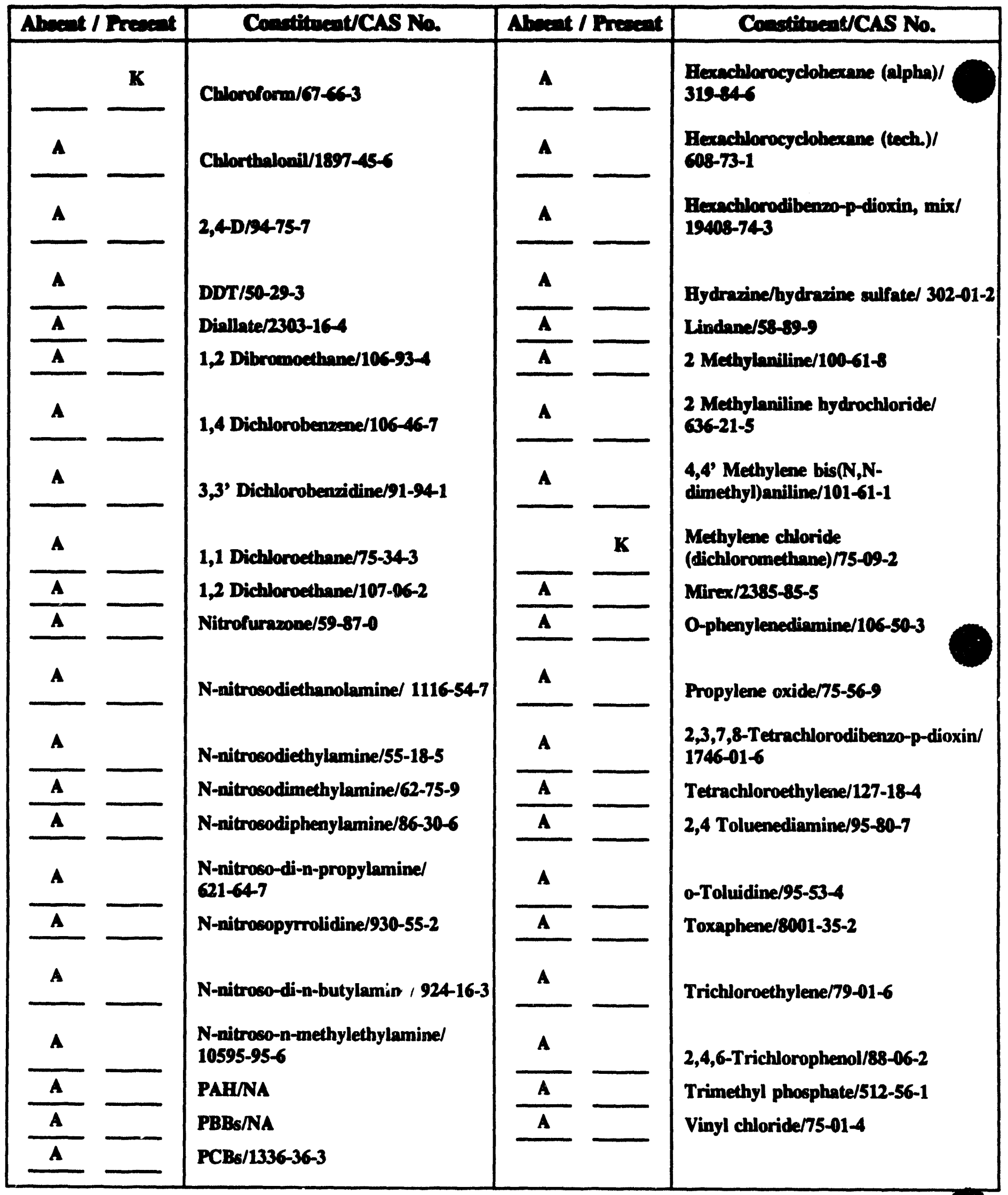




\section{SECTION F. STORMWATER}

1. Do you have a Washington State Storm Water Baseline General Permit? See Appendix F, Item 1.

Yes $\mathrm{X}$ No

If yes, please list the permit number here

2. Have you applied for a Washington State Storm Water

Baseline General Permit. See Appendix F, Item 2.

Yes $[x$ No

3. Do you have any storm water quality or quantity data?

Yes $[x$ No

Note: If you answered "yes" to questions 1 or 2 above, akip questions 4 through 8.

4. Describe the size of the storm water collection area. See Appendix F, Item 4.
a. Unpaved Area

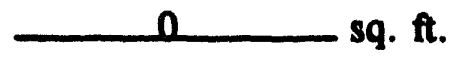
b. Paved Area
0 sq. $\mathbf{f}$.
c. Other Collection Areas (Roofs) sq. ft.

5. Does your facility's storm water discharge to: (check all that apply) See Appendix F, Item 5. Storm sewer systems; name of storm sewer system (operator):

Directly to surface waters or Washington State (e.g., river, lake, creek, estuary, ocean).

Indirectly to surface waters of Washington State (i.e., flows over adjacent properties first).

$\square$ Directly to ground waters of Washington State: $\square$ dry well $\square$ drainfield $\square$ other

6. Areas with industrial activities at facility: (check all that apply) See Appendix F, Item 6.

$\square$ Miznufacturing Building

$\square$ Material Handling

Material Storage

$\square$ Hazardous Waste Treatment, Storage, or Disposal (Refers to RCRA, Subtitle C Facilities Only)

Waste Treatment, Storage, or Disposal

Application or Lisposal of Wastewaters

Storage and Maintenance of Material Handling Equipment

Vehicle Maintenance

Areas Where Significant Materials Remain

Access Roads and Rail Lines for Shipping and Receiving

Other 
7. Material handling/management practices. See Appendix F, Item 7.

a. Types of materials handled and/or stored outdoors: (check all that apply)

$\square$ Solvents

$\square$ Hazardous Wastes

$\square$ Scrap Metal

$\square$ Acids or Alkalies

$\square$ Petroleum or Petrochemical Products

$\square$ Paints/Coatings

$\square$ Plating Products

Woodtreating Products

$\square$ Pesticides

$\square$ Other (Pleaso lint)

b. Identify existing management practices employed to reduce pollutants in industrial storm water discharges: (chec' all that apply)

$\square$ Oil/Water Separator

Detention Facilities

Containment

Infiltration Basins

$\square$ Spill Prevention

Operational BMPs

Surface Leachate Collection

Vegetation Management

$\square$ Overhead Coverage

Other (Please list)

8. Attach a map showing storm water drainage/collection areas, disposal areas and discharge points. See Appendix F, Item 8.

\section{SECTION G. OTHER INFORMATION}

1. Describe liquid wastes or sludges being generated that are not disposed of in the waste stream(s) and how they are disposed of. For each type of waste, provide type of waste, name, address, and phone number of hauler.

See Appendix G. Item 1

2. Describe storage areas for raw materials, products, and wastes.

See Appendix G. Item 2

3. Have you designated your wastes according to the procedures

of Dangerous Waste Regulations, Chapter 173-303WAC?

X Yes

$\square$ No

Page 10 of 12 


\section{SECTION H. SITE ASSESSMENT}

1. Give the legal description of the land treatment site(s). Give the acreage of each land treatment site(s). Attach a copy of the contract(s) authorizing use of land for treatment.

\section{See Appendix H. Item 1.}

2. List all environmental control permits or approvals needed for this project; for example, septic tank permits, sludge application permits, or air emissions permits.

See Appendix H. Item 2.

3. Attach a United States Geological Survey (USGS) a topographic map. Show the following on this map:

See Appendix H, Item 3.

a. Location and name of internal and adjacent streets

b. Surface water drainage systems within $1 / 4$ mile of the site

c. All wells within 1 mile of the site

d. Chemical and product handling and storage facilities

e. Infiltration sources, such as drainfields and lagoons within 1/4 mile of the site

f. Wastewater and cooling water discharge points wit waste stream ID numbers (See Section C.1)

g. Other activities and land uses within 1/4 mile of the site

4. Attach well logs and well I.D.\# when available for all wells within 500 feet and any available water quality data.

See Appendix H. Item 4. 
5. Describe soils on the site using information from local soil survey reports.

(Submit on separate sheet.)

See Appendix H, Item $\mathbf{5}$.

6. Describe the regional geology and hydrogeology within one mile of the site.

(Submit on separate sheet.)

See Appendix H, Item 6.

7. List the names and addresses of contractors or consultants who provided information and cite sources of information by title and author.

See Appendix H. Itrem Z. 
DOE/RL-94-24, Rev, 0

06/94

200-E Chemical Drain Fiold

\subsection{REFERENCES}

Baker, V. R., B. N. Bjomstad, A. J. Busacca, K. R. Fecht, E. P. Kiver, U. L. Moddy, J. G. Rigby, D. F. Stradling, and A. M. Tallman, 1991, "Quaternary Geology of the Columbia Plateau," Quaternary Nonglacial Geology; Conterminous U.S., R. B. Morrison, Editor, Geology of North America, Geological Society of America, Vol. K-2, Bouider, Colorado.

DOE, 1988, Site Characterization Plan, Reference Repository Location, Hanford Site, Washington; Consultation Draft, DOE-RW-0164, U.S. Department of Energy, Office of Civilian Radioactive Waste Management, Washington, D.C.

DOE-RL, 1993a, 200 East Groundwater Aggregate Area Management Stucty Report, DOE-RL-92-19, Rev. 0, U.S. Department of Energy, Richland Operations Office, Richland, Washington.

DOE-RL, 1993b, Phase I and II Feasibility Study Report for the 300-FF-5 Operable Unit, DOE/RL-93-22, U.S. Department of Energy, Richland Operations Office, Richlanc, Washington.

Ecology, EPA, DOE, 1994, Hanford Federal Facility Agreement and Consent Order, 2 volumes as amended, Washington State Department of Ecology, U.S. Environmental Protection Agency, and U.S. Department of Energy, Olympia, Washington.

Ecology and DOE-RL, 1991, Consent Order No. DE 91NM-177, Washington State Department of Ecology, Olympia, Washington and U.S. Department of Energy, Richland Operations Office, Richland, Washington.

EPA, 1979, Methods for the Chemical Analysis of Water and Wastes, EPA-600/4-79-020, U.S. Environmental Protection Agency, Washington D.C.

EPA, 1980, Design Manual, Onsite Wastewater Treatment and Disposal System, EPA 625/1-80-012, U.S. Environmental Protection Agency, Washington D.C.

EPA, 1992, Test Methods for Evaluating Solid Waste, Physical/Chemical Methods, SW-846, Latest Edition, U.S. Environmental Protection Agency, Washington D.C.

Fecht, K. R., S. P. Reidel, and A. M. Tallman, 1987, Paleodrainage of the Columbia River System on the Columbia Plateau of Washington: A Summary, RHO-BW-SA-318P, Rockwell Hanford Operations, Richland, Washington. 
1 Gephart, R. E., R. C. Amett, R. G. Baca, L. S. Leonhart, and F. A. Spane Jr., 1979, Hydrologic Studies Within the Columbia Plateau, Washington: An Integration of Current Knowledge, RHO-BWI-ST-5, Rockwell Hanford Operations, Richland, Washington.

Hajek, B. F., 1966, Soil Survey: Hanford Project in Benton County, Washington, BNWL-243, Pacific Northwest Laboratory, Richland, Washington.

Lindeburg, M. R., PE Engineering Unit Conversions, Second Ed, 1990, Professional Publications, Inc., Belmont, California.

Metcalf and Eddy, 1991, Wastewater Engineering: Trearment, Disposal, and Reuse, Third Edition. Revised by George Tchobanoglous and Franklin L. Burton, McGraw-Hill Publishing Company, New York, New York.

PNL, 1989, Hydrogeology of the 200 Areas Low-Level Burial Grounds - An Interim Report, PNL-6820, Pacific Northwest Laboratory, Richland, Washington.

PSPL, 1982, Skagit/Hanford Nuclear Project, Preliminary Safety Analysis Report, Vol. 4, App. 20, Amendment 23, Puget Sound Power and Light Company, Bellevue, Washington.

Reidel, S. P. and K. R. Fecht, 1981, "Wanapum and Saddle Mountains Basalt in the Cold Creek Syncline Area," Subsurface Geology of the Cold Creek Syncline, RHO-BWI-ST-14, Rockwell Hanford Operations, Richland, Washington.

Smith, G. A., B. N. Bjomstad, and K. R. Fecht, 1989, "Neogene Terrestrial Sedimentation on and Adjacent to the Columbia Plateau; Washington, Oregon, and Idaho," Volcanism and Tectonism in the Columbia River Flood-Basalt Province, Special Paper 239, S. P. Reidel and P. R. Hooper, editors, Geological Society of America, Boulder, Colorado.

Tallman, A. M., K. R. Fecht, M. C. Marratt, and G. V. Last, 1979, Geology of the Separations Areas, Hanford Site, South Central Washington, RHO-ST-23, Rockwell Hanford Operations, Richland, Washington.

WHC, 1991a, Geology and Hydrology of the 300 Area and Vicinity, Hanford Site, SouthCentral Washington, WHC-EP-0500, Westinghouse Hanford Company, Richland, Washington.

WHC, 1991b, Geology and Hydrology of the Hanford Site: A Standardized Text for Use in Westinghouse Hanford Company Documents and Reports, WHC-SD-ER-TI-003, Westinghouse Hanford Company, Richland, Washington. 
DOE/RL-94-24, Rev, 0 $06 / 94$

200-E Chemical Drain Field

1 WHC, 1991c, Geologic Setting of the 200 West Area: An Update, WHC-SD-EN-TI-008,

Rev. 0, Westinghouse Hanford Company, Richland, Washington.

WHC, 1991d, Revised Stratigraphy for the Ringold Formation, Hanford Site, South Central Washington, WHC-SD-EN-EE-004, Westinghouse Hanford Company, Richland, Washington.

WHC, 1992a, Geologic Setting of the 200 East Area: An Update, WHC-SD-EN-TI-012, Rev. 0, Westinghouse Hanford Company, Richland, Washington.

WHC, 1992b, Summary of the Geology of the 200-BP-1 Operable Unit, WHC-SD-EN-TI-037, Rev. 0, Westinghouse Hanford Company, Richland, Washington.

WHC, 1993a, Characterization Report for the Table 4 Miscellaneous Streams in Consent Order No. DE 91NM-177, WHC-EN-EV-020, Westinghouse Hanford Company, Richland, Washington.

WHC, 1993b, Hanford Site Stormwater Pollution Prevention Plan, WHC-SD-EN-EV-021, Rev. 0, Westinghouse Hanford Company, Richland, Washington.

WHC, 1993c, Sampling and Analysis Plan for Miscellaneous Streams, WHC-SD-WM-PNL-069, Rev. 0, Westinghouse Hanford Company, Richland, Washington.

WHC, 1994, Groundwater Map of the Hanford Site, WHC-EP-0394-7, Westinghouse Hanford Company, Richland, Washington. 
DOE/RL-94-24, Rev, 0

06/94

200-E Chemical Drain Fiold

1
2
3
4
5
6

This page intentionally left blank. 
DOE/RL-94-24, Rev, 0 06/94

200-E Chemical Drin Field

\section{APPENDICES}

APPENDIX A GENERAL INFORMATION $\ldots \ldots \ldots \ldots \ldots \ldots \ldots$ A-1

APPENDIX B PRODUCT INFORMATION $\ldots \ldots \ldots \ldots \ldots \ldots \ldots$ B-1

APPENDIX C PLANT OPERATIONAL CHARACTERISTICS $\ldots \ldots \ldots .$.

APPENDIX D WATER CONSUMPTION AND WATER LOSS $\ldots \ldots \ldots$ D-1

APPENDIX E WASTE WATER INFORMATION $\ldots \ldots \ldots \ldots \ldots \ldots$ E-1

APPENDIX F $\quad$ STORM WATER $\ldots \ldots \ldots \ldots \ldots \ldots \ldots \ldots \ldots$ F-1

APPENDIX $\mathbf{G}$ OTHER INFORMATION $\ldots \ldots \ldots \ldots \ldots \ldots \ldots$ G-1

APPENDIX H SITE ASSESSMENT $\ldots \ldots \ldots \ldots \ldots \ldots \ldots \ldots \ldots$ H-1 
DOE/RL-94-24, Rev, 0

06/94

200-E Chemical Drain Field

1

2

3

4

5

6

This page intentionally left blank.

App-ii 
DOE/RL-94-24, Rev, 0 06/94

200-E Chemical Drain Field

\section{APPENDDX A}

GENERAL NNORMATION

App A-i 
DOE/RL-94-24, Rev, 0

06/94

200-E Chemical Drain Field

1
2
3
4
5
6

This page intentionally left blank. 
DOE/RL-94-24, Rev, 0

06/94

200-E Chemical Drin Field

CONTENTS

\section{EIGURES}

A-1 General Hanford Site Map . . . . . . . . . . . . . . . . A-1

A-2 Location of the 200-E Chemical Drain Field. . . . . . . . . . . . A-2 
DOE/RL-94-24, Rev, 0

06/94

200-E Chemical Drain Fiald

This page intentionally left blank. 
DOE/RL-94-24, Rev, 0

06/94

200-E Chemical Drain Field

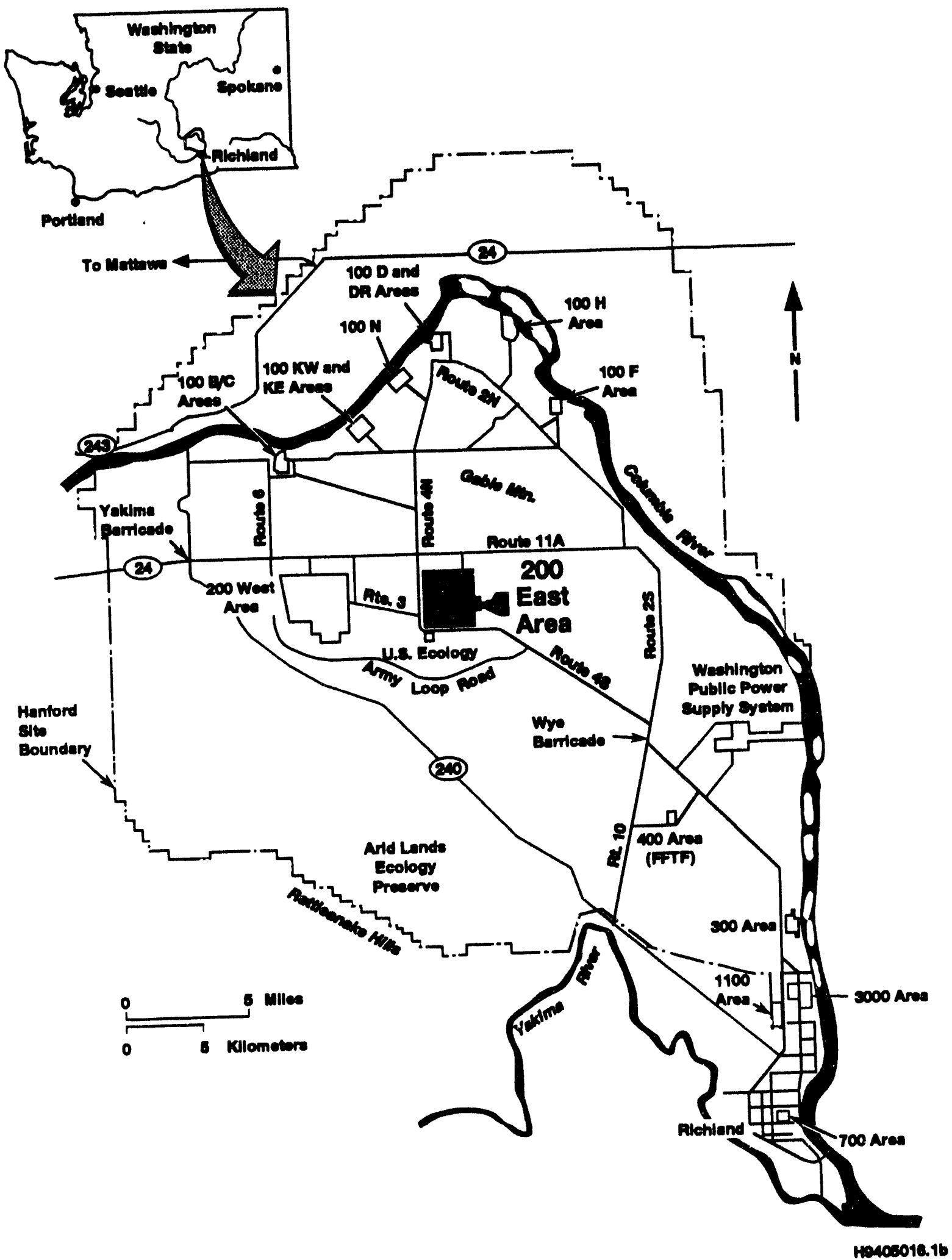

Figure A-1. General Hanford Site Map. 


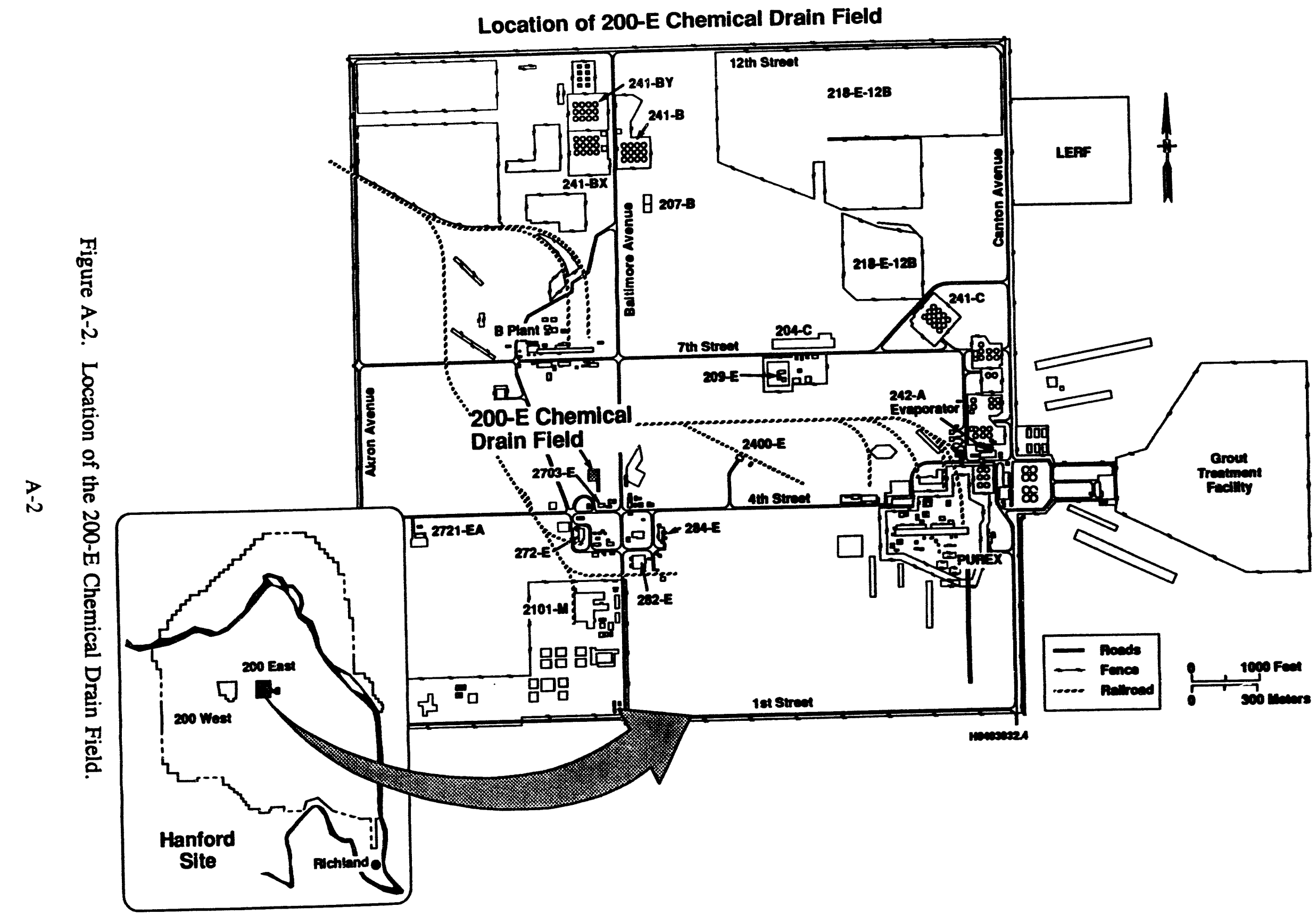

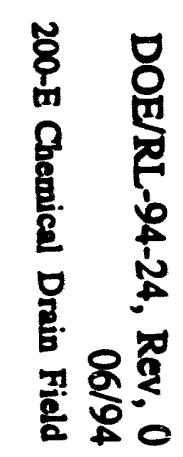


DOE/RL-94-24, Rev, 0

06/94

200-E Chemical Drain Fiold

APPENDEX B

PRODUCT INFORMATION

App B-i 
DOE/RL-94-24, Rev, 0

06/94

200-E Chamical Drin Field

1
2
3
4
5
6

This page intentionally left blank.

App B-ii 
DOE/RL-94-24, Rev, 0 $06 / 94$

200-B Cusmical Drain Fiold

\section{CONTENTS}

\section{SECTION B, ITEM 1}

BRIEFLY DESCRIBE ALL MANUFACTURING PROCESSES AND

PRODUCTS, AND/OR COMMERCIAL ACTTVTTIES . . . . . . . . . . B-1

SECTION B, ITEM 2

INCLUDE A PRODUCTION SCHEMATIC FLOW DIAGRAM OF

THE PROCESS AND SERVICE ACTIVITIES DESCRIBED ABOVE

ON A SEPARATE SHEET. $\ldots \ldots \ldots \ldots \ldots \ldots \ldots \ldots \ldots \ldots$ B-4

SECTION B, ITEM 3

LIST RAW MATERIALS AND PRODUCTS $\ldots \ldots \ldots \ldots \ldots \ldots \ldots \ldots$ B-4

\section{EIGURES}

B-1 Water Sources, Activities and Liquid Effluents at the 272-E Building. . . . . . B B-5

B-2 Water Sources, Activities and Liquid Effluents at the 2703-E Building . . . . . B B-6 
DOE/RL-94-24, Rev, 0

06/94

200-E Chemical Drain Field

1
2
3
4
5
6

This page intentionally left blank. 


\section{SECTION B, ITEM 1}

\section{BRTEFUY DESCRIBE ALL MANUEACTURNGG PROCESSES AND PRODUCTS. AND/OR COMMTERCIAL ACTVVTUIES.}

\section{NTRODUCTION}

The 200-E Chemical Drain Field, located in the 200 East Area of the Hanford Site (Figures A-1 and A-2, Appendix A), receives waste water from the 272-E and 2703-E Buildings. Waste water from the 272-E Building floor drain discharges to a process sewer line on the east side of the building which extends north to the 200-E Chemical Drain Field. Waste water from two floor sumps in the 2703-E Building is discharged to the same process sewer line and combines with the effluent from the 272-E Building before reaching the disposal site. The 272-E floor drain and the north and south sumps in the 2703-E Building are the three contributors to the waste water stream discharging to the 200-E Chemical Drain Field. The combined waste water flow varies depending on the activities inside each of the buildings.

Facility and process descriptions for the 272-E and 2703-E Buildings are given in the following sections. In addition, a description of the disposal site is provided. This information has been summarized from the Characterization Report for the Table 4 Miscellaneous Streams in Consent Order DE-91NM-177 (WHC 1993a).

\section{FACILITY AND PROCESS DESCRIPTIONS}

\section{2-E Bullding}

The 272-E Building houses a pipe and rotating-equipment fabrication shop. The north end of the building is designated as the pipe fitting area and the south end is where pumps are fabricated and tested. The major activities in this building are hydrotesting of piping jumpers, welding for the fabrication of equipment, and testing of pump assemblies. Water sources to the 272-E Building, major activities inside the building, and effluent streams from the building are shown in Figure B-1. Hydrostatic testing of pipes and testing of pump assemblies are the two processes that discharge waste water to the floor drain. Domestic waste water and steam condensate do not contribute to the waste water referred to in this application.

Hydrotesting equipment is located in the western-central portion of the building. Hydrotesting is conducted on sections of pipes to ensure pipe integrity under specific pressure conditions. Hoses and clamps that enable the flow to be interrupted are connected to each end of the pipe. Sanitary water is used to flush out the length of pipe and the water 
1 is discharged through hoses to the floor drain. After the pipe has been flushed, the clamp on 2 the trailing end is tightened and water is no longer allowed to flow to the floor drain. The 3 water pressure is increased in the pipe for testing purposes. Once the test is completed, the 4 clamp at the trailing end is opened and the water is discharged to the floor drain. Finally, a 5 stream of air is passed through the hose and pipe for drying.

\section{3-E Building}

The 2703-E Building, also known as the Chemical Engineering Laboratory (CEL), supports a variety of onsite activities. Prototypes of new and existing processes used on the Hanford Site are constructed in the CEL. A majority of floor space in the 2703-E Building is used in the construction of these prototypes. The CEL also tests process equipment, such as pumps for integrity using various fluids as applicable, and creates simulated materials to test mechanical equipment. For example, core material has been fabricated to test core sampling equipment. The simulated materials are made to meet certain specifications, such as hardness and density. A small area of the building containing a laboratory is used to generate these test solutions and simulated materials.

Water sources to the 2703-E Building, major activities inside the building, and effluent streams from the building are shown in Figure B-2. Waste water from the 2703-E Building is collected in two floor sumps before discharge to the 200-E Chemical Drain Field. Waste water includes floor wash, rinse water from cleaning containers and laboratory ware, cooling water from condensers, steam condensate from two steam boilers, a wet scrubber on the ventilation system, and nonregulated (under WAC 173-303) laboratory waste solutions. In addition, a sink inside the wet laboratory hood drains to the south sump. The wet laboratory 
DOE/RL-94-24, Rev, 0

$06 / 94$

200-E Chemical Drain Field

1 hood is used to test small scale prototypes that have been constructed by personnel at the

2 CEL. Domestic waste water and organic and inorganic laboratory waste solutions are not

3 discharged to the 200-E Chemical Drain Field.

The boilers and condensers are operational only if these are used as part of the apparatus being tested inside the CEL. When in use, the steam condensate is discharged to the sump. The condenser cooling water is discharged directly to the process sewer lines via a vertical pipe situated in the middle of the north sump.

A wet scrubber is available for cleaning the air that flows through the ventilation system inside the CEL. The scrubber is used, as needed, as determined by the scope of tests defined in approved test plans. When in use, the scrubber water is routed to a collection tank (poly tank) located near the north sump. Based on the test process, the waste is either nonregulated and is discharged to the sump or it is regulated (under WAC 173-303) and placed in waste containers. The scrubber has not operated since 1988.

Liquid waste from the laboratory inside the CEL also could be discharged to the process sewer lines via the vertical pipe situated in either sump. However, written approval from Westinghouse Hanford Company (WHC) Solid Waste Management is required, stating that the liquid waste is nonregulated. A description of the liquid waste in the container is transmitted to WHC Solid Waste Management. WHC Solid Waste Management determines whether or not the liquid waste is regulated and cites the available options for disposal. If the liquid waste is nonregulated, it is discharged directly to the process sewer line.

Waste generated at the 2703-E Building that does not discharge to the 200-E Chemical Drain Field includes regulated organic and inorganic waste generated in the laboratory and nonregulated domestic waste water generated from bathrooms, showers, etc. Regulated organic and inorganic waste is collected in satellite waste accumulation areas. When a satellite waste container is full, it is transferred to the 90-day dangerous waste storage pad outside of the 2703-E Building for subsequent transfer to the 616 Nonradioactive Dangerous Waste Storage Facility.

Sanitary water is supplied to the bathrooms, showers, sinks, hoses, and processes by one sanitary water line that enters the building on the south side.

Support structures surround the CEL, such as maintenance shops, a 90-day dangerous waste storage pad, and chemical storage buildings. However, none of the support structures discharge waste water to the process sewer line. 
DOE/RL-94-24, Rev, 0

06/94

200-E Chemical Drain Field

\section{Disposel Site Description}

The process sewer line that carries waste from the 272-E and 2703-E Buildings continues north out of the 2703-E Building until the line terminates at a headwall located at the south end of a trench. The trench continues north for 155 feet until it discharges into a seepage basin which is a 155-foot square with side slopes of 2-1/2 feet. The seepage basin, referred to as the 200-E Chemical Drain Field, has not been baclfilled or filled with any materials that would facilitate drainage.

At present, there are no free-standing liquids in the 200-E Chemical Drain Field, and there have not been any for approximately 10 years. There is no sign of natural vegetative growth in the 200-E Chemical Drain Field.

\section{SECTION B, ITEM 2}

\section{INCLUDE A PRODUCTION SCHEMATIC FLOW DIAGRAM OF THE PROCESS AND SERVICE ACTIVITIES DESCRIBED ABOVE ON A SEPARATE SHEET.}

Figures B-1 and B-2 provide flow diagrams of water supplied to each building, the activities performed, and the waste water generated by each building. Refer to Figure C-1 for the disposal of the generated waste streams.

\section{SECTION B, ITEM 3}

\section{LIST RAW MATERIALS AND PRODUCTS}

The 2703-E Building is a laboratory that does not produce specific products. In this context, the laboratory does not have raw materials that normally would be used to produce a product. 


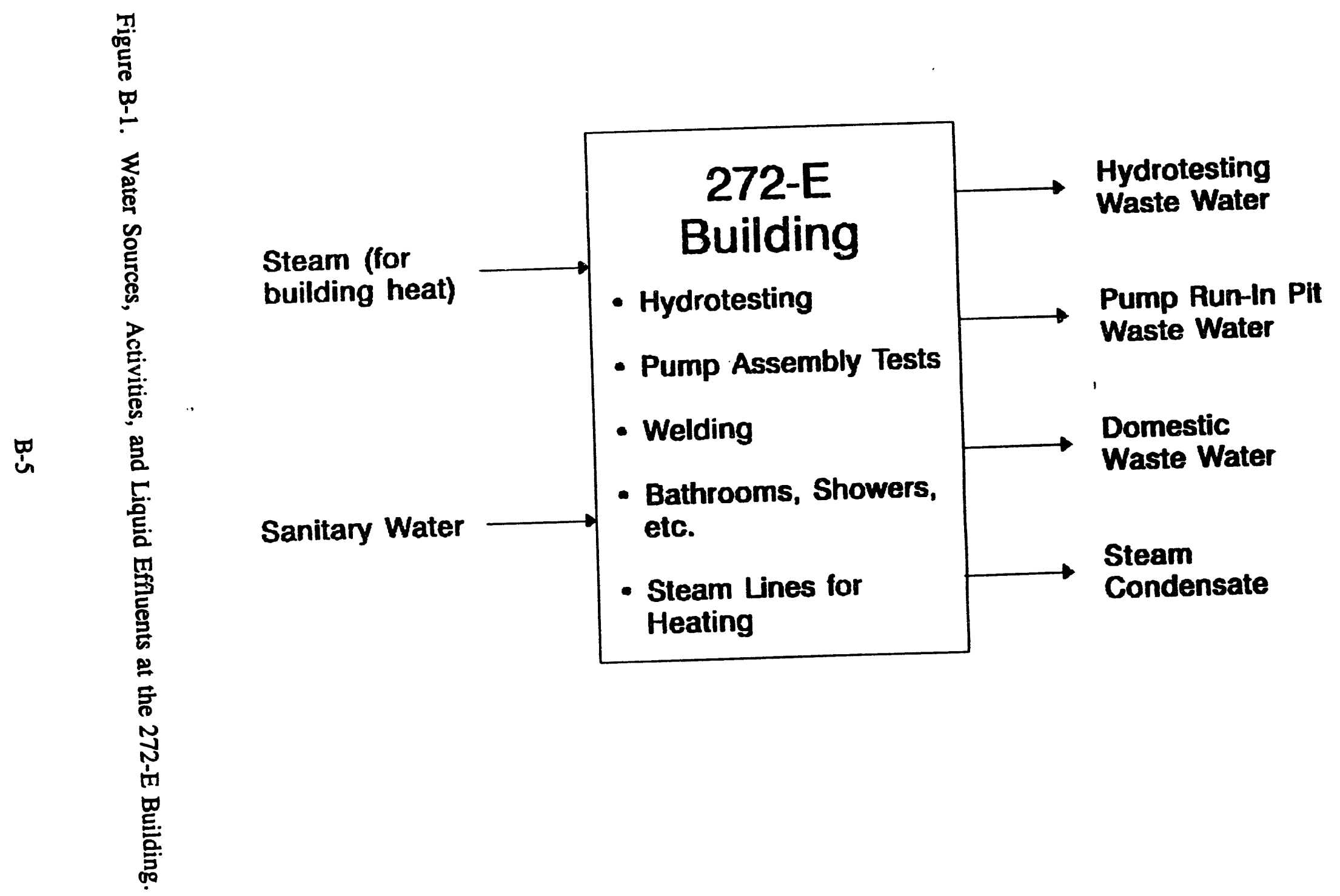




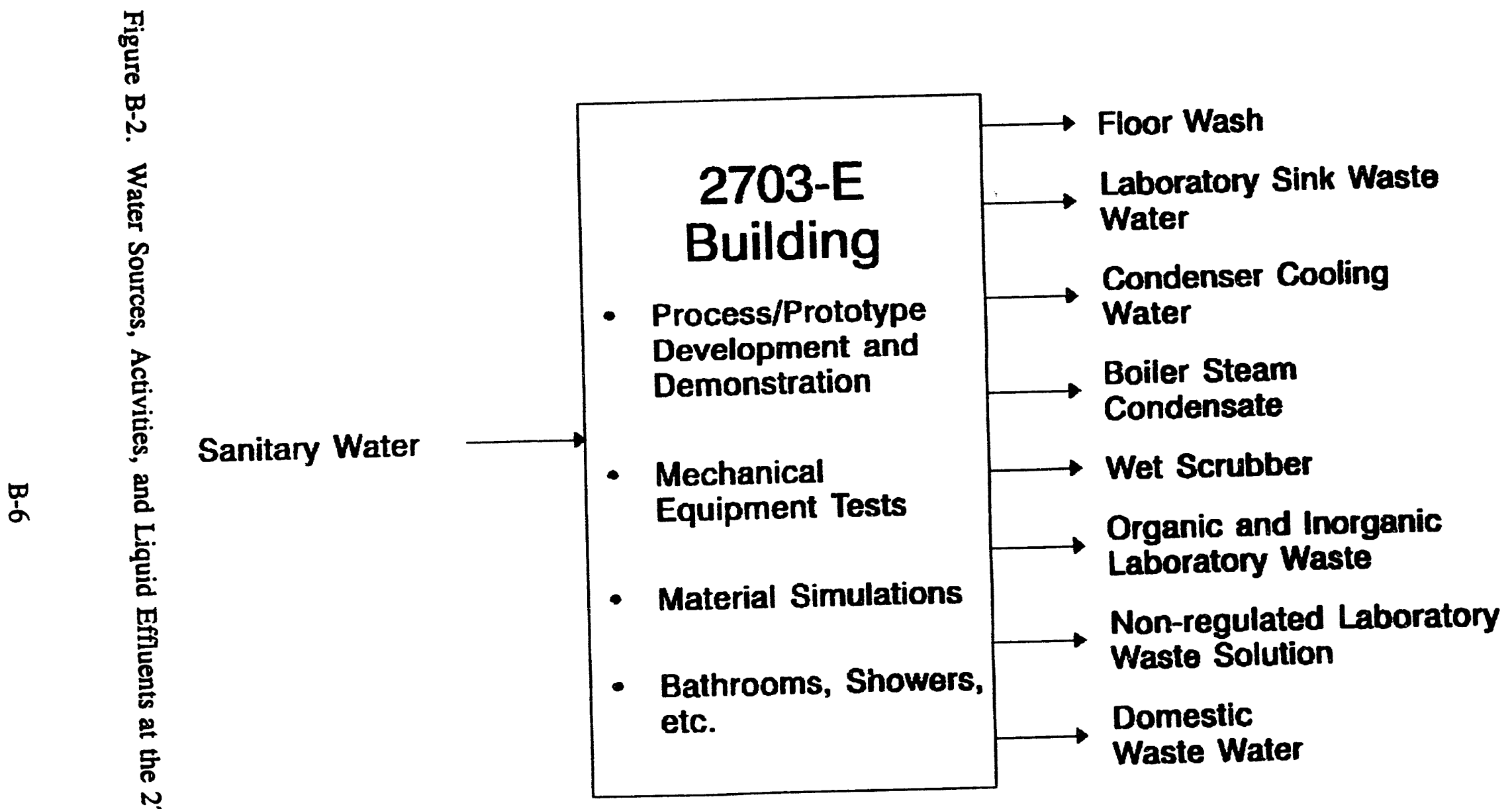


DOE/RL-94-24, Rev. 0

06/94

200-E Cremical Drain Fiold

APPENDIX C

PLANT OPERATIONAL CHARACTERISTICS

App C-i 
DOE/RL-94-24, Rev. 0

06/94

200-E Chemical Drain Field

This page intentionally left blank.

App C-ii 


\section{CONTENTS}

\section{SECTION C, ITEM 2.}

ON A SEPARATE SHEET, DESCRIBE IN DETAIL THE TREATMENT

AND DISPOSAL OF ALL WASTE WATERS AS DESCRIBED ABOVE.

INCLUDE A SCHEMATIC FLOW DIAGRAM FOR ALL WASTE

WATER TREATMENT AND DISPOSAL SYSTEMS.

SECTION C, ITEM 6

SHIFT INFORMATION: $\ldots \ldots \ldots \ldots \ldots \ldots \ldots \ldots \ldots \ldots \ldots$ C-4

SECTION C, ITEM 7

LIST ALL INCIDENTAL MATERIALS LIKE OIL, PAINT, GREASE, SOLVENTS, SOAPS, CLEANERS, THAT ARE USED OR STORED

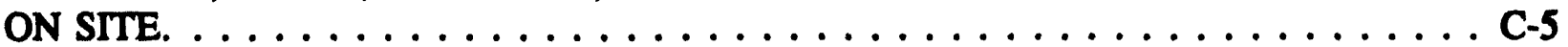

SECTION C, ITEM 9

272-E

\section{TABLES}

C-1 Summary of Incidental Materials at the 272-E Building . . . . . . . . C-6

C-2 Summary of Selected Chemicals and Other Incidental Materials at the 2703-E Building and the Conex Box . . . . . . . . . . . . . . C-7

\section{EIGURE}

C-1 Disposal Routes for Wastes Generated at the 272-E and 2703-E Buildings . . . . C-3 
DOE/RL-94-24, Rev. 0

06/94

200-E Chemical Drain Field

1

2

3

4

5

6

This page intentionally left blank. 
2

SECTION C, ITEM 2.

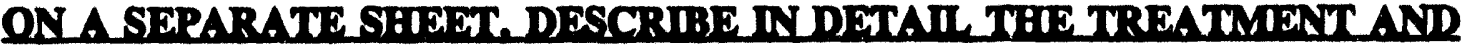

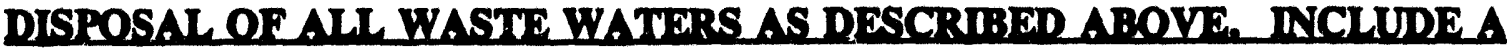 SCABMATUC FUOW DIAGRAM FOR AML WASTES WATOR TR WATMTANT AND DISPOSAL SYSTTMMS.}

\section{Treatment and Disposal of Waste Water in the 272-E Bullding}

There is no treatment of the 272-E Building waste water before discharge to the floor drain and disposal in the 200-E Chemical Drain Field. Figure C-1 provides a schematic flow diagram of the waste water generated and its disposal route. The disposal of waste water from the 272-E Building is discussed in the following paragraphs.

The 272-E Building floor drain is connected to a process sewer line that leads to the 200-E Chemical Drain Field. Waste water from the 272-E Building, identified as waste stream ID \#1, is deposited in the 200-E Chemical Drain Field.

Hydrotesting activities and pump assembly testing activities, as discussed in Section B of this permit application, are conducted using sanitary water. After testing has been performed, the water is discharged directly to the floor drain.

\section{Treatment and Disposal of Waste Water in the 2703-E Building}

The 2703-E Building waste water is not treated before discharging to the process sewer line and being disposed of in the 200-E Chemical Drain Field. Figure C-1 provides a schematic flow diagram of the waste water disposal systems from the 2703-E Building. The disposal of waste water from the 2703-E Building is discussed in the following paragraphs.

With the exception of the condenser cooling water and nonregulated laboratory waste, each of the 2703-E Building wastes shown in Figure C-1 that discharge to the process sewer line is collected in one of two floor trenches that act as sumps. These trenches are the north and south sumps. Approximately once a week, the waste water is tested for $\mathrm{pH}$ and occasionally conductivity. If these measurements fall within acceptable limits ( $2<\mathrm{pH}<12$, conductivity $<500$ micromhos), the sumps are discharged through the process sewer line to the 200-E Chemical Drain Field. After discharge, the sumps are vacuumed to remove any remaining grit particles. If the conductivity and/or $\mathrm{pH}$ measurements do not fall within acceptable limits, the waste water is transferred to waste containers and is handled in accordance with direction from WHC Solid Waste Management. 
Condenser cooling water and nonregulated laboratory waste, as described in Appendix B, are discharged through one of two open pipes that extend vertically from the center of the sumps. The pipe heights are greater than the height of the sumps so that waste water contained in the sumps cannot enter the process sewer line through the pipes unless valves at the base of the pipes are opened. The vertical pipes discharge directly to the process sewer line. The waste water collected in the north sump is identified as ID $/ 2$ and the waste water collected in the south sump is identified as $\mathrm{ID} * 3$. Additional information on the waste water streams is provided in the following paragraphs.

The 2703-E Building floors are washed approximately once a week with sanitary water. The floor of the building is slightly sloped so that rinse water collects in the north and south floor sumps.

The laboratory sink is used for washing and rinsing laboratory ware. Sanitary water is supplied to the sink and the sink drain outlets into the building's south sump.

Condensers are occasionally used in prototypes of processes being tested inside the building. When condensers are operating, the cooling water is diverted directly to the process sewer line via a vertical pipe situated in the middle of the north sump. Occasionally, an apparatus with a condenser is constructed and tested inside a hood. In this case, the condenser cooling water is discharged through a hose to the hood sink. The hood sink drains to the south sump.

Boilers also could be used to provide steam for heating coils in prototypes of processes being tested. The steam condensate generated is discharged to the north sump.

The wet scrubber operates as required on the hood and vessel ventilation system to clean the air of particulates before emission to the atmosphere. The stream of water used by the scrubber is diverted to a collection tank (poly tank) located next to the north sump. The poly tank contents are either discharged to the sump or put into waste containers following either a formal waste designation or a determination of suitability for discharge to the sumps based on process knowledge. If a formal waste designation determines that the scrubber stream is regulated, the waste in the collection tank is transferred to the 2703-E 90-day dangerous waste storage pad and subsequently transferred to the 616 Nonradioactive Dangerous Waste Storage Facility. There has been no need to scrub the ventilation stream emanating from prototype tests in recent years. The scrubber is not in use and has not operated since 1988. 
DOE/RL-94-24, Rev, 0

06/94

200-E Chemical Drain Field

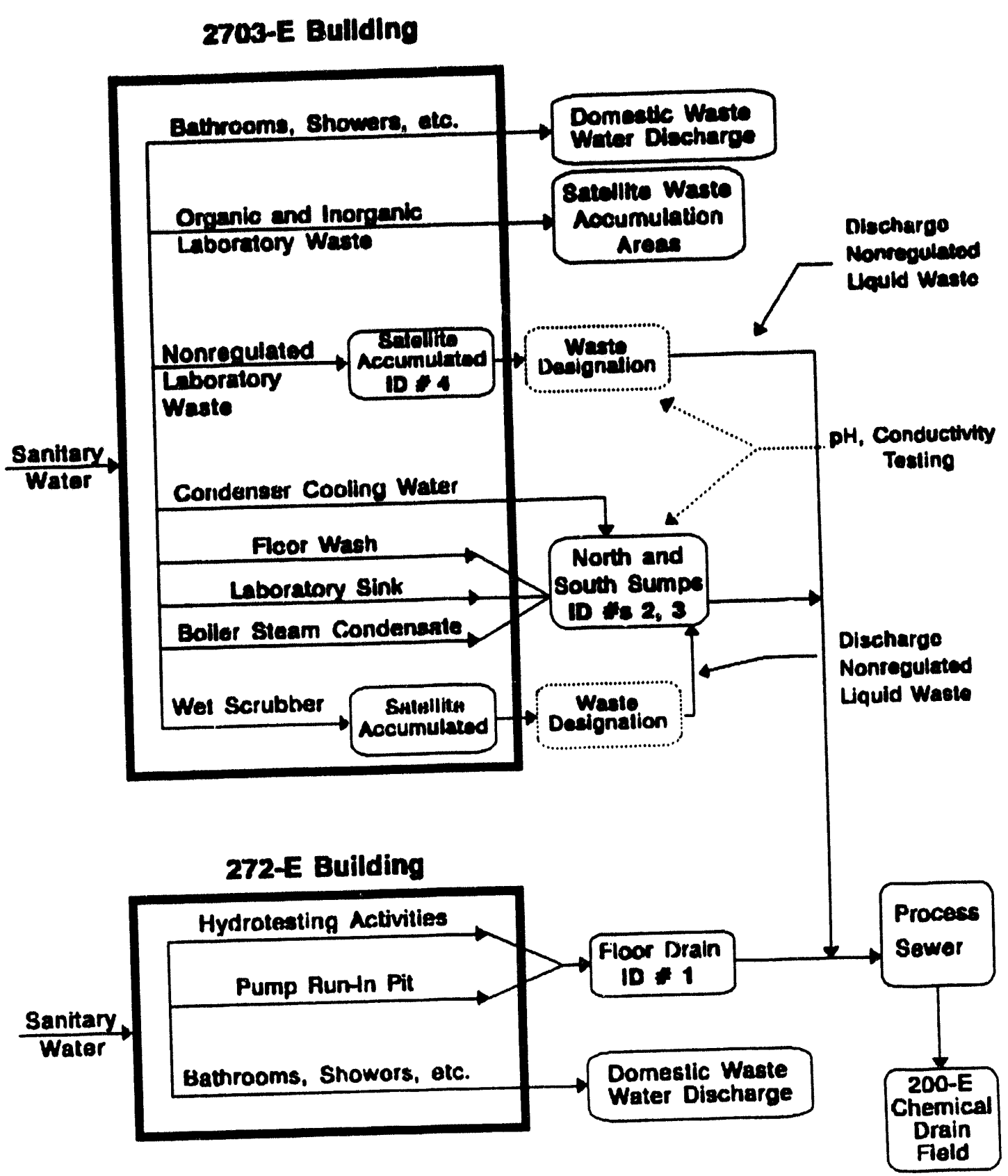

Figure C-1. Disposal Routes for Wastes Generated at the 272-E and 2703-E Buildings. 


\section{SECTION C, ITEM 6 \\ SRITE NNTORMATUONR \\ INTRODUCTION}

Shift information is slightly different for the 272-E Building than for the 2703-E

Building. Therefore, the shift information for each building is provided in the following:

12 272-E Personnel

13 Number of employees per shift:

Shift start times

14

15

1 st

23

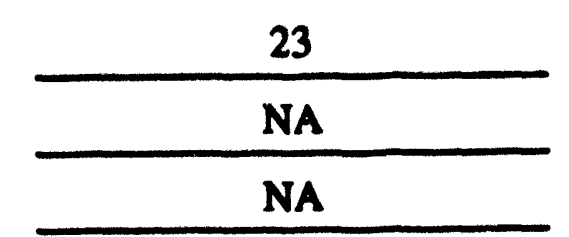

\begin{tabular}{ll} 
1st & 7:30 a.m. \\
3rd & NA \\
\cline { 2 - 2 }
\end{tabular}

16 3rd

2nd

NA

NA

18

19 2703-E Personnel

20 Number of employees per shift:

21

22

1 st

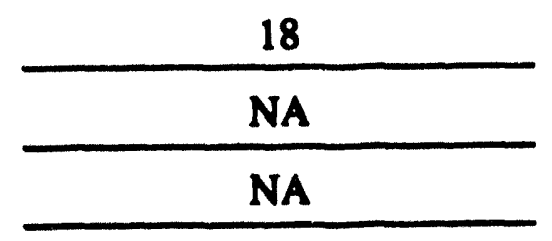

1

Shift start times

$\begin{array}{ll}\text { 1st } & \text { 7:00 a.m. } \\ \text { 3rd NA } & \text { NA }\end{array}$ 
DOE/RL-94-24, Rev, 0 $06 / 94$

200-E Chemical Drain Field

\begin{abstract}
1 SECTION C, ITEM 7
2

3 LIST ALL NCIDENTAL MATFRIALS UIKE OII. PANTT, GREASE, SOLVENTS,

4 SOAPS, CLFANITRS, THAT ARE USED OR STOR EXD ON SUTE.

The 272-E Building stores all incidental materials in five flammable material storage cabinets located inside the facility. Table C-1 provides a summary of all incidental materials and quantities stored in these 5 cabinets. The information summarized is current as of February, 1994. However, the 272-E Building incidental materials will vary over the course of a year.

The 2703-E Building stores chemicals in cabinets and on shelving inside the building and in a conex box located north of the building. The conex box is a pre-engineered, semipermanent metal storage container with wire shelving for chemical storage. There are no secondary containment structures or berms, and there is no floor drain. However, the chemicals stored in the conex box are in solid form and can be easily cleaned up in case of a spill. A summary of selected chemicals and other incidental materials and quantities stored in the 2703-E Building and conex box are given in Table C-2.

The information provided in these tables is based on a February 1994 assessment. The 2703-E Building is an experimental laboratory and the chemical inventory could vary slightly depending on the chemical needs of the activities being performed. The chemical inventory is updated as needed and a database containing the inventory is updated monthly.
\end{abstract}


Table C-1. Summary of Incidental Materials at the 272-E Building. (Sheet 1 of 1)

\begin{tabular}{|l|l|}
\hline \multicolumn{1}{|c|}{ PRODUCT } & \multicolumn{1}{c|}{ QUANTITY } \\
\hline Adhesive & 5.0 gallons \\
\hline Adhesive (solid) & 2.1 pounds \\
\hline Air freshener & $<5$ gallons \\
\hline Alcohol & 7.7 gallons \\
\hline Cleaner/degreaser & $<5$ gallons \\
\hline Cutting fluid & 8.4 gallons \\
\hline Enamel & $<5$ gallons \\
\hline Finish & $<5$ gallons \\
\hline Flux remover & $<5$ gallons \\
\hline Industrial coating & $<5$ gallons \\
\hline Ink & $<5$ gallons \\
\hline Lubricant & $<5$ gallons \\
\hline Lubricant (solid) & 31 pounds \\
\hline Oil & $<5$ gallons \\
\hline Paint & $<5$ gallons \\
\hline Pesticide & $<5$ gallons \\
\hline Primer & $<5$ gallons \\
\hline Sealant & $<5$ gallons \\
\hline Sealant (solid) & 5 pounds \\
\hline Solvent & $<5$ gallons \\
\hline Thinner & 5 gallons \\
\hline Varnish & $<5$ gallons \\
\hline
\end{tabular}


DOE/RL-94-24, Rev, 0

06/94

200-E Chemical Drain Field

Table C-2. Summary of Selected Chemicals and Other Incidental Materials at the 2703-E Building and the Conex Box.

(Sheet 1 of 9 )

\begin{tabular}{|c|c|}
\hline CHEMICALS / MATERIALS & QUANTITY \\
\hline 2 TBP/1 CMPO' & $<5$ gallons \\
\hline 2-(2-methoxyethoxy) ethanol & $<5$ gallons \\
\hline 2-butanone & $<5$ gallons \\
\hline 4-methyl-2-pentanone & $<5$ gallons \\
\hline Acetone & $<5$ gallons \\
\hline Air freshener & $<5$ gallons \\
\hline Alumina polishing powder & $<1$ pounds \\
\hline Aluminum chloride, anhydrous & 3.3 pounds \\
\hline Aluminum nitrate nonahydrate & 25.2 pounds \\
\hline Aluminum oxide & $<1$ pound \\
\hline Aluminum silicate hydroxide & 200 pounds \\
\hline Aluminum sulfate & $<1$ pound \\
\hline Ammonium carbonate & 16.5 pounds \\
\hline Ammonium chloride & $<1$ pound \\
\hline Ammonium hexafluorosilicate & 20.5 pounds \\
\hline Ammonium hydroxide & 8 pounds \\
\hline Ammonium moly sdate & 1.2 pounds \\
\hline Ammonium nitrate & 1 pound \\
\hline Ammonium nitrate solution & 8 gallons \\
\hline Ammonium sulfate anhydrous & 249 pounds \\
\hline Amyl acetate & $<5$ pounds \\
\hline Aquafix $^{2}$ & $<5$ pounds \\
\hline Barium chloride & 5.1 pounds \\
\hline Barium nitrate & 7.0 pounds \\
\hline
\end{tabular}

C-7 
DOE/RL-94-24, Rev, 0

06/94

200-E Chemical Drain Field

Table C-2. Summary of Selected Chemicals and Other Incidental Materials at the 2703-E Building and the Conex Box.

(Sheet 2 of 9 )

\begin{tabular}{|l|l|}
\hline CHEMCALS / MATERIALS & QUANTITY \\
\hline Barium sulfate & 20 pounds \\
\hline Bentonite & 150 pounds \\
\hline Bismuth nitrate & 15.2 pounds \\
\hline Boric acid & 52 pounds \\
\hline Boron trioxide & 35 pounds \\
\hline Calcium carbonate & 5 pounds \\
\hline Calcium chloride & 246 pounds \\
\hline Calcium fluoride & 5 pounds \\
\hline Calcium hypochlorite & 4.8 pounds \\
\hline Calcium nitrate & 18.2 pounds \\
\hline Calcium sulfate dihydrate & 2.2 pounds \\
\hline Cement & 100 pounds \\
\hline Ceric ammonium nitrate & 2.6 pounds \\
\hline Ceric oxide & 11 pounds \\
\hline Ceric sulfate & 1 pound \\
\hline Cerium dioxide & 1.5 pounds \\
\hline Cerous nitrate & 46.7 pounds \\
\hline Cesium carbonate & 1.5 pounds \\
\hline Cesium chloride & 11 pounds \\
\hline Cesium nitrate & 31 pounds \\
\hline Charcoal lighter fluid & $<5$ gallons \\
\hline Chloroform & 4.4 pounds \\
\hline Chromic sesquioxide & 5 pounds \\
\hline Chromium nitrate & 23.5 pounds \\
\hline & \\
\hline
\end{tabular}


DOE/RL-94-24, Rev, 0 06/94

200-E Chemical Drain Field

Table C-2. Summary of Selected Chemicals and Other Incidental Materials at the 2703-E Bullding and the Conex Box.

(Sheet 3 of 9)

\begin{tabular}{|l|l|}
\hline CHEMICALS / MATERIALS & QUANTITY \\
\hline Citric acid & 5.7 pounds \\
\hline Cleaner/degreaser & 135 pounds \\
\hline Cleaner/degreaser & $<5$ gallons \\
\hline CMPO & 4 pounds \\
\hline Cobalt(ous) nitrate & $<1$ pound \\
\hline Copper (ii) carbonate, basic & 1.1 pounds \\
\hline Copper (ii) nitrate, hemipentahydrate & 13.2 pounds \\
\hline Copper (ii) sulfate, anhydrous & 5.5 pounds \\
\hline Cupric carbonate & 2.0 pounds \\
\hline Cupric nitrate n-hydrate & $<1$ pound \\
\hline Cupric sulfate & 2.4 pounds \\
\hline Cyanex 272 Extract & $<5$ gallons \\
\hline Cyanex in n-dodecane & $<5$ gallons \\
\hline Delimer powder & 50 pounds \\
\hline Dichloromethane (methylene chloride) & $<5$ gallons \\
\hline Dodecane, 99 percent & 6.2 gallons \\
\hline Duolite CS-100 & 141 pounds \\
\hline EDTA & 17.3 pounds \\
\hline Ethylene glycol & 13.2 gallons \\
\hline Ferric chloride & $<1$ pound \\
\hline Ferric nitrate & 98 pounds \\
\hline Ferric nitrate nanohydrate & 14.1 pounds \\
\hline Ferric oxide & 34.2 pounds \\
\hline Ferric sulfate & 350 pounds \\
\hline & \\
\hline
\end{tabular}


DOE/RL-94-24, Rev, 0

06/94

200-E Chomical Drain Field

Table C-2. Summary of Selected Chemicals and Other Incidental Materials at the 2703-E Building and the Conex Box.

(Sheet 4 of 9 )

\begin{tabular}{|l|l|}
\hline CHEMICALS / MATERIALS & QUANTITY \\
\hline Ferrosoferric sulfate & $<5$ gallons \\
\hline Ferrous ammonium sulfate & 7.9 pounds \\
\hline Ferrous sulfate heptahydrate & 11.0 pounds \\
\hline Fluorescein disodium salt & $<1$ pound \\
\hline Glycerine & $<5$ gallons \\
\hline Glycerol & 15.1 gallons \\
\hline Glycolic acid & $<5$ gallons \\
\hline HEDPA', .1M & $<5$ gallons \\
\hline HEDTA & 8.6 pounds \\
\hline Hydrochloric acid, 38 percent & 11 pounds \\
\hline Hydrofluoric acid, 48 percent & 9 pounds \\
\hline Hydrofluorosilicic acid, 30 percent & $<5$ gallons \\
\hline Hydrogen peroxide, 50 percent & 4.5 gallons \\
\hline Hydrogen peroxide, 30 percent & $<5$ gallons \\
\hline Isopropyl alcohol & $<5$ gallons \\
\hline Lanthanum nitrate & 3.9 pounds \\
\hline Lead nitrate & 2.1 pounds \\
\hline Lime (calcium oxide) & 100 pounds \\
\hline Limestone (raw material) & 80 pounds \\
\hline Liquified petroleum & $<5$ gallons \\
\hline Lithium carbonate & 1 pound \\
\hline Lithium chloride & $<1$ pound \\
\hline Lithium hydroxide & 17 pounds \\
\hline Magnesium dioxide & 50 pounds \\
\hline & \\
\hline
\end{tabular}


DOE/RL-94-24, Rev, 0

06/94

200-E Chamical Drin Field

Table C-2. Summary of Selected Chemicals and Other Incidental Materials at the 2703-E Bullding and the Conex Box.

(Sheet 5 o( 9)

\begin{tabular}{|l|l|}
\hline CHEMCALS / MATERIALS & QUANTITY \\
\hline Magnesium nitrate, 6-hydrate & 97.1 pounds \\
\hline Magnesium oxide & 2.6 pounds \\
\hline Magnesium powder & 1.1 pounds \\
\hline Magnesium sulfate anhydrous & $<1$ pound \\
\hline Manganese dioxide & 15 pounds \\
\hline Manganese(ous) nitrate, 50 percent solution & 33.1 pounds \\
\hline Methanol & $<5$ gallons \\
\hline Methoxy triglycol & $<1$ pound \\
\hline Methylene blue & $<1$ pound \\
\hline Methylene chloride & $<5$ gallons \\
\hline Molybdenum (VI) oxide & 1.5 pounds \\
\hline Molybdic acid & 1 pound \\
\hline N,N-dimethyl-p-toluidine & $<5$ gallons \\
\hline N-butyl alcohol & $<5$ gallons \\
\hline N-hexane & 5.3 gallons \\
\hline N-nitrosodimethylamine/trichloroethane & $<5$ gallons \\
\hline N-tridecane, 99 percent & $<5$ gallons \\
\hline Neodymium nitrate & $<1$ pound \\
\hline Nickel (II) nitrate & $<1$ pound \\
\hline Nickel sulfate & 6.4 pounds \\
\hline Nitric acid, .2 M & $<5$ gallons \\
\hline Nitric acid, 70 percent & 84 pounds \\
\hline Normal paraffin hydrocarbon (NPH) & 18 gallons \\
\hline NPH from silica gel column & $<5$ gallons \\
\hline & \\
\hline
\end{tabular}


DOE/RL-94-24, Rev, 0

$06 / 94$

200-E Chemical Drin Field

Table C-2. Summary of Selected Chemicals and Other Incidental Materials at the 2703-E Building and the Conex Box.

(Sheet 6 of 9 )

\begin{tabular}{|l|l|}
\hline CHEMCALS / MATERIALS & QUANTITY \\
\hline Oil & 6 gallons \\
\hline Oxalic acid & 11 pounds \\
\hline Paint and epoxy remover & $<5$ gallons \\
\hline Phenol red, .1 percent & $<5$ gallons \\
\hline Phenolphthalein & $<1$ pound \\
\hline Phosphoric acid, 85 percent & 8 pounds \\
\hline Potassium bromate & 21 pounds \\
\hline Potassium bromide & 1 pounds \\
\hline Potassium carbonate & 68.5 pounds \\
\hline Potassium chloride & 3.0 pounds \\
\hline Potassium fluoride & 6.8 pounds \\
\hline Potassium fluoride anhydrous & $<1$ pound \\
\hline Potassium hydroxide & 40.4 pounds \\
\hline Potassium iodate & 1.1 pounds \\
\hline Potassium nitrate & 2.8 pounds \\
\hline Potassium permanganate & 1.5 pounds \\
\hline Potassium phosphate, dibasic & 24 pounds \\
\hline Potassium sulfate & 4.5 pounds \\
\hline Primer & $<5$ gallons \\
\hline Propylene glycol industrial & 55 gallons \\
\hline Rare earth nitrate & 55.5 gallons \\
\hline Rare earth nitrate & $<1$ pounds \\
\hline Rare earth nitrate, 25 percent solution & $<5$ gallons \\
\hline Red liquid food color & $<5$ gallons \\
\hline
\end{tabular}


DOE/RL-94-24, Rev, 0

$06 / 94$

200-E Chemical Drain Field

Table C-2. Summary of Selected Chemicals and Other Incidental Materials at the 2703-E Building and the Conex Box.

(Sheet 7 of 9)

\begin{tabular}{|l|l|}
\hline CHEMCALS / MATERIALS & QUANITIY \\
\hline Rubidium nitrate & $<1$ pound \\
\hline Ruthenium trichloride & $<1$ pound \\
\hline Silica, 30 percent in $\mathrm{H}_{2} \mathrm{O}$ & 28.6 pounds \\
\hline Silicon dioxide & 47 pounds \\
\hline Silver nitrate & 30 pounds \\
\hline Sodium acetate & 2.2 pounds \\
\hline Sodium aluminate & $<1$ pound \\
\hline Sodium aluminate (solution) & 14 gallons \\
\hline Sodium aluminate (solid) & 170 pounds \\
\hline Sodium bicarbonate & 3.1 pounds \\
\hline Sodium carbonate & 276.7 pounds \\
\hline Sodium chloride & 66 pounds \\
\hline Sodium chromate & $<1$ pound \\
\hline Sodium dichromate & 10.3 pounds \\
\hline Sodium ferrocyanide & 7.6 pounds \\
\hline Sodium fluoride & 16.7 pounds \\
\hline Sodium fluosilicate & $<1$ pound \\
\hline Sodium formate & 1.1 pounds \\
\hline Sodium hydroxide & 20.5 pounds \\
\hline Sodium hydroxide, 50 percent & $<5$ gallons \\
\hline Sodium hydroxide, $5 \mathrm{M}$ & 5 gallons \\
\hline Sodium metabisulfite & 10.5 pounds \\
\hline Sodium metasilicate & 33.1 pounds \\
\hline Sodium nitrate & 176.1 pounds \\
\hline & \\
\hline
\end{tabular}


DOE/RL-94-24, Rev, 0

$06 / 94$

200-E Chamical Drin Fiald

Table C-2. Summary of Selected Chemicals and Other Incidental Materials at the 2703-E Building and the Conex Box.

(Sheet 8 of 9 )

\begin{tabular}{|l|l|}
\hline CHEMICALS / MATERIALS & QUANTITY \\
\hline Sodium nitrite & 97.4 pounds \\
\hline Sodium orthosilicate & 2.2 pounds \\
\hline Sodium phosphate dibasic & 30 pounds \\
\hline Sodium phosphate monobasic & 12.8 pounds \\
\hline Sodium phosphate tribasic & 14 pounds \\
\hline Sodium silicate & $<5$ gallons \\
\hline Sodium sulfate & 87.5 pounds \\
\hline Soduim sulfide, 98.5 percent (assay) & 1.1 pounds \\
\hline Sodium sulfide, nonahydrate & 1.3 pounds \\
\hline Sodium sulfite & 3.2 pounds \\
\hline Sodium tetraborate decahydrate & 6.4 pounds \\
\hline Stannous chloride & 1.8 pounds \\
\hline Strontium fluoride & 5.7 pounds \\
\hline Strontium nitrate & 99 pounds \\
\hline Sucrose & 11.1 pounds \\
\hline Sulfamic acid & 4.4 pounds \\
\hline Sulfur & 51 pounds \\
\hline Sulfuric acid, 95 percent & 81 pounds \\
\hline Thinner-lacquer & $<5$ gallons \\
\hline Titanium dioxide & 31 pounds \\
\hline Toluene & $<5$ gallons \\
\hline Tributyl phosphate & 49 gallons \\
\hline Tridodecylamine & 1.7 pounds \\
\hline Ultragel II ultrasonic couplant ${ }^{10}$ & $<5$ gallons \\
\hline
\end{tabular}


DOE/RL-94-24, Rev, 0 $06 / 94$

200-E Chemical Drin Fiald

Table C-2. Summary of Selected Chemicals and Other Incidental Materials at the 2703-E Building and the Conex Box.

(Sheet 9 of 9)

\begin{tabular}{|l|l|}
\hline CHEMICALS / MATERIALS & QUANTITY \\
\hline Urea & 94 pounds \\
\hline Vanadium (V) oxide & $<1$ pound \\
\hline Xylene & $<5$ gallons \\
\hline Zinc chloride & 5.2 pounds \\
\hline Zinc nitrate & 13.2 pounds \\
\hline Zinc oxide & 50 pounds \\
\hline Zirconium (IV) phosphate & $<1$ pound \\
\hline Zirconium dinitrate oxide & 6.2 pounds \\
\hline Zirconium fluoride & $<1$ pound \\
\hline Zirconium nitrate & $<1$ pound \\
\hline Zirconium oxide & 14.0 pounds \\
\hline Zirconium sulfate & 4.6 pounds \\
\hline Zirconyl nitrate & $<1$ pound \\
\hline Zirconyl nitrate hydrate & 3.3 pounds \\
\hline
\end{tabular}

2 1 2 parts Tributyl Phosphate, 1 part Octy(Phenyl) -N,N-Diisobutyl -

3 carbamoylmethylphosphine Oxide

42 Aquafix is a trademark for Aquaair Environmental, Inc.

$5{ }^{3}$ Octy(Phenyl) -N,N-Diisobutyl - Carbamoylmethylphosphine Oxide

6 - Cyanex 272 Extract is a trademark of American Cyanamid Company.

7 is Cyanex in n-dodecane is a trademark of the Humphrey Chemical Company.

8 - Duolite CS-100 is a trademark of the Rohm and Haas Company.

97 Ethylenediamine tetraacetic acid.

10 - 1-hydroxyethane-1, 1-diphosphonic acid.

11 - Hydroxyethylethylene diaminetriacetic acid.

12 Ultragel II is a trademark of the Echo Ultrasound, Inc. 
DOE/RL-94-24, ReV, 0

$06 / 94$

200-B Chemical Drain Fiold

\section{SECTION C, ITEM 9}

2 Answers to items a through e are the same for both the 272-E and 2703-E Buildings.

4 However, the 272-E and 2703-E Buildings cach have a separate Emergency Response Plan. 
DOE/RL-94-24, Rev, 0

06/94

200-E Cremical Drain Field

\section{APPENDEX D}

WATER CONSUMPTION AND WATER LOSS

App D-i 
DOE/RL-94-24, Rev, 0

06/94

200-E Chemical Drain Fiald

1
2
3
4
5
6

This page intentionally left blank.

App D-ii 
DOE/RL-94-24, Rev, 0

$06 / 94$

200-B Chemical Drin Fiold

\section{CONTENTS}

\section{SECTION D, ITEM 3}

ATTACH A LINE DRAWING SHOWING THE WATER FLOW THROUGH THE FACIITY. INDICATE SOURCE OF INTAKE

WATER, OPERATIONS CONTRIBUTING WASTE WATER TO THE

EFFLUENT, AND TREATMENT UNITS LABELED TO CORRESPOND

TO THE MORE DETAILED DESCRIPTIONS IN ITEM C.

CONSTRUCT A WATER BALANCE ON THE LINE DRAWING BY

SHOWING AVERAGE FLOWS BETWEEN INTAKES, OPERATIONS, TREATMENT UNITS, AND OUTFALLS. IF A WATER BALANCE

CANNOT BE DETERMINED (E.G., FOR CERTAIN MINING

ACTIVTTIES), PROVIDE A PICTORIAL DESCRIPTION OF THE

NATURE AND AMOUNT OF ANY SOURCES OF WATER AND

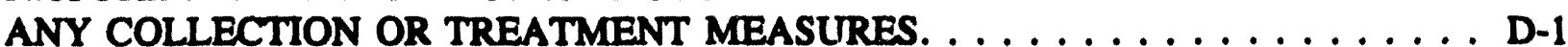

\section{EIGURE}

D-1 Water Flow Diagram for the 272-E and 2703-E Buildings. . . . . . . . D-3 
DOE/RL-94-24, Rev, 0

06/94

200-E Chemical Drein Field

This page intentionally left blank. 
DOE/RL-94-24, Rev, 0

06/94

200-E Chemical Drain Field

1 SECTION D, ITEM 3

2

Figure D-1 is a line drawing showing the water flow through the 272-E and 2703-E Buildings. Sanitary water from the 283-E Water Treatment Facility is supplied to both buildings for use in the laboratory area of the 2703-E Building, the shop area of the 272-E Building, and the bathrooms and kitchens of both buildings. The figure shows the waste water generated in each building and the corresponding disposal route to either the 200-E Chemical Drain Field, a domestic waste water discharge system, or other waste accumulation areas. Flow measurements for the effluent discharged to the 200-E Chemical Drain Field are indicated on the figure in gallons per minute.

Testing activities in the 272-E Building are performed in batches and create an intermittent flow of waste water to the 200-E Chemical Drain Field. The 272-E Building discharges an average of 0.113 gallons per minute to the 200-E Chemical Drain Field. This volume was based on averaging estimates of water used during hydrotesting and pump testing activities.

The pipes tested during hydrotesting activities range from $1 / 2$ inch to 3 inches in diameter and the testing process for each pipe uses anywhere from 20 to 200 gallons of sanitary water. Estimates on the amount of waste water generated vary with a maximum average of $\mathbf{5 0}$ gallons per hydrotest. Tests are conducted six to seven times per month. Based on seven hydrotests performed per month using 50 gallons per test, 4,200 gallons of waste water are generated per year.

During pump tests, the pump run-in pit is filled approximately $1 / 2$ to $3 / 4$ full with sanitary water. A pump test is conducted every three to four months. Based on the pit being filled to $3 / 4$ capacity and four pump tests being conducted four times a year, approximately 55,200 gallons of water per year are discharged to the process sewer line through the floor drains from the testing of pump assemblies. 
1 The 2703-E Building discharges 0.202 gallons per minute to the 200-E Chemical Drain 2 Field. This volume includes waste discharged from the sumps and nonregulated waste

3 discharged via the sumps to the process sewer lines. The discharge volume from the 2703-E

4 Building is based on an average of the total amount of waste water discharged annually from

51991 to 1993. The number of gallons discharged per year for the years 1991, 1992, and

61993 were 12, 550 gallons, 41,015 gallons, and 52,935 galions, respectively. The average

7 flow rate in gallons per year was converted to gallons per minute (assuming 365 days per

8 year, 24 hours per day, and 60 minutes per hour). 
DOE/RL-94-24, Rev. 0

06/94

200-E Chemical Drain Field

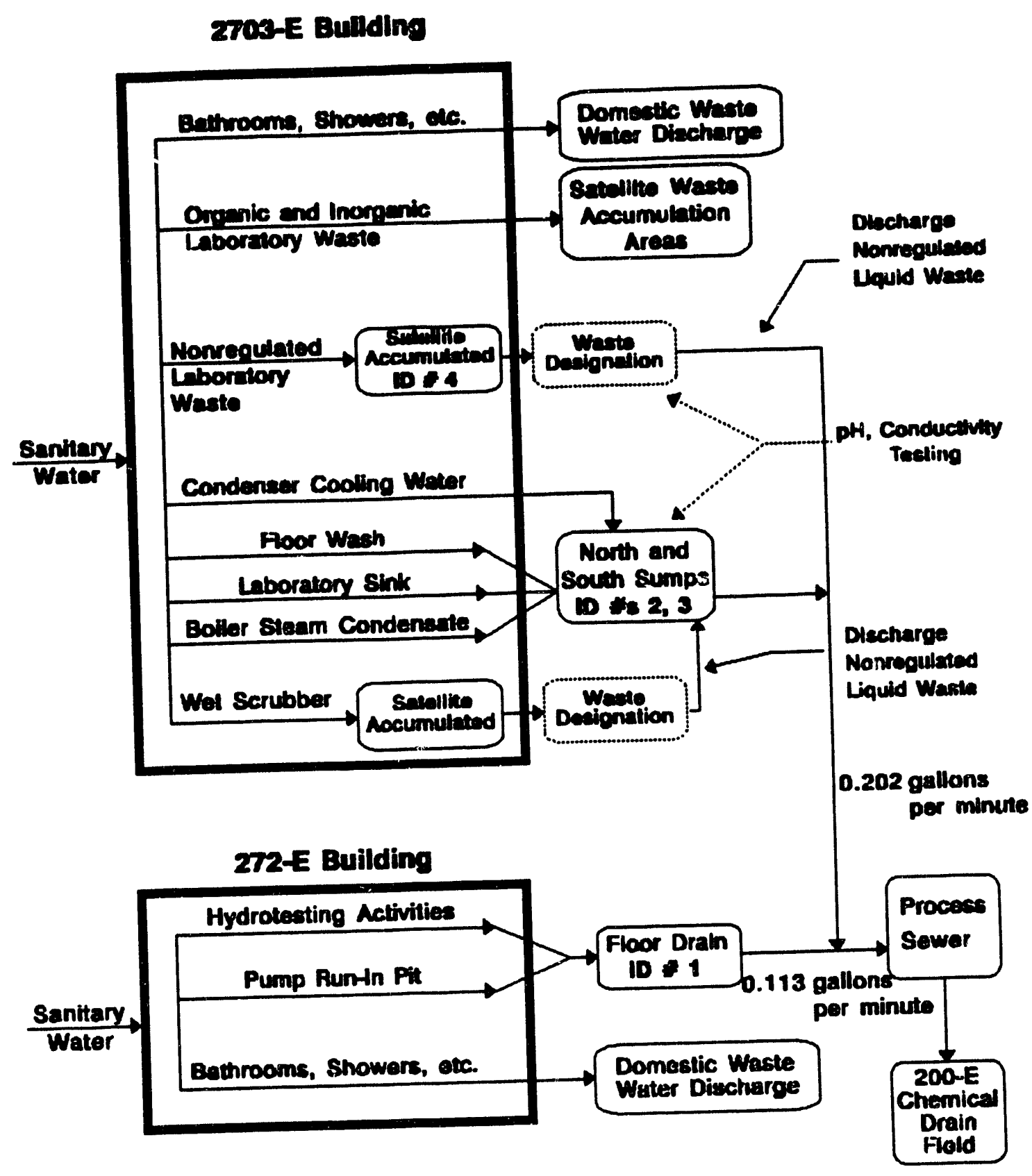

Figure D-1. Water Flow Diagram for the 272-E and 2703-E Buildings. 
DOE/RL-94-24, Rev. 0

06/94

200-E Chomical Drain Field

1

2

3

4

5

6

This page intentionally left blank.

D-4 
DOE/RL-94-24, Rev. 0

06/94

200-E Chemical Drain Field

APPENDX E

WASTE WATER INFORMATION

App E-i 
DOE/RL-94-24, Rev. 0

06/94

200-E Chemical Drain Field

1
2
3
4
5
6

This page intentionally left blank.

App E-ii 
DOE/RL-94-24, Rev. 0 $06 / 94$

200-E Chomical Drin Fiold

\section{CONTENTS}

\section{SECTION E, ITEM 1}

PROVIDE MEASUREMENTS FOR TREATED WASTE WATER

PRIOR TO LAND APPLICATION FOR THE PARAMETERS LISTED

BELOW, UNLESS WAIVED BY THE PERMITTING AUTHORITY.

ALL ANAL YTICAL METHODS USED TO MEET THESE

REQUIREMENTS SHALL, UNLESS APPROVED OTHERWISE IN

WRITING BY ECOLOGY, CONFORM TO THE GUIDELINES

ESTABLISHING TEST PROCEDURES FOR THE ANALYSIS OF

POLLUTANTS CONTANNED IN 40 CER PART 136. . . . . . . . . E E-1

\section{TABLES}

E-1 2703-E Building Waste Water Effluent Data $\ldots \ldots \ldots \ldots \ldots \ldots \ldots$ E-2

E-2 272-E Building Waste Water Effluent Data $\ldots \ldots \ldots \ldots \ldots \ldots \ldots \ldots$ E-6 
DOE/RL-94-24, Rev. 0

06/94

200-E Chemical Drain Fiold

This page intentionally left blank. 
22

\section{SECTION E, ITEM 1}

\section{BROVIDE MTA GUR WMINTS FOR TREATTDO WASTE WATER PRIOR TO LAND APPITCATION BOR THE PARAMTETERS IISTEDD BETOW, UNTLSS WATVED BY

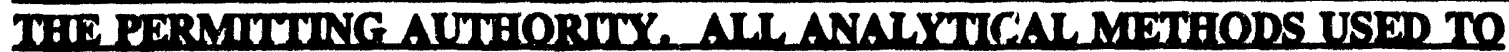

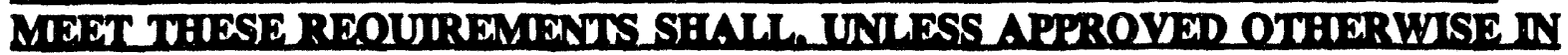 WRRUING BY FCO LOGY. CONTORM TO THE GUIDELINES ESTABL LISHING TEST BROCEDURES FOR THE ANALYSIS OE POULUTANTS CONTAINED IN 40 CER PART 136.}

The samples and resultant data presented below were obtained in accordance with a sampling and analysis plan (WHC 1993c). Data has been provided for the waste water from two different buildings since both are disposed of in the 200-E Chemical Drain Field. The data from the two buildings were not combined because of the intermittent and variable nature of the flow. The data for the 272-E Building waste water was obtained from a maintenance hole (MHP1E) which accesses the chemical sewer line just outside of the building. The data for the 2703-E Building waste water was obtained from the floor sump just prior to the regularly scheduled weekly draining. The data confirm the available process knowledge that indicate the constituent concentrations are generally consistent with typical waste water streams as discussed in Metcalf and Eddy (1991) and the EPA design manual (EPA 1980).

Only two constituents, Bis (2-ethylhexyl) phthalate and iron, were found in excess of the WAC-173-200 Ground Water Quality Criteria (GWQC). The phthalate compound was found in the 272-E Building waste water sample at a level of $20 \mathrm{ug} / \mathrm{L}$ and in the 2703-E Building waste water sample at a level of $110 \mathrm{ug} / \mathrm{L}$.

Pthalates are common in plastics, oils and greases, so it is possible that the compound is in the waste water. However, because of their ubiquitous nature, the pthalates may have been introduced inadvertantly by the samplers and/or the laboratory. 
DOE/RL-94-24, Rev. 0

Table E-1. 2703-E Building Waste Water Emuent Data. Sheet 1 of 4

\begin{tabular}{|c|c|c|c|c|c|c|}
\hline \multicolumn{7}{|c|}{ EFFLUENT } \\
\hline CONSTIIUEATI & $n$ & $\begin{array}{l}\text { MEAN } \\
\text { CONC. }\end{array}$ & S.D. & UNmS & METEOD & D.L: \\
\hline \multicolumn{7}{|c|}{ Waste Water Parameters d } \\
\hline Conductivity & 2 & 349 & 2 & umho/cm & 120.1 & 6 \\
\hline $\mathrm{pH}$ & 2 & $7.2(\mathrm{~J} 2)$ & 0.1 & $\mathrm{pH}$ & 9040 & 0.1 \\
\hline TDS & 2 & 208 & 3 & $\mathrm{mg} / \mathrm{L}$ & 160.1 & 5 \\
\hline TSS & 2 & 17.5 & 2.1 & $\mathrm{mg} / \mathrm{L}$ & 160.2 & 5 \\
\hline Total Phosphorous & 2 & $0.13(\mathrm{~J} 2)$ & 0.02 & $\mathrm{mg} / \mathrm{L}$ & 365.2 & 0.05 \\
\hline Total Oil and Grease & 2 & $5(U)$ & N/A & $\mathrm{mg} / \mathrm{L}$ & 9070 & 5 \\
\hline \multicolumn{7}{|l|}{ Metals } \\
\hline $\mathrm{Ca}$ & 2 & 22300 & N/A & ug/L & 6010 & $10(\mathrm{P})$ \\
\hline $\mathbf{M g}$ & 2 & 6565 & 21 & $\mathrm{ug} / \mathrm{L}$ & 6010 & $30(P)$ \\
\hline $\mathrm{Na}$ & 2 & 28550 & 495 & $\mathrm{ug} / \mathrm{L}$ & 6010 & $29(\mathrm{P})$ \\
\hline $\mathbf{K}$ & 2 & 12500 & 141 & $\mathrm{ug} / \mathrm{L}$ & 6010 & N/A \\
\hline $\mathrm{Cd}$ & 2 & 1.7 (U2) & N/A & $\mathrm{ug} / \mathrm{L}$ & 6010 & 1.7 \\
\hline $\mathrm{Cr}$ & 2 & $9.2(\mathrm{~B} 1)$ & 2.0 & $\mathrm{ug} / \mathrm{L}$ & 6010 & 2.5 \\
\hline $\mathrm{Pb}$ & 2 & $11.2(\mathrm{~B}, \mathrm{U})$ & 0.1 & $\mathrm{ug} / \mathrm{L}$ & 6010 & 11.1 \\
\hline $\mathrm{Hg}$ & 2 & $0.10(\mathrm{U} 2)$ & N/A & $u g / L$ & 7470 & 0.10 \\
\hline $\mathrm{Se}$ & 2 & 32.8 (U2) & N/A & $\mathrm{ug} / \mathrm{L}$ & 6010 & 33 \\
\hline $\mathrm{Ag}$ & 2 & 2.7 (B2) & 0.1 & $\mathrm{ug} / \mathrm{L}$ & 6010 & $7(P)$ \\
\hline $\mathrm{Cu}$ & 2 & 153 & N/A & $\mathrm{ug} / \mathrm{L}$ & 6010 & $6(P)$ \\
\hline $\mathrm{Fe}$ & 2 & 548 & 71 & $u g / L$ & 6010 & 7 (P) \\
\hline $\mathrm{Mn}$ & 2 & 40.2 & 0.6 & $\mathrm{ug} / \mathrm{L}$ & 6010 & $2(P)$ \\
\hline $\mathrm{Zn}$ & 2 & 252.5 & 2.1 & $\mathrm{ug} / \mathrm{L}$ & 6010 & $2(P)$ \\
\hline $\mathrm{Ba}$ & 2 & $41.3(\mathrm{~B} 2)$ & N/A & $\mathrm{ug} / \mathrm{L}$ & 6010 & $2(\mathrm{P})$ \\
\hline As & 2 & 15.6 (U2) & N/A & $\mathrm{ug} / \mathrm{L}$ & 6010 & 15.6 \\
\hline
\end{tabular}


DOE/RL-94-24, Rev. 0 06/94

200-E Chomical Drain Field

Table E-1. 2703-E Bullding Waste Water Emuent Data. Sheet 2 of 4

\begin{tabular}{|c|c|c|c|c|c|c|}
\hline \multicolumn{7}{|c|}{ EFRLUENT: } \\
\hline concrumuere & n & $\begin{array}{l}\text { MEAN } \\
\text { CONC. }\end{array}$ & Sp. & UNIIS & METHOD' & D.L. \\
\hline \multicolumn{7}{|l|}{ Anions } \\
\hline Fi & 2 & 2.6 & 0.1 & $\mathrm{mg} / \mathrm{L}$ & 300.0 & $0.1-0.2$ \\
\hline $\mathrm{Cl}^{-}$ & 2 & 14.5 & 0.9 & $\mathrm{mg} / \mathrm{L}$ & 300.0 & $0.2-0.4$ \\
\hline SO4= & 2 & 42 & 1 & $\mathrm{mg} / \mathrm{L}$ & 300.0 & $1-2$ \\
\hline $\mathrm{NO}_{2}^{-}, \mathrm{NO}_{3}^{-}$ & 4 & $5(U)$ & N/A & $\mathrm{mg} / \mathrm{L}$ & 353.2 & 5 \\
\hline \multicolumn{7}{|l|}{ Screening } \\
\hline TOC & 2 & $10.5(\mathrm{~J} 2)$ & 0.7 & $\mathrm{mg} / \mathrm{L}$ & 9060 & 1 \\
\hline TOX & 2 & 213 & 129 & $u g / L$ & 9020 & $\begin{array}{l}10.0 \\
20.0\end{array}$ \\
\hline \multicolumn{7}{|l|}{ Organies } \\
\hline Chloroform (VOC) & 1 & $1(\mathrm{~J})$ & N/A & $\mathrm{ug} / \mathrm{L}$ & 8240 & 5 \\
\hline $\begin{array}{l}\text { Methylene Chloride } \\
\text { (VOC) }\end{array}$ & 3 & $1(\mathrm{~J} 3)$ & N/A & ug/L & 8240 & 5 \\
\hline $\begin{array}{l}\text { Chloromethane } \\
\text { (VOC) }\end{array}$ & 2 & $1.5(\mathrm{~J} 2)$ & 0.7 & $u g / L$ & 8240 & 10 \\
\hline $\begin{array}{l}\text { TIC - Unknown } \\
\text { Hydrocarbon (VOC) }\end{array}$ & 1 & $2.73(\mathrm{~J})$ & N/A & ug/L & 8240 & N/A \\
\hline $\begin{array}{l}\text { TIC - Unknown } \\
\text { Hydrocarbon (VOC) }\end{array}$ & 1 & $2.73(\mathrm{~J})$ & N/A & $u g / L$ & 8240 & N/A \\
\hline $\begin{array}{l}\text { TIC - Unknown } \\
\text { Hydrocarbon (VOC) }\end{array}$ & N/A & N/A & N/A & ug/L & 8240 & N/A \\
\hline $\begin{array}{l}\text { TIC - Unknown } \\
\text { Hydrocarbon (VOC) }\end{array}$ & 1 & $11.89(\mathrm{~J})$ & N/A & $\mathrm{ug} / \mathrm{L}$ & 8240 & N/A \\
\hline $\begin{array}{l}\text { TIC - Unknown } \\
\text { Hydrocarbon (VOC) }\end{array}$ & 1 & $15.80(\mathrm{~J})$ & N/A & ug/L & 8240 & N/A \\
\hline $\begin{array}{l}\text { TIC - Unknown } \\
\text { Hydrocarbon (VOC) }\end{array}$ & 1 & $16.12(\mathrm{~J})$ & N/A & ug/L & 8240 & N/A \\
\hline
\end{tabular}


DOE/RL-94-24, Rev. 0

06/94

200-E Chemical Drain Field

Table E-1. 2703-E Building Waste Water Emuent Data.

Sheet 3 of 4

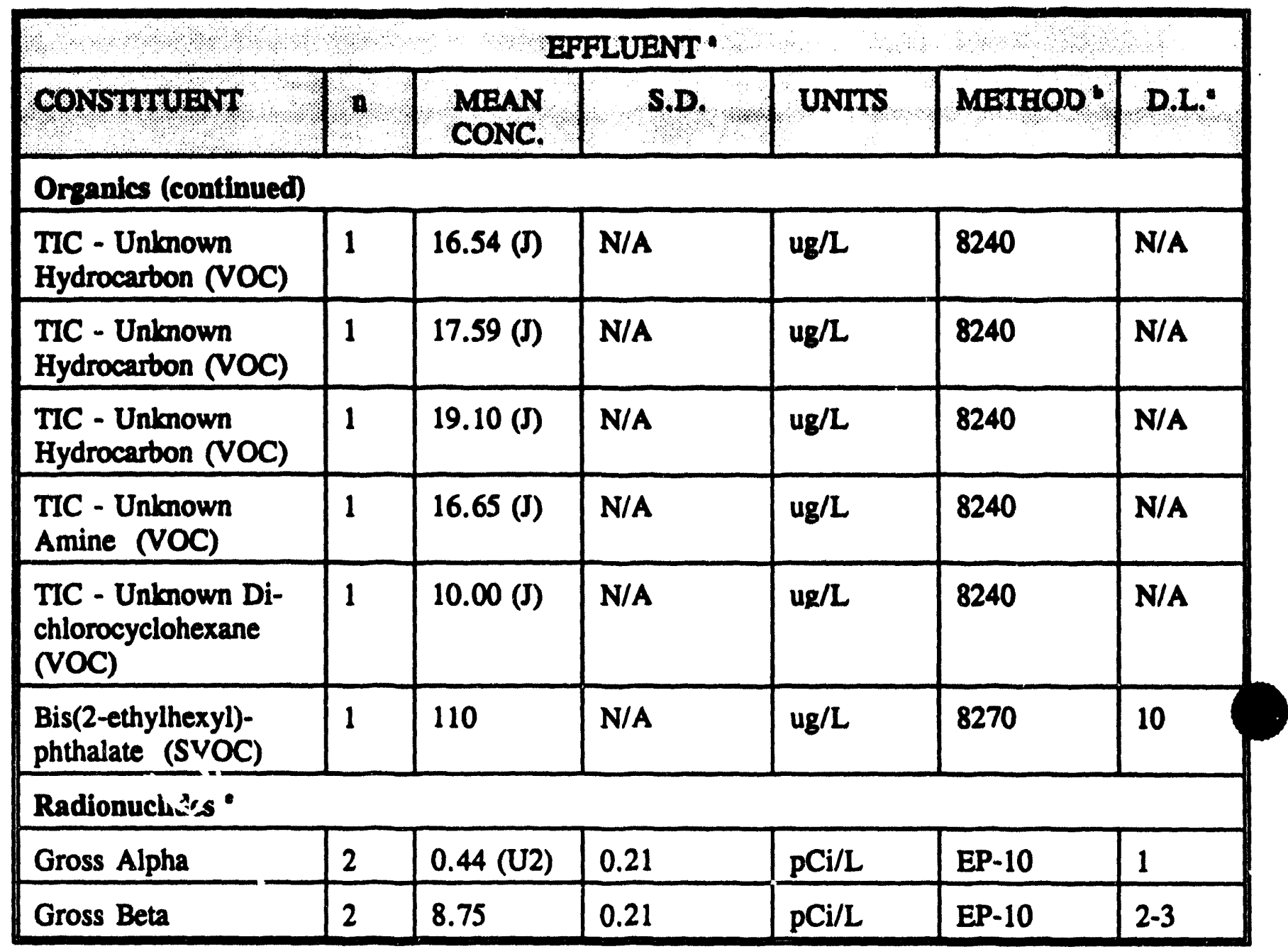




\section{Table E-1. 2703-E Bullding Waste Water Emuent Data.} Sheet 4 of 4

\author{
BOD = Biological Oxygen Demand \\ PAH = Polycyclic Aromatic Hydrocarbons \\ SVOC = Semi-Volatile Organic Compound \\ TDS = Total Dissolved Solids \\ TIC = Tenatively Identified Compound \\ $T K N=$ Total Kjeldahl Nitrogen \\ TOC $=$ Total Organic Carbon \\ TOX $=$ Total Organic Halide \\ TSS = Total Suspended Solids \\ VOC $=$ Volatile Organic Compound
}

mg/L = milligram er liter

pCill = picocuries piter

ug/L = micrograms per liter

umho/cm = micromhos per centimeter

N/A = Not Applicable

ND $=$ Not Detected

a $\quad n=$ Number of sample results averaged. mean conc $=$ mean concentration S.D. = one standard deviation about the mean

b Three digit numbers with a decimal (i.e. 120.1, 300.0 etc.) are from EPA 1979. Four digit procedure numbers (i.e. 6010, 9131 etc.) are from EPA 1992. Four digit numbers with a letter following (i.e., 5210B) are from "Standard Methods for the Examination of Water and Wastewater", 18th Edition, (APHA, 1992).

c D.L. detection level as reported by the laboratory or procedures (P) if no D.L. was reported with the data.

d Qualifiers which may appear in this table are:

(U) - Indicates the compound or analyte was analyzed for and not detected in the sample. The value reported is the sample quantitation limit (D.L.) corrected for sample dilution by the laboratory.

(J) - Indicates the compound or analyte was analyzed for and detected, but due to a QC deficiency identified during data validation, the associated quantitation limit is an estimate. This flag is also used when estimating concentrations of TICs or when the presence of a target compound is confirmed at a concentration of less than the D.L. but greater than the instrument detection limit.

(B) - This flag applies to results in which the analyte was detected in both the sample and the associated blank. For the metals, (B) also indicates the analyte concentration is less than the D.L. but greater than the instrument detection level.

Data qualifiers may appear in combinations. An alpha numeric combination (i.e., $\mathrm{U} 2$ ) indicates that two of the sample results used in the mean had a (U) qualifier. Two qualifiers separated by a comma (i.e., B,U) indicates that one of the samples in the mean has a (B) qualifier and one has a (U) qualifier.

e Contractor internal laboratory procedures are used for radiochemical analysis. 
DOE/RL-94-24, Rev. 0

06/94

200-E Chemical Drain Field

Table E-2. 272-E Building Waste Water Emuent Data. Sheet 1 of 4

\begin{tabular}{|c|c|c|c|c|c|c|}
\hline \multicolumn{7}{|c|}{ EFFLUENT" } \\
\hline CONSTIIUUENT & n & $\begin{array}{l}\text { MEAN } \\
\text { CONC. }\end{array}$ & S.D. & UNIIS & METHOD ${ }^{\circ}$ & D.L. \\
\hline \multicolumn{7}{|c|}{ Waste Water Parameters d } \\
\hline Conductivity & 2 & 122.5 & 0.7 & umho/ $\mathrm{cm}$ & 120.1 & 6 \\
\hline $\mathrm{pH}$ & 2 & $7.6(\mathrm{~J} 2)$ & 0.1 & $\mathrm{pH}$ & 9040 & 0.1 \\
\hline TDS & 2 & 74 & N/A & $\mathrm{mg} / \mathrm{L}$ & 160.1 & 5 \\
\hline TSS & 2 & $5.5(\mathrm{U} 2)$ & N/A & $\mathrm{mg} / \mathrm{L}$ & 160.2 & 5.5 \\
\hline Total Phosphorous & 2 & 0.05 (U2) & N/A & $\mathrm{mg} / \mathrm{L}$ & 365.2 & 0.05 \\
\hline Total Oil and Grease & 2 & $5(U 2)$ & N/A & $\mathrm{mg} / \mathrm{L}$ & 9070 & 5 \\
\hline \multicolumn{7}{|l|}{ Metals } \\
\hline $\mathrm{Ca}$ & 2 & $15900(\mathrm{~J} 2)$ & 283 & $\mathrm{ug} / \mathrm{L}$ & 6010 & $10(P)$ \\
\hline $\mathbf{M g}$ & 2 & 3675 (J2) & 92 & $\mathrm{ug} / \mathrm{L}$ & 6010 & $30(\mathrm{P})$ \\
\hline $\mathrm{Na}$ & 2 & $2230(\mathrm{~J} 2)$ & 57 & $u g / L$ & 6010 & 29 (P) \\
\hline $\mathbf{K}$ & 2 & $645.5(\mathrm{~B} 2)$ & 6.4 & $\mathrm{ug} / \mathrm{L}$ & 6010 & N/A \\
\hline $\mathrm{Cd}$ & 2 & 2.7 (U2) & 0.6 & $\mathrm{ug} / \mathrm{L}$ & 6010 & 2.7 \\
\hline $\mathrm{Cr}$ & 2 & $2.5(\mathrm{U} 2)$ & N/A & $\mathrm{ug} / \mathrm{L}$ & 6010 & 2.5 \\
\hline $\mathrm{Pb}$ & 2 & 17.9 (B2) & 2.3 & $\mathrm{ug} / \mathrm{L}$ & 6010 & 11.1 \\
\hline $\mathrm{Hg}$ & 2 & 0.10 (U2) & N/A & $u g / L$ & 7470 & 0.1 \\
\hline Se & 2 & 32.8 (U2) & N/A & $\mathrm{ug} / \mathrm{L}$ & 6010 & 33 \\
\hline $\mathrm{Ag}$ & 2 & 2.1 (U2) & N/A & $\mathrm{ug} / \mathrm{L}$ & 6010 & 2.1 \\
\hline $\mathrm{Cu}$ & 2 & 9.85 (U2) & 0.21 & $\mathrm{ug} / \mathrm{L}$ & 6010 & 10 \\
\hline $\mathrm{Fe}$ & 2 & 174 & 11 & $\mathrm{ug} / \mathrm{L}$ & 6010 & $7(\mathrm{P})$ \\
\hline $\mathrm{Mn}$ & 2 & 39.2 & 0.2 & $\mathrm{ug} / \mathrm{L}$ & 6010 & $2(P)$ \\
\hline $\mathrm{Zn}$ & 2 & 980.5 & 0.7 & $\mathrm{ug} / \mathrm{L}$ & 6010 & $2(P)$ \\
\hline $\mathrm{Ba}$ & 2 & 35.6 (B2) & 0.6 & $\mathrm{ug} / \mathrm{L}$ & 6010 & $2(\mathrm{P})$ \\
\hline As & 2 & 15.6 (U2) & N/A & ug/L & 6010 & 15.6 \\
\hline
\end{tabular}


DOE/RL-94-24, Rev. 0

06/94

200-E Chemical Drain Field

Table E-2. 272-E Building Waste Water Efmuent Data.

Sheet 2 of 4

\begin{tabular}{|c|c|c|c|c|c|c|}
\hline Eorvinguary & n & 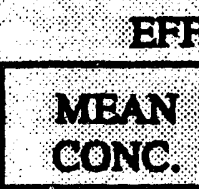 & 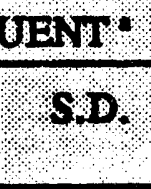 & UNITS & METHOD & D.t. \\
\hline \multicolumn{7}{|l|}{ Anions } \\
\hline $\mathbf{F l}^{-}$ & 2 & 0.1 (U2) & N/A & $\mathrm{mg} / \mathrm{L}$ & 300.0 & 0.1 \\
\hline $\mathrm{Cl}^{-}$ & 2 & 2.75 & 0.07 & $\mathrm{mg} / \mathrm{L}$ & 300.0 & 0.2 \\
\hline $\mathrm{SO}_{4}=$ & 2 & 12 & N/A & $\mathrm{mg} / \mathrm{L}$ & 300.0 & 1 \\
\hline $\mathrm{NO}^{*}$, $\mathrm{NO}^{-}$ & 3 & 0.25 (U3) & N/A & $\mathrm{mg} / \mathrm{L}$ & 353.2 & 0.25 \\
\hline \multicolumn{7}{|l|}{ Screening } \\
\hline TOC & 2 & 1.4 & N/A & $\mathrm{mg} / \mathrm{L}$ & 9060 & 1 \\
\hline TOX & 2 & 54 & 21 & $u g / L$ & 9020 & 10.0 \\
\hline \multicolumn{7}{|l|}{ Organics } \\
\hline Chloroform (VOC) & 2 & 5 & N/A & $\mathrm{ug} / \mathrm{L}$ & 8240 & 5 \\
\hline $\begin{array}{l}\text { Methylene Chloride } \\
\text { (VOC) }\end{array}$ & 1 & 1 (J) & N/A & $u g / L$ & 8240 & 5 \\
\hline $\begin{array}{l}\text { TIC - Unknown Alcohol } \\
\text { (VOC) }\end{array}$ & 1 & $4.8(J)$ & N/A & $u g / L$ & 8240 & N/A \\
\hline $\begin{array}{l}\text { TIC - Unknown Alcohol } \\
\text { (VOC) }\end{array}$ & 1 & $4.8(\mathrm{~J})$ & N/A & $u g / L$ & 8240 & N/A \\
\hline $\begin{array}{l}\text { TIC - Unknown Alcohol } \\
\text { (VOC) }\end{array}$ & 1 & $16(J)$ & N/A & ug/L & 8240 & N/A \\
\hline $\begin{array}{l}\text { TIC - Butyl- } \\
\text { Benzenesulfonamide } \\
\text { (VOC) }\end{array}$ & 1 & $19(\mathrm{JN})$ & N/A & ug $/ \mathrm{L}$ & 8240 & N/A \\
\hline $\begin{array}{l}\text { TIC - Unknown } \\
\text { Hydrocarbon (VOC) }\end{array}$ & 1 & $5(\mathrm{~J})$ & N/A & $u g / L$ & 8240 & N/A \\
\hline $\begin{array}{l}\text { TIC - Unknown } \\
\text { Hydrocarbon (VOC) }\end{array}$ & 1 & $8(J)$ & N/A & $u g / L$ & 8240 & N/A \\
\hline $\begin{array}{l}\text { TIC - Unknown } \\
\text { Hydrocarbon (VOC) }\end{array}$ & 1 & $5(\mathrm{~J})$ & N/A & $u g / L$ & 8240 & N/A \\
\hline
\end{tabular}


DOE/RL-94-24, Rev. 0

06/94

200-E Chemical Drain Field

Table E-2. 272-E Building Waste Water Emuent Data.

Sheet 3 of 4

\begin{tabular}{|c|c|c|c|c|c|c|}
\hline \multicolumn{7}{|c|}{ 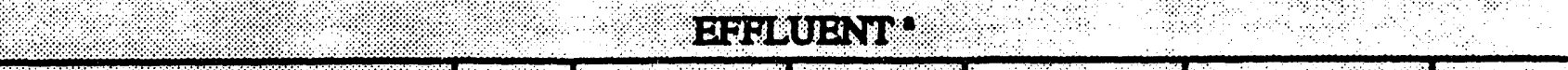 } \\
\hline 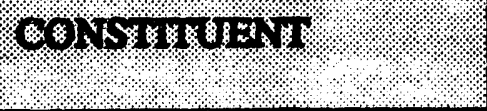 & a. & $\begin{array}{l}\text { MENir } \\
\text { CONC. }\end{array}$ & SDP. & UNIIS & METHOD & B.L. \\
\hline \multicolumn{7}{|l|}{ Organies (continued) } \\
\hline $\begin{array}{l}\text { TIC - Unknown } \\
\text { Hydrocarbon (VOC) }\end{array}$ & 1 & $7(J)$ & N/A & $\mathrm{ug} / \mathrm{L}$ & 8240 & N/A \\
\hline $\begin{array}{l}\text { TIC - Uninown } \\
\text { Hydrocarbon (VOC) }\end{array}$ & 1 & $12(J)$ & N/A & ug/L & 8240 & N/A \\
\hline $\begin{array}{l}\text { TIC - Unknown } \\
\text { Hydrocarbon (VOC) }\end{array}$ & 1 & $12(J)$ & N/A & ug/L & 8240 & N/A \\
\hline $\begin{array}{l}\text { TIC - Unknown } \\
\text { Hydrocarbon (VOC) }\end{array}$ & 1 & $12(J)$ & N/A & ug/L & 8240 & N/A \\
\hline $\begin{array}{l}\text { TIC - Unknown } \\
\text { Hydrocarbon (VOC) }\end{array}$ & 1 & $16(J)$ & N/A & ug/L & 8240 & N/A \\
\hline $\begin{array}{l}\text { TIC - Unknown } \\
\text { Hydrocarbon (VOC) }\end{array}$ & N/A & N/A & N/A & ug/L & 8240 & N/A \\
\hline $\begin{array}{l}\text { TIC - Unknown Di- } \\
\text { chlorocyclohexane (VOC) }\end{array}$ & N/A & N/A & N/A & ug $/ L$ & 8240 & N/A \\
\hline $\begin{array}{l}\text { Bis(2-ethylhexyl)phthalate } \\
\text { (SVOC) }\end{array}$ & 1 & 20 & N/A & ug/L & 8270 & 10 \\
\hline \multicolumn{7}{|l|}{ Radionuclides ${ }^{\circ}$} \\
\hline Gross Alpha & 2 & -0.04 (U2) & 0.30 & $\mathrm{pCi} / \mathrm{L}$ & EP-10 & 1 \\
\hline Gross Beta & 2 & 0.93 & 0.81 & $\mathrm{pCi} / \mathrm{L}$ & EP-10 & 2 \\
\hline
\end{tabular}


Table E-2. 272-E Building Waste Water Emuent Data.

Sheet 4 of 4

\author{
BOD $=$ Biological Oxygen Demand \\ PAH $=$ Polycyclic Aromatic Hydrocarbons \\ SVOC $=$ Semi-Volatile Organic Compound \\ TDS $=$ Total Dissolved Solids \\ TIC $=$ Tenatively Identified Compound \\ TKN = Total Kjeldahl Nitrogen \\ TOC $=$ Total Organic Carbon \\ TOX $=$ Total Organic Halide \\ TSS $=$ Total Suspended Solids \\ VOC $=$ Volatile Organic Compound
}

$\mathrm{mg} / \mathbf{L}=$ milligrams per liter

$\mathrm{pCi} / \mathrm{L}=$ picocuries per liter

$\mathrm{ug} / \mathrm{L}=$ micrograms per liter

a $\quad n=$ Number of sample results averaged.

mean conc $=$ mean concentration

S.D. = one standard deviation about the mean

b Three digit numbers with a decimal (i.e. 120.1, 300.0 etc.) are from EPA 1979.

Four digit procedure numbers (i.e. 6010, 9131 etc.) are from EPA 1992 . Four digit numbers with a letter following (i.e., 5210B) are from "Standard Methods for the Examination of Water and Wastewater", 18th Edition, (APHA, 1992). D.L. detection level as reported by the laboratory or procedures $(P)$ if no D.L. was reported with the data.

d Qualifiers which may appear in this table are:

(U) - Indicates the compound or analyte was analyzed for and not detected in the sample. The value reported is the sample quantitation limit (D.L.) corrected for sample dilution by the laboratory.

(J) - Indicates the compound or analyte was analyzed for and detected, but due to a QC deficiency identified during data validation, the associated quantitation limit is an estimate. This flag is also used when estimating concentrations of TICs or when the presence of a target compound is confirmed at a concentration of less than the D.L. but greater than the instrument detection limit.

(B) - This flag applies to results in which the analyte was detected in both the sample and the associated blank. For the metals, (B) also indicates the analyte concentration is less than the D.L. but greater than the instrument detection level.

Data qualifiers may appear in combinations. An alpha numeric combination (i.e., U2) indicates that two of the sample results used in the mean had a (U) qualifier. Two qualifiers separated by a comma (i.e., B,U) indicates that one of the samples in the mean has a (B) qualifier and one has a (U) qualifier. 


\section{DOE/RL-94-24, Rev. 0 06/94}

200-E Chemical Drain Field

This page intentionally left blank. 
DOE/RL-94-24, Rev. 0

06/94

200-E Chomical Drain Fiold

\section{APPENDIX F}

STORM WATER

App F-i 
DOE/RL-94-24, Rev. 0 06/94

200-E Chemical Drain Field

This page intentionally left blank.

App F-ii 
DOE/RL-94-24, Rev. 0

06/94

200-E Chemical Drin Field

CONTENIS

SECTION F, ITEM 1

DO YOU HAVE A WASHINTON STATE STORM WATER BASELINE

GENERAL PERMITT $\ldots \ldots \ldots \ldots \ldots \ldots \ldots \ldots \ldots \ldots \ldots \ldots \ldots \ldots$

SECTION F, ITEM 2

HAVE YOU EVER APPLIED FOR A WASHINGTON STATE STORM

WATER BASELINE GENERAL PERMITI . . . . . . . . . . . . . . . F-1

SECTION F, ITEM 4

DESCRIBE THE SIZE OF THE STORM WATER COLLECTION

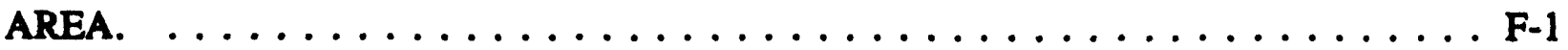

SECTION F, ITEM 5

DOES YOUR FACILITY'S STORM WATER DISCHARGE TO: $\ldots \ldots \ldots \ldots$. . . . F-2

SECTION F, ITEM 6

AREAS WITH INDUSTRIAL ACTTVITIES AT FACILITY: . . . . . . . . . F-3

SECTION F, ITEM 7A

MATERIAL HANDLING/MANAGEMENT PRACTICES. TYPES OF

MATERIALS HANDLED AND/OR STORED OUTDOORS: . . . . . . . . . . . F-5

SECTION F, ITEM 7B

MATERIAL HANDLING/MANAGEMENT PRACTICES. IDENTIFY

EXISTING MANAGEMENT PRACTICES EMPLOYED TO REDUCE

POLLUTANTS IN INDUSTRIAL STORM WATER DISCHARGES: . . . . . . . . F F-6

SECTION F, ITEM 8

ATTACH A MAP SHOWING STORM WATER DRAINAGE/COLLECTION

AREAS, DISPOSAL AREAS AND DISCHARGE POINTS. . . . . . . . . . . . F F-6 
DOE/RL-94-24, Rev. 0

06/94

200-E Chemical Drain Field

1
2
3
4
5
6

This page intentionally left blank. 
DOE/RL-94-24, Rev. 0

06/94

200-E Chemical Drin Field

\section{SECTION F}

Due to the overlap between Items 1 and 2, the items were combined and addressed in the following statement.

\section{SECTION F, ITEM 1}

DO YOU HAVR A WASBINGTON STATE STORM WATTR BASELTNE GENTERAL PERMTT?

\section{SECTION F, ITEM 2}

\section{HAVE YOU EVER APPLIED FOR A WASHINGTON STATE STORM WATER BASELINE GFNERAL PERMTT.}

Federal facilities are excluded from coverage under the Washington State Storm Water Baseline Permit, as are industrial facilities which have no point source discharge to surface water or a municipal storm sewer. However, a National Pollutant Discharge Elimination System (NPDES) General Permit was developed by EPA on September 9, 1992 for federal facilities located in Washington State, engaged in discharging storm water associated with industrial activities. To obtain site coverage under the NPDES General Permit, DOE-RL filed a Notice Of Intent application before the EPA on October 1, 1992. Subsequently, the Hanford Site has been issued an NPDES General Permit Number WA-R-00-A1\%F for sitewide coverage of storm water discharge. As required by the NPDES General Permit, the Hanford Site is implementing a storm water pollution prevention program according to the Hanford Site Stormwater Pollution Prevention Plan (WHC 1993b). Storm water discharges from the 200 East, 200 West and 400 Areas have no potential discharge to the Columbia or Yakima Rivers and thus were not included in the Hanford Site Stormwater Pollution Prevention Plan (WHC 1993b).

\section{SECTION F, ITEM 4}

\section{DESCRIBE THE SIZE OF THE STORM WATER COLLECTION AREA.}

The 272-E Building and 2703-E Building storm waters are not discharged from a point source to the 200-E Chemical Drain Field. Therefore, the storm water collection area is zero.

Facility boundaries have been drawn surrounding the 272-E Building and the 2703-E Building to answer the remaining questions in Section F. The facility boundaries are shown in Drawing H-13-000090. The notes and legend are depicted on Drawing H-13-000091. 
DOE/RL-94-24, Rev. 0

$06 / 94$

200-E Chomical Drain Field

1 SECTION F, ITEM 5

2 DOES YOUR FACT WUY'S STORM WATER DISCAARGE TO:

4

5 Item 5 is not applicable to the 272-E and 2703-E Buildings because the size of the 6 storm water collection area requested in Item 4 is zero.

7

8 
DOE/RL-94-24, Rev. 0

$06 / 94$

200-E Chemical Drain Fiald

1 SDCTION F, ITEM 6

AREAS WUTH INDUSTRIAL ACTUVWUES AT FACTWT: (CHECR ALL THAT

APPLD

272-E The 272-E facility boundary shown in Drawing H-13-000090 was used to answer Item 6.

10

11

12

13

X Manufacturing Building

$\square$ Material Handling

X Material Storage

$\square$ Hazardous Waste Treatment, Storage, or Disposal (Refers to RCRA, Subtitle C Facilities Only)

$\square$ Waste Treatment, Storage, or Disposal

$\square$ Application or Disposal of Waste Waters

$\square$ Storage and Maintenance of Material Handling Equipment

$\square$ Vehicle Maintenance

$\square$ Areas Where Significant Materials Remain

Х Access Roads and Rail Lines for Shipping and Receiving

$\square$ Other 
DOE/RL-94-24, Rev. 0

06/94

200-E Chemical Drain Fiald

2703-E The 2703-E Facility boundary shown in Drawing H-13-000090 was used to answer Item 6.

3

4

6

$\square$ Manufacturing Building

7

8

x Material Handling

9

10

X Material Storage

11

12

13

14

15

16

17

18

19

20

21

22

23

24

25

26

27

28

29

Hazardous Waste Treatment, Storage, or Disposal (Refers to RCRA, Subtitle C Facilities Only)

$\square$ Waste Treatment, Storage, or Disposal

$\square$ Application or Disposal of Waste Waters

7 9

$\square$ Vehicle Maintenance 1

$\square$ Areas Where Significant Materials Remain 23

X Access Roads and Rail Lines for Shipping and Receiving 6 7 
DOE/RL-94-24, Rev. 0

06/94

200-E Chemical Drin Field

1 SECTION F, ITEM 7A

2

3 MATIRRIAL HANDLUNGMANAGEMTANT PRACTUCES,

4

5 TYPES OF MATERIALS HANDLED AND/OR STORED OUTDOORS: (CHECK ALL

6 THAT APPLY

7

8
X Hazardous Wastes

X Scrap Metal

Acids or Alkalies

Petroleum or Petrochemical Products

Paints/Coatings

Plating Products

Woodtreating Products

X Other (List) Gas Bottles

Scrap metal is stored uncovered in the fenced storage yard behind the building.

Hazardous wastes are stored in a cabinet located outside and are handled only in transit to the cabinet. Gas bottles, both empty and full, are located under covered storage outside the building and are handled only during transfer from storage to the building.

2703-E The 2703-E facility boundary in Drawing H-13-000090 was used to answer Item 7a.

$\square$ Solvents

X Scrap Metal

Petroleum or Petrochemical Products

Plating Products

Pesticides
X Hazardous Wastes

Acids or Alkalies

Paints/Coatings

Woodtreating Products

X Other (List) Chemicals stored in in conex box. empty/used gas bottles 
Hazardous wastes are stored in the 90-day dangerous waste storage pad. The pad is enclosed on all sides, is covered, and is equipped with spill containment features. The chemical conex box also is enclosed and covered. These wastes and materials are handled only when transferred between the building and the storage area.

\section{SECTION F, ITEM $7 B$}

\section{MATERIAL HANDLNGGMANAG MMENT PRACTUCES.}

\section{IDENTIFY EXISTING MANAGEMIENT PRACTICES EMPLOYED TO REDUCE POLLUTANTS IN INDUSTRIAL STORM WATER DISCHARGES:}

Item $7 \mathrm{~b}$ is not applicable to the 272-E and 2703-E Buildings because the size of the storm water collection area requested in Item 4 is zero.

\section{SECTION F, ITEM 8}

\section{ATTACH A MAP SHOWNG STORM WATER DRANAGE/COLLECTION AREAS, DISPOSAL AREAS AND DISCHARGE POINTS.}

The storm water collection area requested in Item 4 is zero. Therefore, no map has been included showing storm water drainage/collection areas, etc. In lieu of a storm water boundary map, facility boundaries have been drawn around the 272-E and 2703-E Buildings. The facility boundaries are shown in Drawing H-13-000090.

Although there is no storm water collection area for the 272-E Building, storm water is managed using rain gutters and downspouts. The 272-E Building roof collects storm water and discharges it directly to the ground through rain gutters and down spouts. Rain gutters run along the northwest, southwest, and southeast roof edges, covering approximately $1 / 4$ of the building. Downspouts are located on the southeast and southwest corners of the building, allowing the storm water to discharge directly to the ground. Locations of downspouts are shown on Drawing H-13-000090. 

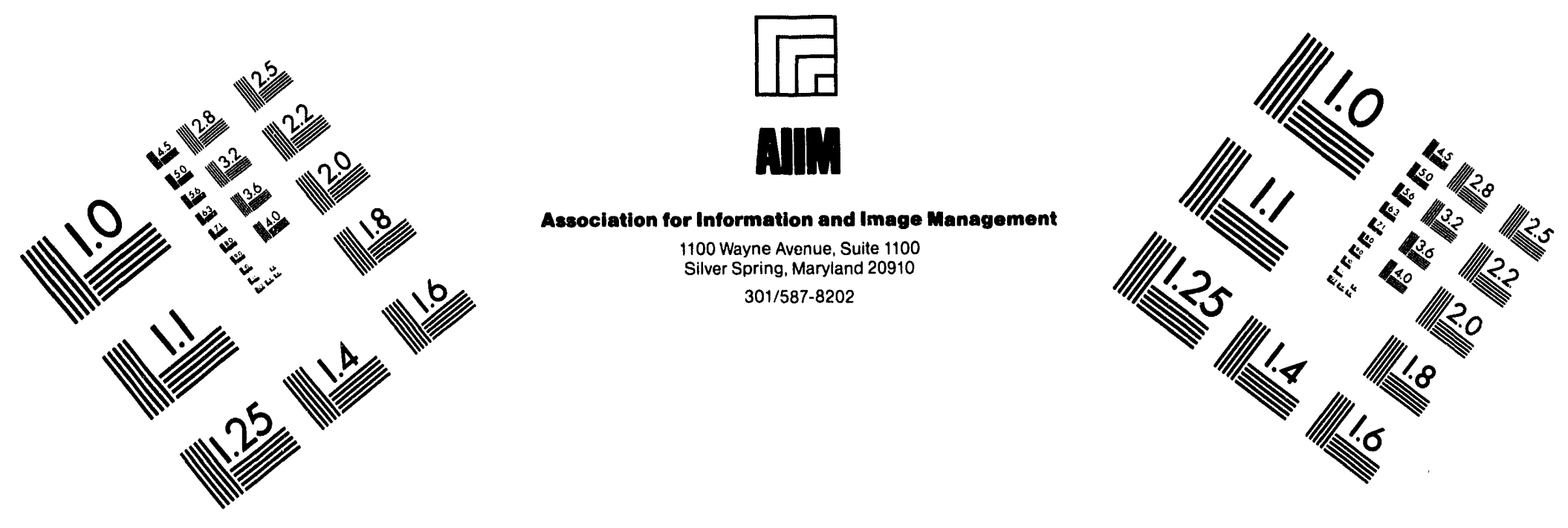

\section{Centimeter}

1 15 Inches
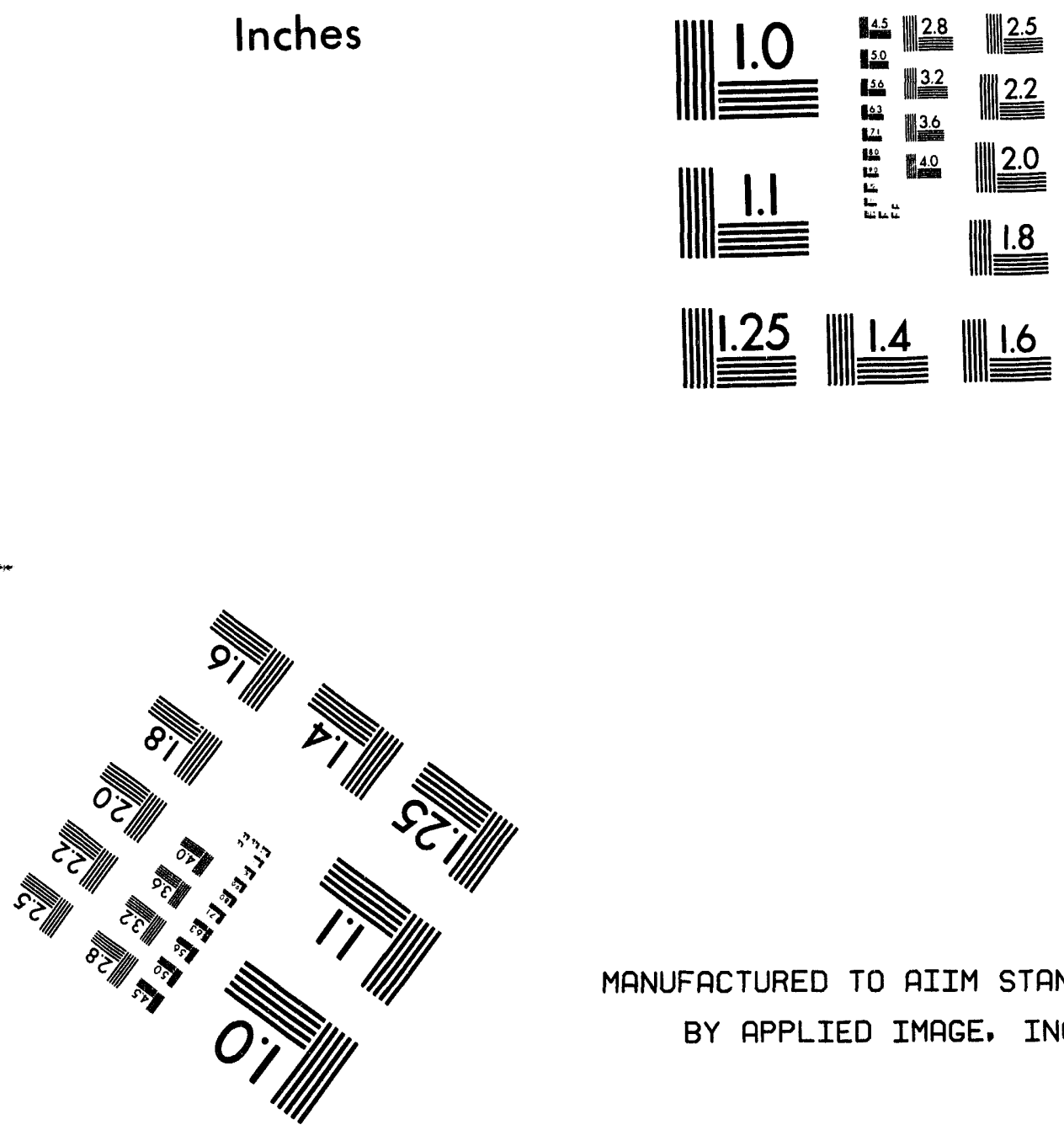

MANUFACTURED TO AIIM STANDARDS

BY APPLIED IMAGE, INC.

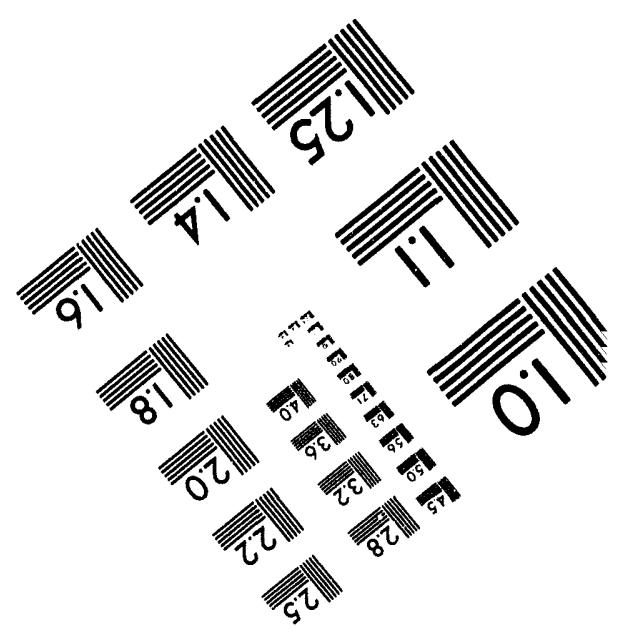



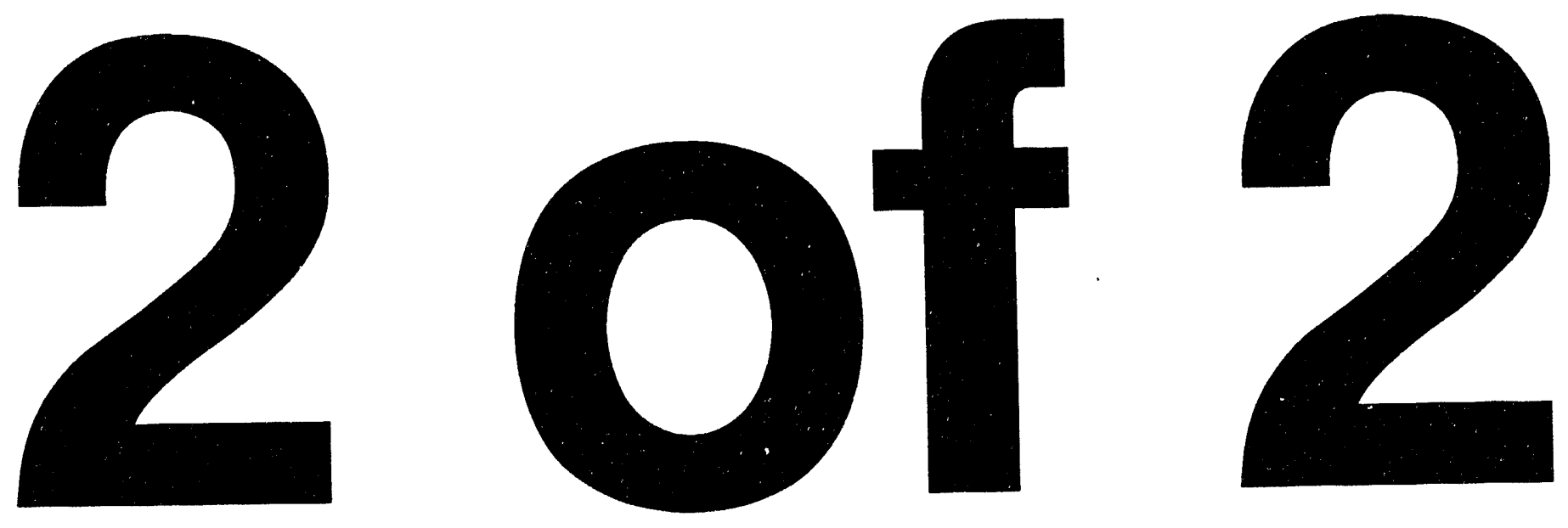
N. 135,950

N. 135,750
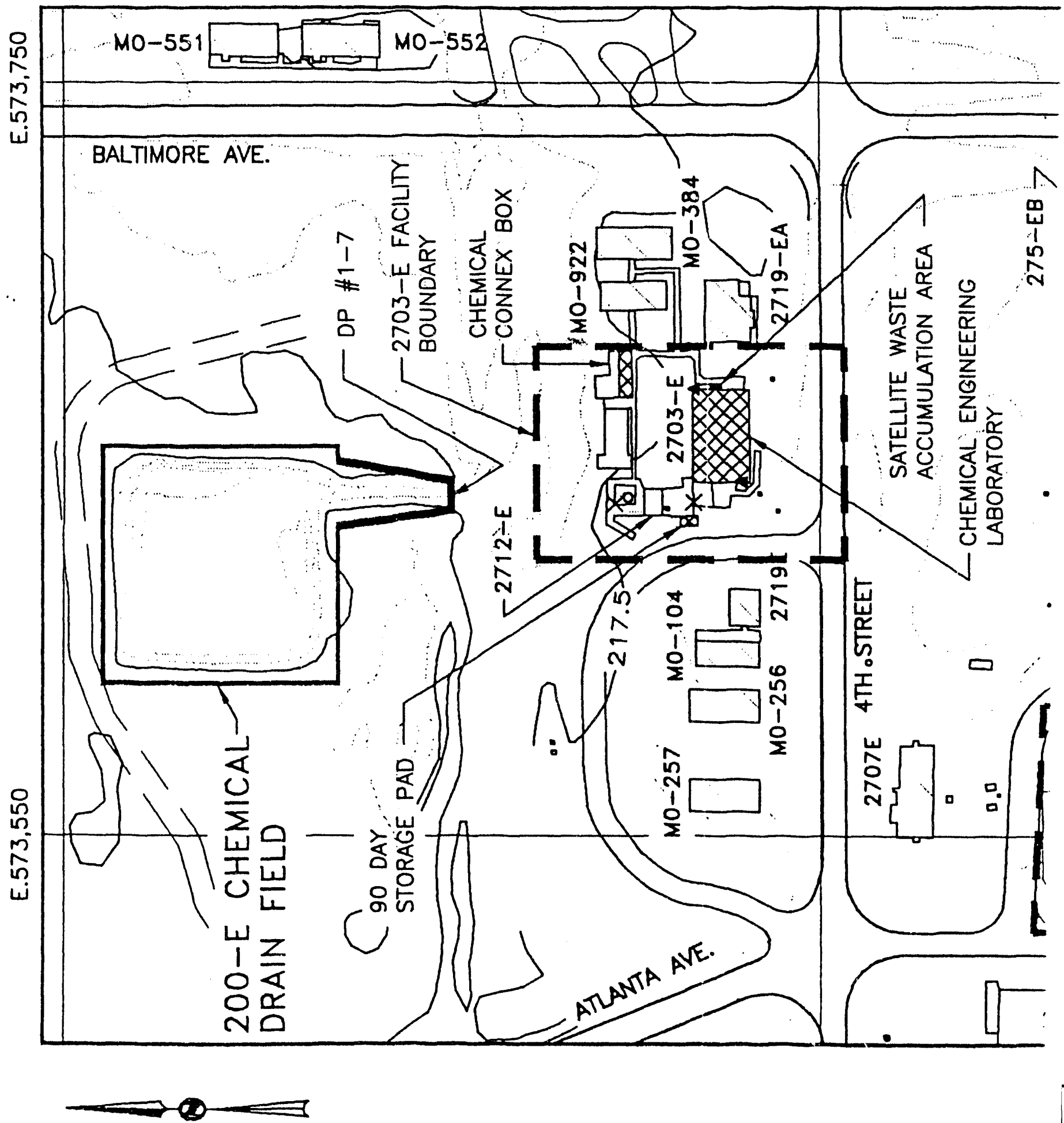

\begin{tabular}{l|l} 
H-13-000222 & 200E AREA TOPOGRAPHIC MAP
\end{tabular}

\begin{tabular}{|c|c|c|}
\hline$\underset{\text { NOV }}{R E V}$ & DESCRIPTON & $\begin{array}{l}\text { REV } \\
\text { oir } \\
\text { oire }\end{array}$ \\
\hline
\end{tabular}
REPRENCE 
N. 135,550
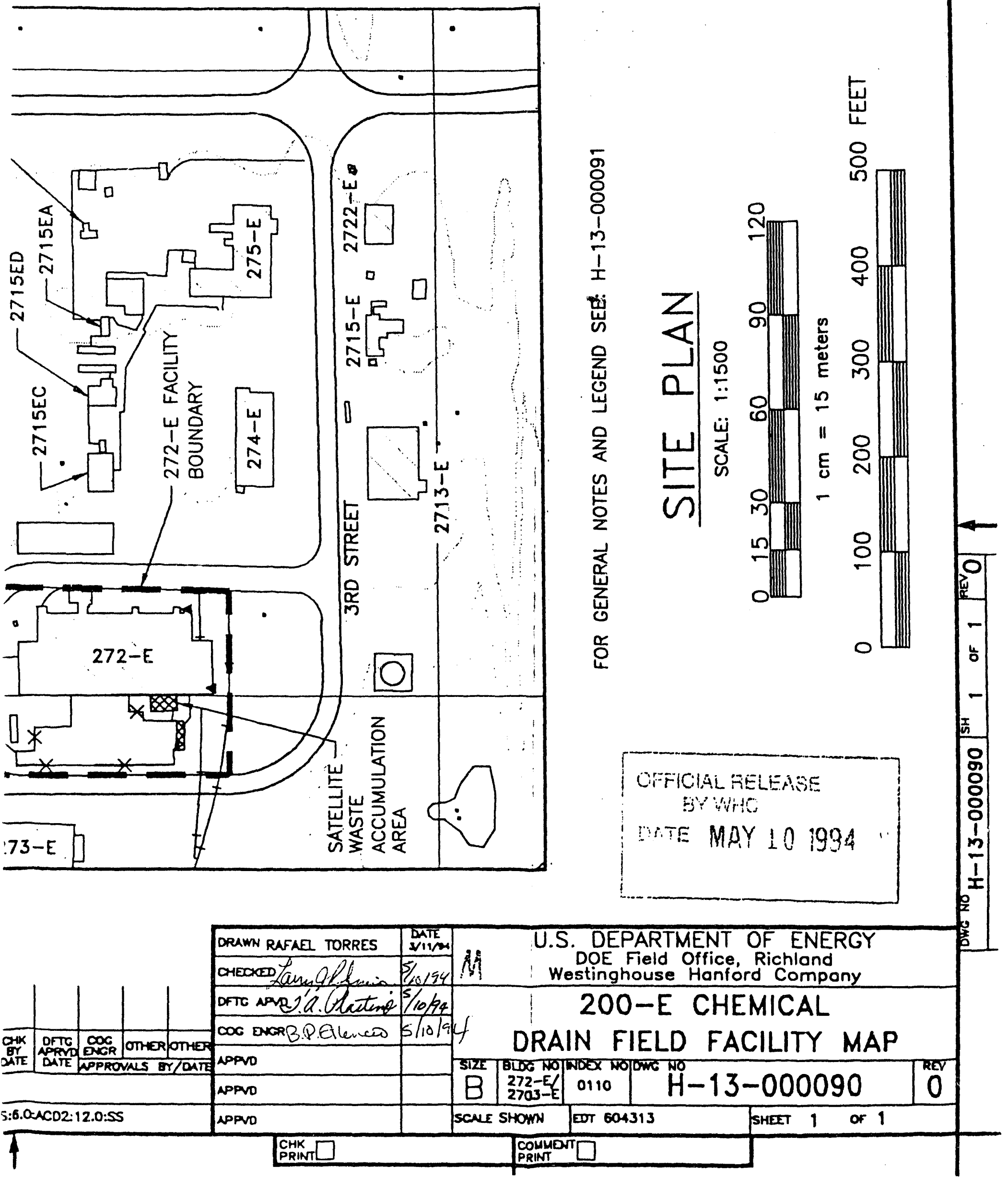

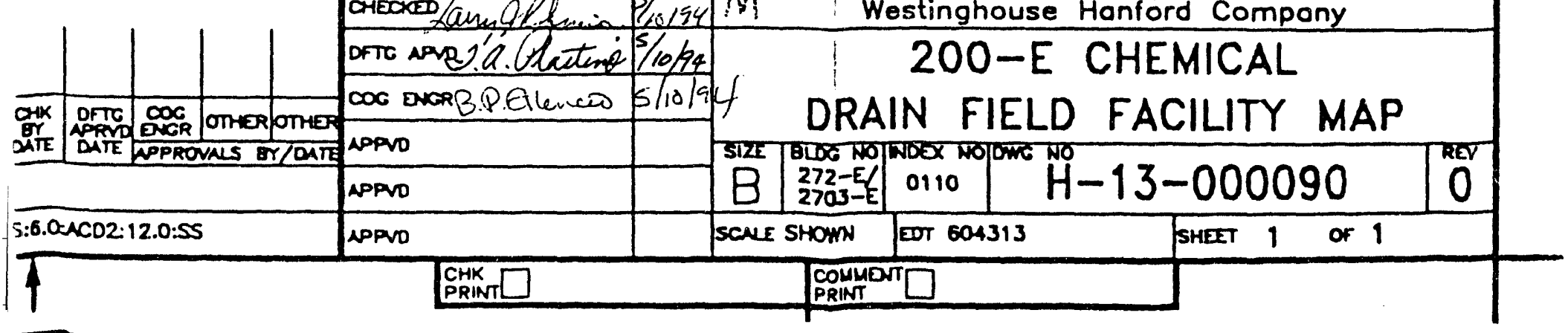


WIND ROSE FOR: 2O0E AREA

$\pi$ CALM WINDS $=.7$

STATION NO.6
PERIOD COVERED

$1 / 1 / 93-12 / 31 / 93$

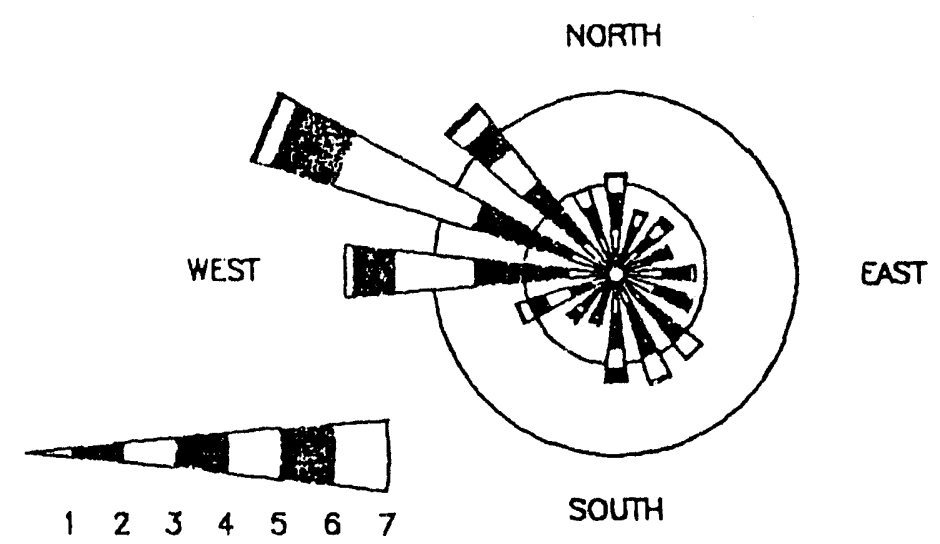

PADDLES INOICATE DIRECTION WINO IS COMING FROM.

RADIAL GRIDS REPRESENT. 5.0\% AND 10.0\% OCCURRENCE.

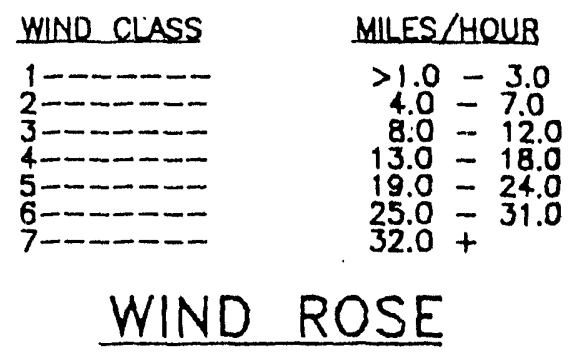

\section{LEGEND}

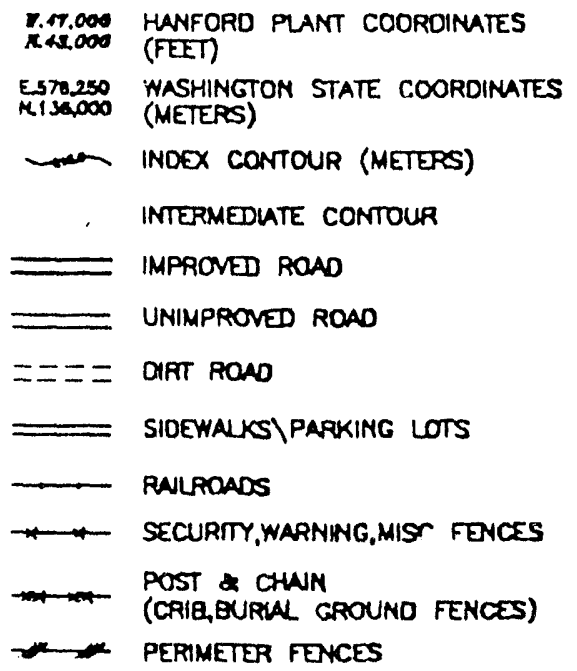

QULLINGS/STRUCTURES

242-A BUILDING NUMBER

Ex-1 Well

() O TANKS

216-A-42 CAR

218-E-10 BURWL GROUND

CHOMICAL HWNOUNG ANO STORAGE FACIUTES

DP OISCHARCE POINT

A DONmsPouts

\begin{tabular}{|c|c|c|c|c|c|}
\hline $\mathrm{H}-13-000089$ & 200-E POWERHOUSE ASH PIT FACIUTY MAP & & & & \\
\hline $\mathrm{H}-13-000090$ & 200-E CHEMICAL DRAIN FIELD FACIUTY MAP & \multirow{2}{*}{ MFG $\begin{array}{l}\text { REV } \\
\text { NO }\end{array}$} & \multirow{2}{*}{ DESCRIPTION } & \multirow{2}{*}{ 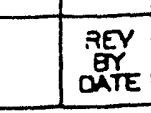 } & \multirow{2}{*}{$\begin{array}{c}\text { CHr } \\
\text { gr } \\
\text { OArt }\end{array}$} \\
\hline REF NUMBER & TILE & & & & \\
\hline \multicolumn{2}{|r|}{ REFERENCE } & agr & \multicolumn{3}{|c|}{ REVSIONS } \\
\hline NEXT USED ON & $H-13-000200$ & CAOFILE & & CADCODE 0 & os: 6 \\
\hline
\end{tabular}




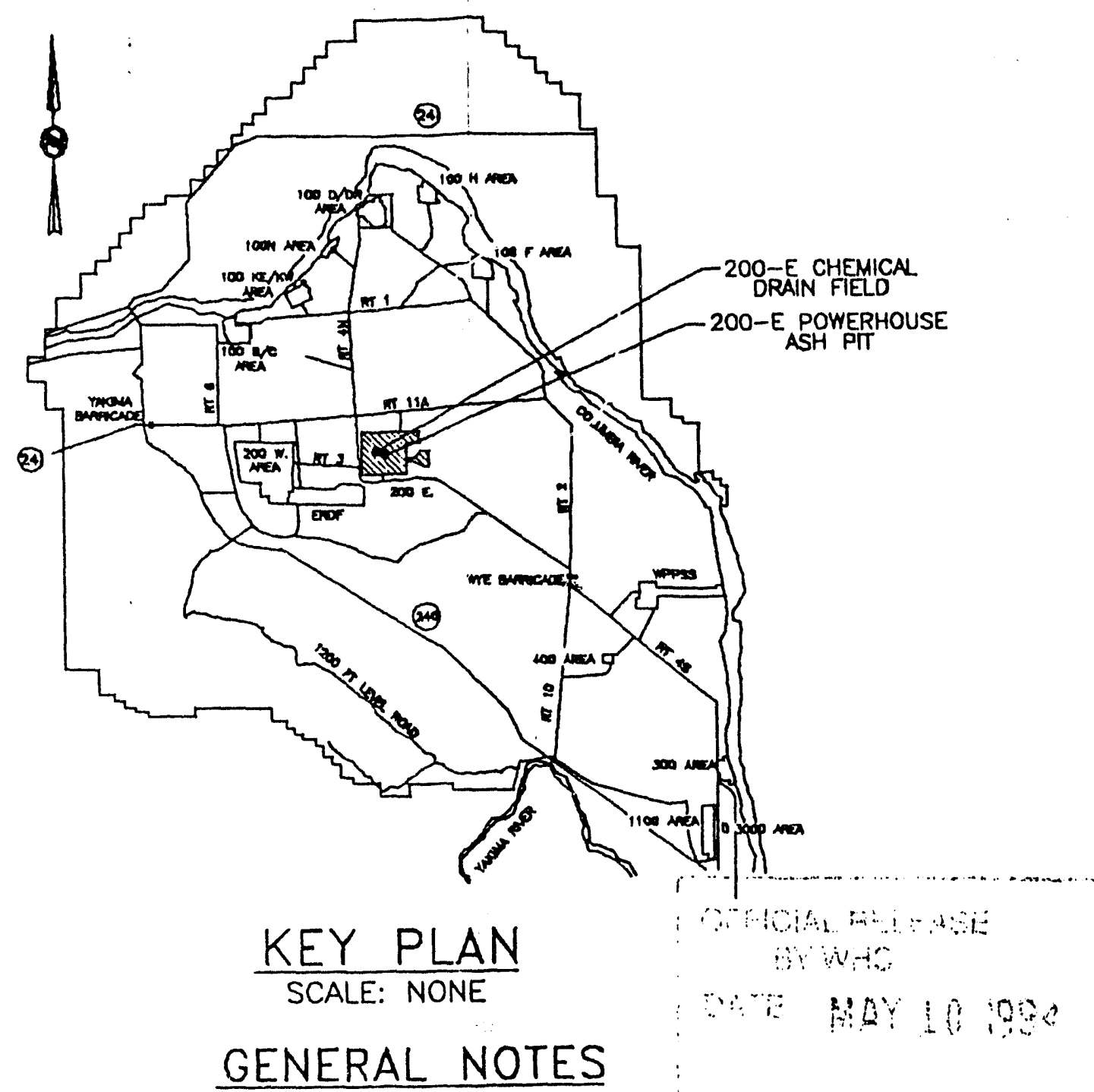

1. THESE GENERAL NOTES AND LEGEND ARE FOR H-13-000089 AND H-13-000090.

2. THIS MAP IS BASED ON AERWL PHOTOGRAPMT FLOWN ON 6-24-89. THE ORIGINAL TOPOGPUPHIC MAP WAS PREPARED GY MERRICK \& COMPANY ANO CERTIFIED TO MEET NATIONAL MAP ACCURACY STANDARDS.

OFFCLAL COPIES OF THE MERRICK MUPS THAT SHOW THE CERTIFICATE ARE LOCATED IN THE WESTINGHOUSE

ENGINEERING FILS AS DRAWING NUMBERS $\mathrm{H}-2-79476$ SHEET I AND $\mathrm{H}-2-79477$ SHEET I THRU 37.

NANES OF ADOTIONL FEATURES AND THE TILE GLOCK WERE ADOED EY WESTINGHOUSE HWFORD COMPANY.

3. WASHINGTON STATE PLANE COORDINATE SYSTEM: THE OFTICIAL COOFDINATE SYSTEM AS DEFINED GY THE REVISED CODE OF WASHINGTON (RCM. THE HANFORD STIE LES WITHIN THE WASHINGTON COORDINMTE STSTEM. SOUTH ZONE. THIS GRIO COVERS THE ENTRE STIE AND USES X (EASTINGS) AND Y (NORTHINGS) COORDINATES

HORIZONTAL OATUM: NUD-83 LAMBERT PROJECTION. WASHINGTON STATE PLANE COORDINATES ARE SHOWN IN METERS. CONTOUR INTERNAL: 0.5 METEPS.

4. HANFORO PLANT GRID: A LOCAL GRID STSTEM WITH ITS INTML POINT NORTHEAST OF THE 400 AREA IT COVERS 200 EAST AND 200 WEST AREA AS WEL AS GENERAL STE WORK SUCH AS WELIS NDO BURAL GROUNDS. HANFORO CDORDINATES ARE SHOWN IN FEET

5. THIS MUP IS TO BE USED FOR REFERENCE PURPOSES ONLY. DO NOT USE THIS MAP FOR CONSTRUCTON PURPOSES.

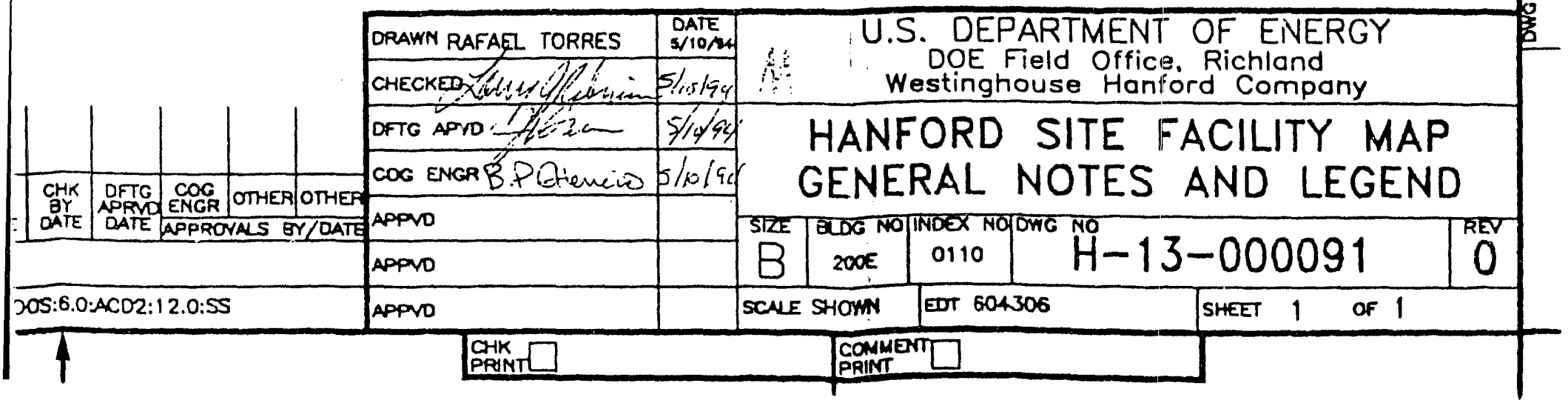




\section{DOE/RL-94-24, Rev. 0 \\ 06/94 \\ 200-E Chemical Drain Field}

\section{APPENDIX G}

\section{OTHIDR INFORMATON}


DOE/RL-94-24, Rev. 0 06/94

200-E Chemical Drain Field

This page intentionally left blank. 
DOE/RL-94-24, Rev. 0 $06 / 94$

200-E Chemical Drain Field

\section{CONTENTS}

SECTION G, ITEM 1

DESCRIBE LIQUID WASTES OR SLUDGES BEING GENERATED THAT ARE NOT DISPOSED OF IN THE WASTE STREAM(S) AND HOW THEY ARE DISPOSED OF. FOR EACH TYPE OF WASTE, PROVIDE TYPE OF WASTE, NAME, ADDRESS, AND PHONE

NUMBER OF HAULER. $\ldots \ldots \ldots \ldots \ldots \ldots \ldots \ldots \ldots \ldots$ G-1

SECTION G, ITEM 2

DESCRIBE STORAGE AREAS FOR RAW MATERIALS, PRODUCTS,

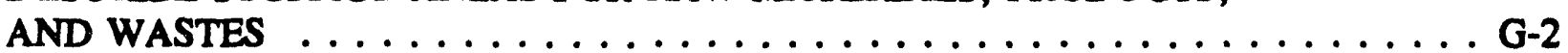


DOE/RL-94-24, Rev. 0 06/94

200-E Chemical Drain Field

1

2

3

4

5

6

This page intentionally left blank. 
DOE/RL-94-24, Rev. 0

06/94

200-E Chomical Drain Fiold

\section{SECTION G, ITEM 1}

\section{DESCRIBE LOUID WASTES OR SLUDGES BEING GENERATEDD THAT ARE NOT DISPOSED OF IN THIE WASTE STREAM(S) AND BOW TUHEY ARE DISPOSED OF. EOR FACH TOPE OF WASTE, PROVIDE TUPE OF WASTE, NAMT, ADDRESS, AND PHONENUMBER OF HAUMFR.}

Chemical waste could be generated during the activities in the 2703-E Building. Waste is packaged and a written request for disposal is submitted to WHC Solid Waste Management. If waste is liquid and nonregulated, it may be disposed of in the process sewer. If waste is considered solid and/or regulated, it must be disposed of by a means other than discharging to the process sewer. WHC Solid Waste Management offers options for disposal.

Some dirt and grit are left over when the north and south sumps inside the 2703-E Building are discharged. The dirt and grit enter the sump when the floors are washed. The sumps are vacuumed approximately once a week (when the sumps are drained) to remove the dirt. The vacuumed material is a nonhazardous, nonregulated solid waste and is disposed of accordingly, with other nonhazardous solid waste streams generated at the 2703-E Building.

Inorganic waste from laboratory activities is collected in satellite waste accumulation areas inside the building. When the satellite containers are full, they are moved to the $90-$ day dangerous waste storage pad located outside on the west side of the building. Organic waste from laboratory activities is collected in a separate satellite container inside the building or a flammable container outside the building. These containers are transferred to the 90-day dangerous waste storage pad when full. Waste is transported from the 90-day dangerous waste storage pad to the 616 Nonradioactive Dangerous Waste Storage Facility by:

Solid Waste Disposal

Westinghouse Hanford Company

P.O. Box 1970

MSIN N3-11

Richland, WA 99352.

(509) 376-4646

Domestic waste water from the 272-E and 2703-E Buildings is discharged to the 2607E1 septic tank. This septic tank is pumped periodically as a preventative maintenance measure and waste is transported to the 100-N Sewage Lagoon. WHC Sanitary Systems Maintenance hauls the domestic waste water from the septic tanks to the 100-N Lagoon. WHC also contracts to have Roto Rooter haul the sewage. The addresses are as follows: 
Sanitary Systems Maintenance Westinghouse Hanford Company P.O. Box 1970 MSIN S4-61 Richland, WA 99352 (509) 373-5786
Roto-Rooter Sewer Service Co. Route 4 - Box 4000-D

Kennewick, WA 99336

(509) 783-7311

Satellite waste accumulation areas are located outside of the 272-E Building. Waste kept here consists of paints and solvents, paint rags, and dye-penetrant rags. When satellite containers are full, they are transferred to the 90-day dangerous waste storage pad at the 2715-EA Building. From here the waste is hauled to the 616 Nonradioactive Dangerous Waste Storage Facility by Solid Waste Disposal.

\section{SECTION G, ITEM 2}

\section{DESCRIBE STORAGE AREAS FOR RAW MATERIALS, PRODUCTS, AND WASTES}

\section{Storage Yard at the 272-E Building (Raw Materials)}

A large fenced area on the west side of the 272-E Building is used as a material storage area. Piping and other metal stock are stored on racks.

\section{Satellite Waste Accumulation Areas at the 272-E Building}

Cabinets serv: as satellite waste accumulation areas at the 272-E Building. The cabinets are located outside on the west side of the building in a small fenced area. The cabinets are locked and protected from storm water. The fenced area is also locked. The waste stored here includes paints, solvents, paint rags, and dye-penetrant rags.

\section{Organic Satellite Waste Accumulation Area at the 2703-E Building}

Liquid organic waste from laboratory activities is collected in satellite waste accumulation areas inside the building. Solid organic waste (e.g., rags containing organic materials) is collected in secure satellite enclosures outside of the building. The satellite waste accumulation areas have secondary containment. 
1 Inorganic Satelitte Hazardous Waste Accumulation Area at the 2703-E Building

2

3

4

5

6

7

8

9

10

11

Inorganic waste from laboratory activities is collected in satellite accumulation areas located inside the building. The satellite accumulation areas have secondary containment.

90-Day Dangerous Waste Storage Pad at 2703-E

The 90-day dangerous waste storage pad is a pre-engineered building with three separate compartments. Each compartment is heated to prevent the waste from freezing. Each compartment's electrical system is explosion proof and has a sump for secondary containment of spills. Filled satellite containers from the laboratory are stored on the 90-day dangerous waste storage pad for up to 90 days before to transport to the 616 Nonradioactive Dangerous Waste Storage Facility. 
a $\operatorname{awn}$.

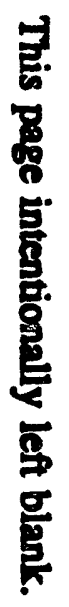

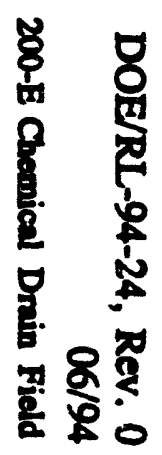


DOE/RL-94-24, Rev. 0

06/94

200-E Chemical Drain Field

\section{APPENDEX $\mathrm{B}$}

\section{STTE ASSESSMIENT}

App H-i 
DOE/RI-94-24, Rev. 0

06/94

200-E Chemical Drain Field

This page intentionally left blank. 
DOE/RL-94-24, Rev. 0

$06 / 94$

200-E Chemical Drain Fiold

CONTENTS

SECTION H, ITEM 1

GIVE THE LEGAL DESCRIPTION OF THE LAND TREATMENT

SITE(S). GIVE THE ACREAGE OF EACH LAND TREATMENT

SITE(S). ATTACH A COPY OF THE CONTRACT(S) AUTHORIZING

USE OF LAND FOR TREATMENT. $\ldots \ldots \ldots \ldots \ldots \ldots \ldots \ldots \ldots \ldots$ H-1

SECTION H, ITEM 2

LIST ALL ENVIRONMENTAL CONTROL PERMTTS OR APPROVALS

NEEDED FOR THIS PROJECT; FOR EXAMPLE, SEPTIC TANK

PERMITS, SLUDGE APPLICATION PERMTTS, OR AIR EMISSIONS

PERMTTS. $\ldots \ldots \ldots \ldots \ldots \ldots \ldots \ldots \ldots \ldots \ldots \ldots \ldots \ldots$ H-

SECTION H, ITEM 3

ATTACH A UNITED STATES GEOLOGICAL SURVEY (USGS)

TOPOGRAPHIC MAP. SHOW THE FOLLOWING ON THIS MAP: $\ldots \ldots \ldots \ldots$ H-1

SECTION H, ITEM 4

ATTACH WELL LOGS AND WELL I.D.\# WHEN AVAILABLE FOR

ALL WELLS WITHIN 500 FEET AND ANY AVAILABLE WATER

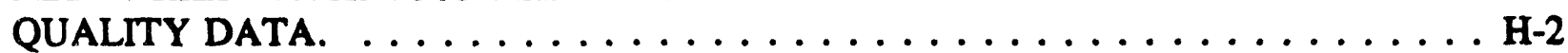

SECTION H, ITEM 5

DESCRIBE SOILS ON THE SITE USING INFORMATION FROM

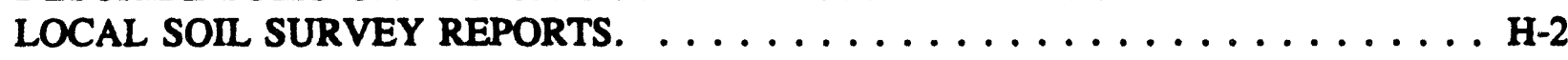

SECTION H, ITEM 6

DESCRIBE THE REGIONAL GEOLOGY AND HYDROGEOLOGY

WITHIN ONE MILE OF THE SITE. $\ldots \ldots \ldots \ldots \ldots \ldots \ldots \ldots \ldots$ H-3

SECTION H, ITEM 7

LIST THE NAMES AND ADDRESSES OF CONTRACTORS OR CONSULTANTS WHO PROVIDED INFORMATION AND CITE

SOURCES OF INFORMATION BY TITLE AND AUTHOR. . . . . . . H H-12 
DOE/RC-94-24, Rev. 0

$06 / 94$

200-E Chemical Drain Field

\section{ETURES}

H-1 Hanford Soils Map . . . . . . . . . . . . . . . . . H-13

H-2 Soils Map for the 200-E Chemical Drain Field . . . . . . . . . . . H-14

H-3 Hanford Goologic Map . . . . . . . . . . . . . . . . . H-15

H-4 Legend for Hanford Geologic map . . . . . . . . . . . . . H-16

H-5 Regional Stratigraphic Column $\ldots \ldots \ldots \ldots \ldots \ldots \ldots \ldots \ldots \ldots$ H-17

H-6 Geology Map for the 200-E Chemical Drain Field . . . . . . . . . . . H-18

H-7 Line of Cross-Section for the 200-E Area . . . . . . . . . . . . . . . H-19

H-8 Cross-Section for the 200-E Area . . . . . . . . . . . . . . H-20

H-9 Hanford Water Table Map. . . . . . . . . . . . . . . H-21 


\section{SECTION H, ITEM 1}

GTVE THE IFGAL DESCRIPTION OF THE WAND TREATMTNAT STTE(S), GIVE THE ACRSAGE OF FACH LAND TREATMTENT STTE(S). ATTACH A COPY OF THE CONTRACT(S) AUTHOORVING USE OF LAND FOR TREATMIENT.

Legal Description:

NW 1/4, SE 1/4, Section 3, Township 12N, Range 26E, Benton County, WA.

The land treatment site has the following acreage:

200-E Chemical Drain Field (Total Area): 0.55 acre

A specific contract authorizing use of the 200-E Chemical Drain Field for a land treatment site does not exist, but the Hanford Site was created by the U.S. Government to serve as a research and production facility for federal government nuclear projects. The Hanford Site has been in use since the early 1940's and all disposal facilities, such as the 200-E Chemical Drain Field, have been authcrized by the U.S. Govermment.

\section{SECTION H, ITEM 2}

\section{LIST ALL ENVIRONMENTAL CONTROL PERMITS OR APPROVALS NEEDED}

FOR THIS PROIECT: FOR EXAMPLE, SEPTIC TANK PERMITS, SLUDGE

APPLICATION PERMITS, OR AIR EMISSIONS PERMITS,

There are no permits specifically for this project. The following permits are general permits for the Hanford Site:

- Hanford Site Radioactive Air Emissions Permit: Number FF-01

- Hanford Site Dangerous Waste Permit: Number WA7890008967

- NPDES General Permit: Number WA-R-00-A17F.

\section{SECTION H, ITEM 3}

\section{ATTACH A UNITED STATES GEOLOGICAL SURVEY (USGS) TOPOGRAPHIC MAP. SHOW THE FOLLOWING ON THIS MAP:}

a. Location and name of internal and adjacent streets

b. Surface water drainage systems within $1 / 4$ mile of the site 
DOE/RL-94-24, Rev. 0

06/94

200-E Chemical Drain Field

c. All wells within 1 mile of the site

d. Chemical and product handling and storage facilities

e. Infituration sources, such as drainfields prod lagoons within 1/4 mile of the sife

f. Waste water and cooling water discharge points with waste stream ID numbers (See Section C.1)

8. Other setivities and land uses within 1/4 mile of the site

Drawing H-13-000086 addresses the above items as applicable. Although this drawing is not a USGS topographic map, it was derived from the Hanford Site topographic map database. The Hanford Site map database provides more detail and allows the items to be addressed at a more appropriate scale than a USGS map. The waste water discharge point shown for the waste stream on Drawing H-13-000086 includes all component substreams prior to discharge. The chemical and product handling and storage areas are difficult to see on a map of this scale and are shown on Drawing H-13-000090 in Appendix F.

\section{SECTION H, ITEM 4}

\section{ATTACH WELC LOGS AND WELL I.D." WHEN AVAILABLE FOR ALL WELLS WITHIN 500 FEET AND ANY AVAILABLE WATER OUALTTY DATA.}

Drawing H-13-000086 shows ail of the wells within a one-mile radius of the 200-E Chemical Drain Field. All well numbers are preceeded with a 299. There are no wells within 500 feet of the 200-E Chemical Drain Field.

\section{SECTION H, ITEM 5}

\section{DESCRIBE SOINS ON THE STTE USING INFORMATION FROM LOCAL SOIL SURVEY REPORTS.}

The most recent study of the soil on the Hanford Site was done by Hajek (1966). This study presents a soil map and a descriptive report of soils in the Benton County portion of the Hanford Site. On the basis of morphologic and genetic characteristics, 13 soil types were identified. An approximate land use capability classification is provided for these soils on the basis of soil limitations for, and damage risks associated with, agricultural use. Approximate engineering classifications for these soils, using the Unified Soil Classification System, are also provided in Hajek (1966). The soil types mapped on the Hanford Site are shown on Figure H-1. There is no soil data for the north slope of the Hanford Site. The soils in the vicinity of the 200 East Area consist of three soil types: the Burbank loamy sand, the Quincy sand (Rupert sand), and the Ephrata sandy loam. The following sections describe the soils types in the 200 East Area. A map depicting the soils within one mile of the 200-E Chemical Drain Field is provided as Figure H-2. 
The Burbank loamy sand is a dark grayish brown, coarse-textured, excessively drained soil underlain by gravel. The surface soil is usually about 16 inches thick, but can be as much as 30 inches. The gravel content of the subsoil may range from 20 to 80 percent (by volume). The surface of the Burbank loamy sand is Group SM (silty sand) and the subsoil is Group GM (silty gravel) to GP (poorly-graded gravel). Group GM (silty gravel) are coarsegrained soils composed predominantly of gravels with more than 12 percent fines. Group GP (poorly-graded gravel) contains coarse-grained soils that are predominantly well-sorted gravels with less than 5 percert fines.

The Quincy sand (Rupert sand) represents one of the most extensive soils at the Hanford Site. The soil is a brown to grayish brown, moderately-deep, coarse sand. Quincy soils developed under grass and sagebrush in coarse alluvial deposits mantled by wind-blown sand. Relief characteristically consists of hummocky terraces and dune-like ridges. The surface and subsoil of the Quincy sand (Rupert sand) were assigned to Group SM (silty sand), which consists of coarse-grained soils composed predominantly of sands with more than 12 percent fines.

The Ephrata sandy loam, occurring to an average depth of 12 inches, is a dark grayish brown, medium-textured soil underlain by deep gravely material. The topography is generally level. The surface of the Ephrata sandy loam belongs to Group SM (silty sand) to ML (silt), and the subsurface belongs to Group ML (silt). Group ML (silt) is fine-grained soils composed of silts and clays with little or no plasticity.

\section{SECTION H, ITEM 6}

\section{DESCRIBE THE REGIONAL GEOLOGY AND HYDROGEOLOGY WITHIN ONE MUE OF THESITE,}

\section{REGIONAL GEOLOGY}

A summary of the regional geologic characteristics of the Pasco Basin and the Hanford depicting the geology of the Hanford Site. Figure $\mathrm{H}-4$ is a legend explaining Figure H-3. 
DOE/RL-94-24, Rev. 0

06/94

200-E Chemical Drain Field

\section{REGIONAL STRATIGRAPHY}

The Hanford Site lies within the Pasco Basin, a regional structural and topographic, sediment-filled depression. The sediments of the Pasco Basin are underlain by Miocene-age basalt of the Columbia River Basalt Group, a thick sequence of flood basalts that covers a large area in castem Washington, western Idaho and northeastem Oregon. The sediments overlying the basalts, from oldest to youngest, include: the Miocene-Pliocene Ringold Formation, local alluvial deposits of possible late Pliocene or early Pleistocene age, local "Palouse" soil of mostly eolian origin, glaciofluvial deposits of the Pleistocene Hanford formation, and surficial Holocene colian and fluvial sediments. The generalized stratigraphy of the Hanford Site is described in the following paragraphs from the oldest to youngest formation. The regional stratigraphy is depicted on Figure H-5.

\section{Columbia River Basalt Group and the Ellensburg Formation}

The Columbia River Basalt Group consists of an assemblage of tholeiitic, continental flood basalts of Miocene Age with an accumulated thickness in excess of 10,000 feet within the Pasco Basin. These flows cover an area of more than 63,000 square miles in Washington, Oregon, and Idaho and have an estimated volume of about 40,800 cubic miles. The majority of the flows were erupted 14.5 to 17 million years ago (WHC 1991b).

The Columbia River Basalt Group is formally divided into five formations (from oldest to youngest): Imnaha Basalt, Picture Gorge Basalt, Grande Ronde Basalt, Wanapum Basalt, and Saddle Mountains Basalt. Of these, all are present within the Pasco Basin except for the Picture Gorge Basalt. The Saddle Mountains Basalt, divided into the Ice Harbor, Elephant Mountain, Pomona, Esquatzel, Asotin, Wilbur Creek, and Umatilla Members, forms the uppermost basalt unit throughout most of the Pasco Basin. The Elephant Mountain Member is the uppermost unit beneath most of the Hanford Site except near the 300 Area where the Ice Harbor Member is found and north of the 200 Areas where the Saddle Mountains Basalt has been eroded down to the Umatilla Member in the Gable Gap area (WHC 1991b). The Elephant Mountain Member has also been locally eroded in the vicinity of the northeast corner of the 200 East Area (WHC 1991b). On anticlinal ridgts bounding the Pasco Basin, erosion has removed the Saddle Mountains Basalt, exposing the Wanapum and Grande Ronde basalts (WHC 1991b).

The Ellensburg Formation consists of all sedimentary units that occur between the basalt flows of the Columbia River Basalt Group in the central Columbia Basin (Reidel and Fecht 1981). The Ellensburg Formation generally consists of two main lithologies: volcaniclastics and siliciclastics. The volcaniclastics consist mainly of primary pyroclastic air fall deposits and reworked epiclastics derived from volcanic terrains west of the Columbia Plateau. Siliciclastic strata consist of clastic, plutonic, and metamorphic detritus derived from the Rocky Mountain terrains located to the east. 
At the Hanford Site, the three uppermost units of the Ellensburg Formation are the Levy interbed, the Rattlesnake Ridge interbed, and the Selah interbed. The Levy interbed is confined to the vicinity of the 300 Area. The Rattleanake Ridge and Selah interbeds are found beneath most of the Hanford Site (WHC 1992a).

\section{Suprabasalt Sediments}

The suprabasalt sedimentary sequence at the Hanford Site is up to approximately 750 feet thick in the west-central Cold Creek syncline, while it pinches out against the anticlinal ridges that bound or are present within the Pasco Basin (WHC 1991a). The suprabasalt sediments are dominated by laterally extensive deposits of the late Miocene to Pliucene-age Ringold Formation and the Pleistocene-age Hanford formation. Locally occurring strata separating the Ringold and Hanford formations are assigned to the informally defined PlioPleistocene unit, early "Palouse" soil, and pre-Missoula gravels, which comprise the remainder of the sequence (DOE-RL 1993b).

Ringold Formation. Overlying the Columbia River Basalt Group is the late Miocene to Pliocene-age Ringold Formation (Fecht et al. 1987, DOE 1988). The Ringold Formation accumulated to a thickness of up to 1,200 feet in the Pasco Basin (Tallman et al. 1979). On the Hanford Site, the Ringold Formation is up to 600 feet thick in the deepest part of the Cold Creek syncline south of the $\mathbf{2 0 0}$ West Area and $\mathbf{5 6 0}$ feet thick in the western Wahluke syncline near the 100-B Area (WHC 1991b). The Ringold Formation pinches out against the anticlinal flanks that bound or are present within the Pasco Basin, and is largely absent in the northern and northeastern parts of the 200 East Area and adjacent areas to the north (WHC 1991b, WHC 1992a). The recent studies of the Ringold Formation (WHC 1991d) indicate it is best described on the basis of sediment facies associations and their distribution. The facies associations have been divided into fluvial gravel, fluvial sand, overbank deposits, lacustrine deposits, and alluvial fans. The lower Ringold contains five separate stratigraphic intervals dominated by fluvial gravels, which have been designated units A, B, C, D, and E, from oldest to youngest. These gravel units are separated by basin-wide overbank and lacustrine deposits (WHC 1992a). A more detailed discussion of the Ringold Formation stratigraphy can be found in WHC (1991d).

Post-Ringold Pre-Hanford Sediments. Thin alluvial deposits situated stratigraphically between the Ringold Formation and Hanford formation are found within the Pasco Basin. The three informally defined units include: the Plio-Pleistocene unit, the early "Palouse" soil, and the Pre-Missoula gravels. The Plio-Pleistocene unit and early "Palouse" soil are not found in or near the 200 East Area. They are found to the west of the site area near the eastern boundary of the $\mathbf{2 0 0}$ West Area. The pre-Missoula gravels are not found in the site area. The Plio-Pleistocene unit and early "Palouse" soil are described in detail in PNL (1989) and WHC (1991c). The pre-Missoula gravels are discussed in PSPL (1982) and Fecht et al. (1987). 
Hanford formation. The informally designated Hanford formation consists of unconsolidated, glaciofluvial sediments that were deposited during several episodes of cataclysmic flooding during the Pleistocene Epoch. The sediments are composed of pebble to boulder-size gravel, fine- to coarse-grained sand, and silt. These sediments are divided into three facies: gravel dominated, sand-dominated, and silt-dominated (WHC 1992a). These facies are referred to as coarse-grained deposits, plane-laminated sand facies, and rhythmite facies, respectively (Baker et al. 1991). The silt-dominated deposits are also referred to as "Touchet" Beds, and the gravel-dominated facies generally correspond to the Pasco gravels.

The Hanford formation is thickest in the vicinity of the 200 Areas where it is up to 350 feet thick (WHC 1992a). The formation was deposited by cataclysmic flood waters that originated from glacial lake Missoula (Fecht et al. 1987, DOE 1988, Baker et al. 1991). The deposits are absent from ridges above approximately 1,180 feet above mean sea level, the highest level of cataclysmic flooding in the Pasco Basin (WHC 1991b).

Holocene Surficial Deposits. Holocene surficial deposits consist of silt, sand, and gravel that forni a $<16$-feet veneer across much of the Hanford Site. These sediments were deposited by colian and alluvial processes (WHC 1991b).

\section{REGIONAL GEOLOGIC STRUCTURE}

The Hanford Site is located within the Pasco Basin near the eastern edge of the Yakima Fold Belt. The Yakima Fold Belt consists of a series of segmented, narrow, asymmetric, east-west trending anticlines separated by broad synclines or basins that, in many cases, contain thick accumulations of Neogene- to Quaternary-aged sediments (DOE 1988, Smith et al. 1989). The Pasco Basin is one of the larger structural basins of the fold belt.

The northern limbs of the anticlines of the Yaikima Fold Belt generally dip steeply to the north or are vertical. The southern limbs generally dip at relatively shallow angles to the south. Thrust or high-angle reverse faults with fault planes that strike parallel or subparallel to the axial trends are principally found on the north sides of the anticlines. The amount of vertical stratigraphic offset associated with these faults varies (WHC 1991b).

Deformation of the Yakima Folds occurred under north-south compression and was contemporaneous with the eruption of the basalt flows. The fold belt was enlarging during the eruption of the Columbia River Basalt Group and continued to enlarge through the Pliocene, into the Pleistocene, and perhaps to the present (WHC 1991b).

The Pasco Basin is a structural depression bounded on the north by the Saddle Mountain anticline; on the west by the Umtanum Ridge, Yakima Ridge, and Rattlesnake Hills anticlines; and on the south by the Rattlesnake Mountain anticline. The Palouse slope, 
1 a west-dipping monocline, bounds the Pasco Basin on the east. The Pasco Basin is divided

2 into the Wahluke and Cold Creek synclines by the Gable Mountain anticline, the eastern 3 extension of the Umtanum Ridge anticline.

\section{4}

The Cold Creek syncline lies between the Umtanum Ridga-Gable Mountain uplift and the Yakima Ridge uplift and is an asymmetric and relatively flat-bottomed structure. The bedrock of the northem limb dips gently to the south, and the southem limb dips steeply to the north. The deepest parts of the Cold Creek syncline, the Wye Barricade depression, and the Cold Creek depression, are located approximately 7.5 miles southeast of the 200 Areas and just west-southwest of the 200 West Area, respectively (Tallman et al. 1979).

\section{LOCAL GEOLOGY}

The depth to the top to the Elephant Mountain Member basalt in the 200 East Area ranges from approximately 280 feet in the northern part to approximately 520 feet in the southern part. Overlying the basalt are the suprabasalt sediments of the Ringold Formation, Hanford formation, and Holocene surfical deposits. The Plio-Pleistocene unit, early "Palouse" soil, and the Pre-Missoula gravels are absent in the 200 East Area (WHC 1992a). The following discussion of the local geology focuses on the suprabasalt sediments within the 200 East Area. A map depicting the geology within one mile of the 200-E Chemical Drain Field is provided as Figure H-6. A local cross section has also been included for more detailed information. The line of cross-section is shown on Figure $\mathrm{H}-7$ and the cross-section is provided on Figure H-8.

\section{Ringold Formation}

The Ringold Formation unconformably overlies the Elephant Mountain Member basalt in the southern two thirds of the 200 East Area, but is absent in the northern part. The Ringold Formation thickens and dips to the south, southeast, and southwest towards the axis of the Cold Creek syncline (WHC 1992a). Unit A, the lower mud sequence, and unit E are the only Ringold Formation units present in the 200 Areas.

The lowest unit of the Ringold Formation is fluvial gravel unit A. Unit A thickens and dips towards the south in the direction of the Cold Creek syncline. Within the 200 East Area unit A ranges from 0 feet thick in the northern part to approximately 100 feet thick near the southern boundary. Unit A is generally described as a clast-supported granule to cobble gravel with a sandy matrix. Clast composition is variable, with basalt, quartzite, porphyritic volcanics, and greenstone being the most common. Clasts of silicic plutonic rocks, gneiss, and volcanic breccias can also be found. Associated sands are generally quartzo-feldspathic with basalt content ranging from 5 percent to 25 percent (WHC 1992a).

The lower mud sequence overlies unit $A$ and also dips and thickens towards the south. 
1 The thickness of the lower mud sequence ranges from 0 feet in the northem part to approximately 50 feet near the southern boundary of the 200 East Area. The lower mud

3 sequence is composed of overbank and lacustrine deposits. The overbank deposits consist of 4 laminated to massive silt, silty fine-grained sand, and palcosols containing variable amounts

5 of pedogenic calcium carbonate. Plane laminated to massive clay with thin silt and sand 6 interbeds characterize the lacustrine deposits. The lacustrine deposits contain some soft7 sediment deformation (WHC 1992a).

Unit E locally overlies the lower mud sequence in the southwest comer of the 200 East Area and in the vicinity of the Grout Treatment Facility. The unit appears to be absent from the northern and central parts of the 200 East Area. The unit thickens towards the separations area between the 200 East and 200 West Areas. The thickness of unit E ranges from 0 feet in the northern and central parts of the 200 East Area to approximately 90 feet southwest of the 200 East Area. Unit E is a clast-supported granule to cobble gravel, similar to unit A. Locally, strata typical of the fluvial sand and overbank facies associations may be encountered within unit E (WHC 1992a).

\section{Hanford formation}

In the 200 East Area, the Hanford formation consists predominately of graveldominated and sand-dominated facies. Informally, the Hanford formation can be divided into the upper gravel sequence, middle sand sequence, and lower gravel sequence (WHC 1992a). Because of the variability of Hanford formation sediments, contacts between these sediments can be difficult to distinguish, especially where the sandy sequence is missing and the upper gravel directly overlies the lower gravel. In the 200 East Area, the Hanford formation overlies the Ringold Formation in the southern two-thirds of the area and in the northern part, the Hanford formation directly overlies the Elephant Mountain Member basalt where the Ringold Formation is absent.

The lower gravel sequence consists of coarse-grained basaltic sand and granule to boulder gravel. Other clast types include Ringold and Plio-Pleistocene rip-ups, granite, quartzite and gneiss (WHC 1992b). Discontinuous intervals dominated by the sanddominated facies and localized horizons of silt-dominated deposits are also present within the lower gravel sequence. The lower gravel sequence ranges in thickness from approximately 0 to 134 feet. The lower gravel sequence is absent in the east central part of the 200 East Area (WHC 1992a).

The middle sand sequence overlies the lower gravel sequence and is dominated by deposits of the sand-dominated facies, consisting of fine- to coarse-grained sand and granule gravel displaying plane lamination and bedding. Intercalated horizons typical of both the gravel-dominated and silt-dominated sequences also occur within the middle sand sequence, with the gravel sequence more abundant in the northern part and the silt sequence more abundant in the southern part of the 200 East Area. The middle sand sequence in the 200 
DOE/RL-94-24, Rev. 0

06/94

200-E Chemical Drin Field

1 East Area ranges in thickness from 0 to 275 feet. The middle sand unit thins and pinches

2 out to the north, east, and west of the 200 East Area (WHC 1992a).

3

4

5

6

The upper gravel sequence overlies the middle sand sequence in the southern part of the 200 East Area and the lower gravel unit in the northem part of the 200 East Area. Deposits comprising the upper gravel sequence are typical of the gravel-dominated facies. Lenticular horizons of sand-dominated and silt-dominated facies are encountered locally in the upper gravel sequence. The thickness of the upper gravel sequence ranges from 0 to 60 feet. The upper gravel sequence thickens to the north and is absent in the central part of the 200 East Area.

\section{Holocene Surficial Deposits}

Holocene surficial deposits consist of silt, very fine- to medium-grained sand and gravel that form a $<33$ feet veneer across much of the Hanford Site. These sediments were deposited by a combination of eolian and alluvial processes which have produced sheet sands which blanket the surface. Locally most of the surfical deposits have been removed by construction activities (WHC 1992a).

\section{REGIONAL HYDROGEOLOGY}

The hydrogeology of the Pasco Basin has been broadly characterized as consisting of four primary hydrogeologic units (DOE 1988). These units correspond to the upper three formations of the Columbia River Basalt Group (Grande Ronde Basalt, Wanapum Basalt, and Saddle Mountains Basalt) and the suprabasalt sediments. The basalt aquifers consist of the flood basalts of the Columbia River Basalt Group and relatively minor amounts of intercalated fluvial and volcaniclastic sediments of the Ellensburg Formation. Confined zones in the basalt aquifers are present in the sedimentary interbeds and/or interflow zones that occur between dense basalt flows. The main water-bearing portions of the interflow zones are networks of interconnecting vesicles and fractures of the basalt flow tops and bottoms (DOE 1988).

The uppermost aquifer is part of a flow system that is local to the Pasco Basin, as are the uppermost basalt interbed aquifers (Gephart et al. 1979, DOE 1988). The uppermost aquifer system is regionally unconfined and occurs within the glaciofluvial sands and gravels of the Hanford formation and the fluvial/lacustrine sediments of the Ringold Formation. Confined to semi-confined aquifers of more limited extent also occur in the suprabasalt sediments of the Pasco Basin. These confined zones are generally located within the local flow system, between the unconfined aquifer and the underlying basalt surface. Groundwater in these aquifer systems is most likely recharged and discharged locally. Deeper in the basalt, interbed aquifer systems are part of the regional, or interbasin, flow system, which extends outside the margins of the Pasco Basin (DOE 1988). A water table map of the 
DOE/RL-94-24, Rev. 0

06/94

200-E Chomical Drain Fiald

1 Hanford Site is provided as Figure H-9.

\section{LOCAL HYDROGEOLOGY}

The primary hydrostratigraphic units in the 200 East Area are the confined aquifer system of the Saddle Mountain Basalt Formation and Ellensburg Formation, and the unconfined to confined aquifer system of the Ringold Formation and the Hanford formation. The following discussion focuses on the hydrogeology of the suprabasalt sediments.

In the vicinity of the 200 East Area, the vadose zone is primarily composed of the Ringold gravel unit $A$ through the central and southern portions of the area and the Ringold lower mud sequence to the east near the 216-B-3 Pond. In the north part of 200 East where the Ringold Formation is discontinuous, the vadose zone is dominantly composed of the Hanford formation (DOE-RL 1993a). The vadose zone ranges from about 317 feet thick near the southwestern part of the 200 East Area to 1230 feet thick in the vicinity of the 216B-3 Pond (DOE-RL 1993a).

The uppermost aquifer system comprises the unconfined aquifer, but also includes localized semiconfined and confined areas. The hydrostratigraphy of the unconfined aquifer in the 200 East Area is relatively complex because of depositional and erosional history of the geologic units (DOE-RL 1993a). The unconfined aquifer in the 200 East Area occurs within the Ringold Formation and Hanford formation. The base of the unconfined aquifer is the top of the lower mud sequence along the southern and eastern areas of the 200 East Area. Along the northern parts of the 200 East Area, the base of the unconfined aquifer is the top of the Elephant Mountain Member basalt. The thickness of the unconfined aquifer varies from 0 feet in the northeastern corner where basalt extends above the water table to more than 262 feet to the south (DOE-RL 1993a).

The 200 East Area water table is relatively flat and gradients are difficult to discern. Flow directions from the 200 East Area are the result of hydraulic effects of the B-Pond system groundwater mound situated on the east side of the 200 East Area. The B-Pond mound deflects eastward groundwater flow across the Hanford Site. Other miscellaneous waste stream discharges in the 200 East Area may have minor localized effects on groundwater flow patterns. Contaminant plume geometries provide some indication of flow directions where gradients are relatively flat. For the unconfined aquifer, groundwater flow away from the 200-East Area is bifurcated northward through the gap between Gable Mountain and Gable Butte; or to the east-southeast across the site and ultimately to the Columbia River. 
1 A semiconfined to confined aquifer is observed in the vicinity of the 216-B-3 Pond 2 where the groundwater occurs in the Ringold unit A gravels and is confined by the lower 3 mud sequence. This aquifer appears to be near only the 216-B-3 Pond system (DOE-RL 4 1993a). 
DOE/RL-94-24, Rev. 0

$06 / 94$

200-E Chemical Drain Field

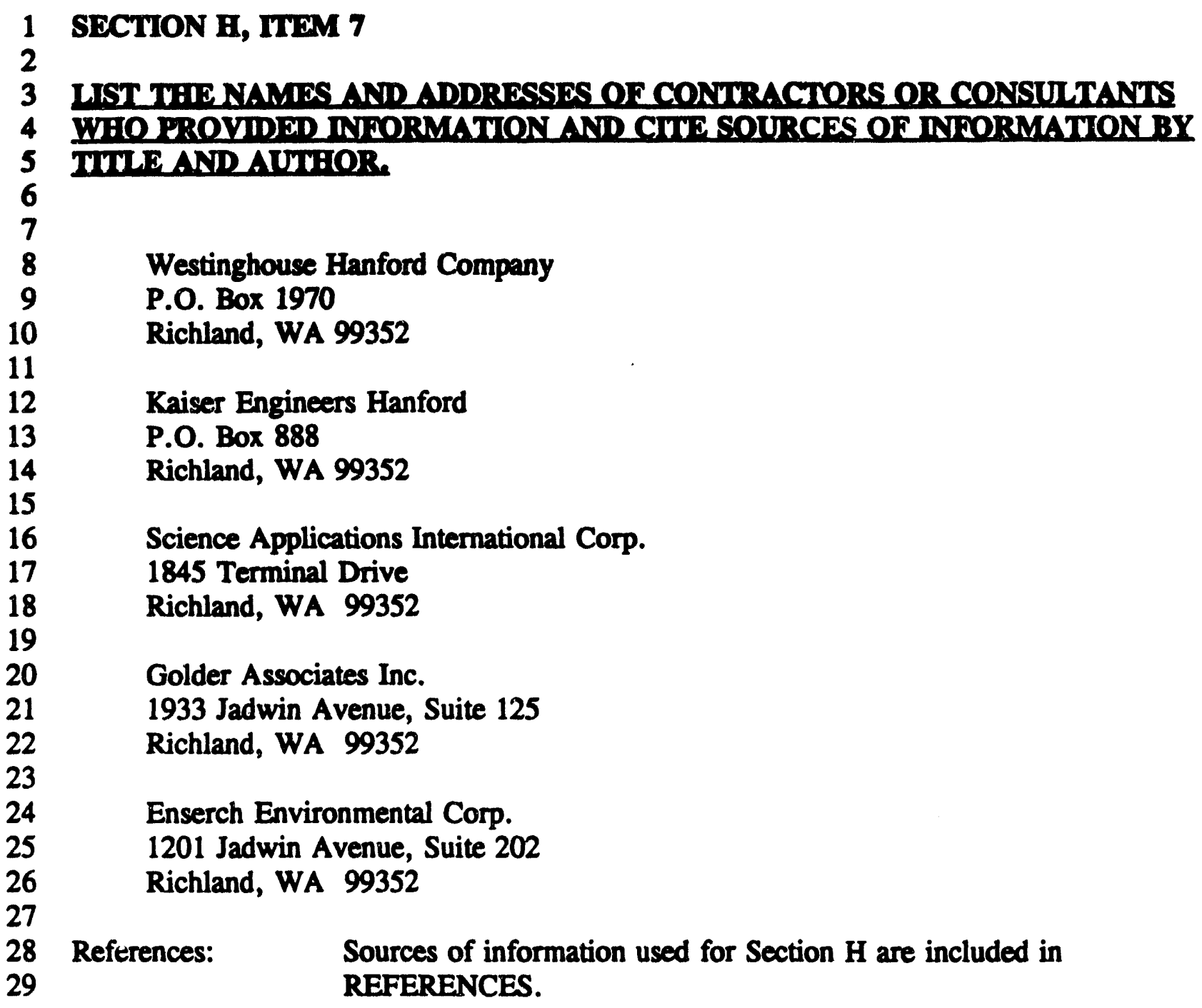

Kaiser Engineers Hanford

P.O. Box 888

Richland, WA 99352

Science Applications International Corp.

1845 Terminal Drive

Richland, WA 99352

Golder Associates Inc.

1933 Jadwin Avenue, Suite 125

Richland, WA 99352

Enserch Environmental Corp.

1201 Jadwin Avenue, Suite 202

Richland, WA 99352

Sources of information used for Section $\mathrm{H}$ are included in REFERENCES. 


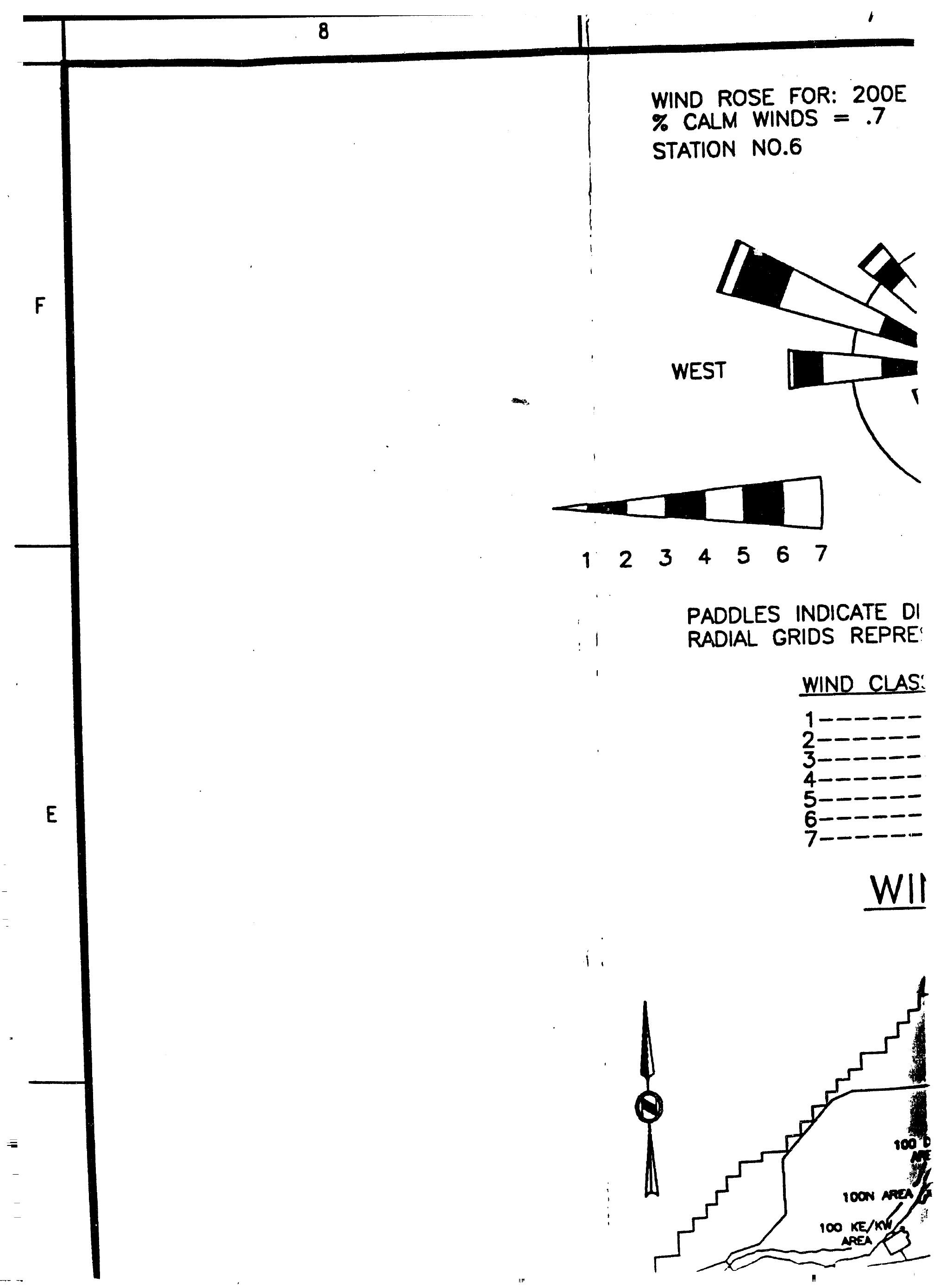


ROSE FOR: 200E AREA

$M$ WINDS $=.7$

PERIOD COVERED

N NO.6

\section{NOPTH}

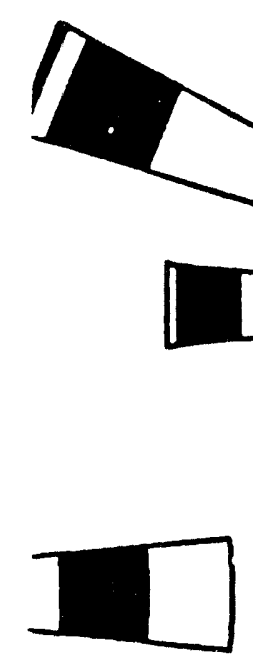

567

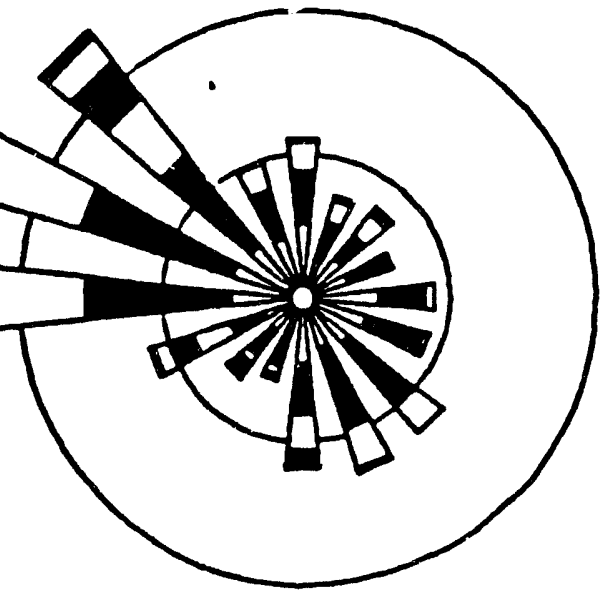

SOUTH
EAST

$1 / 93$

JLES INDICATE DIRECTION WIND IS COMING FROM.

AL GRIDS REPRESENT $5.0 \%$ AND $10.0 \%$ OCCURRENCE.

WIND CLASS

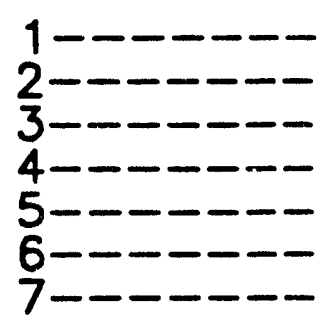

MILES/HOUR

$>1.0=3.0$

$8.0-12.0$

$13.0-18.0$

$19.0-24.0$

$25.0-31.0$

\section{WIND ROSE}

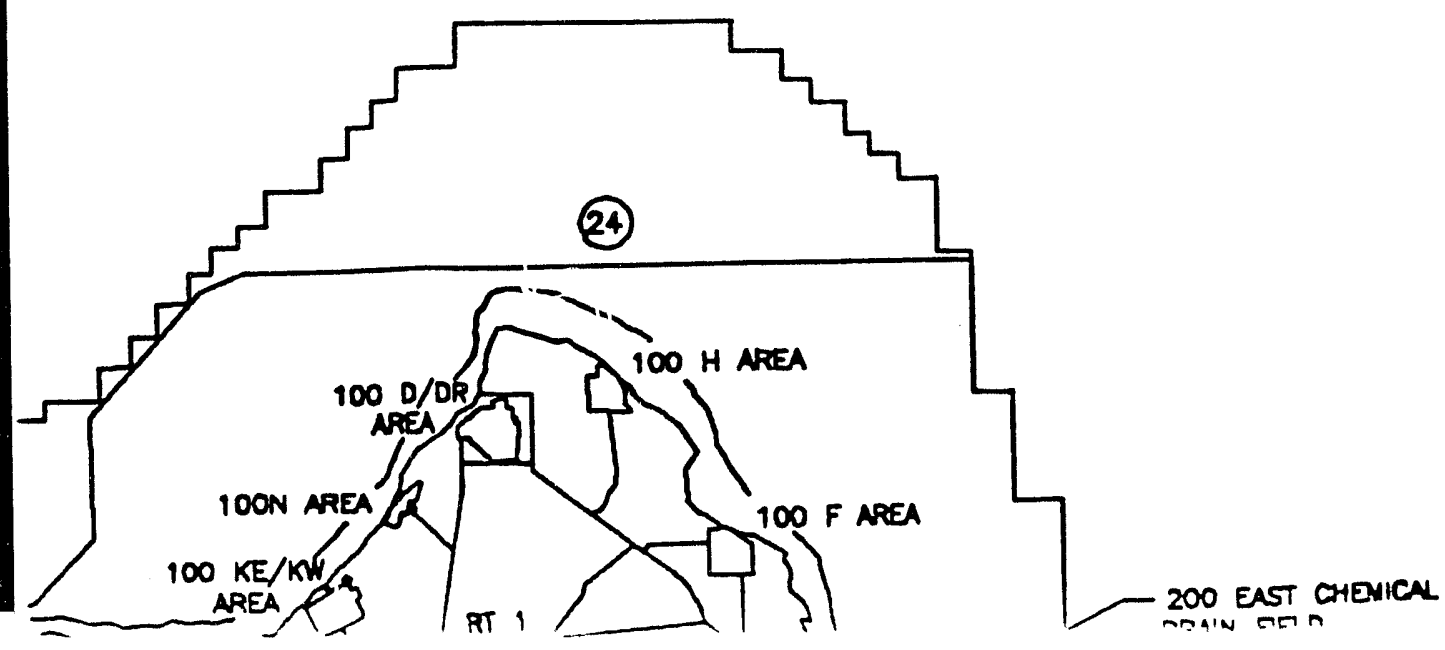




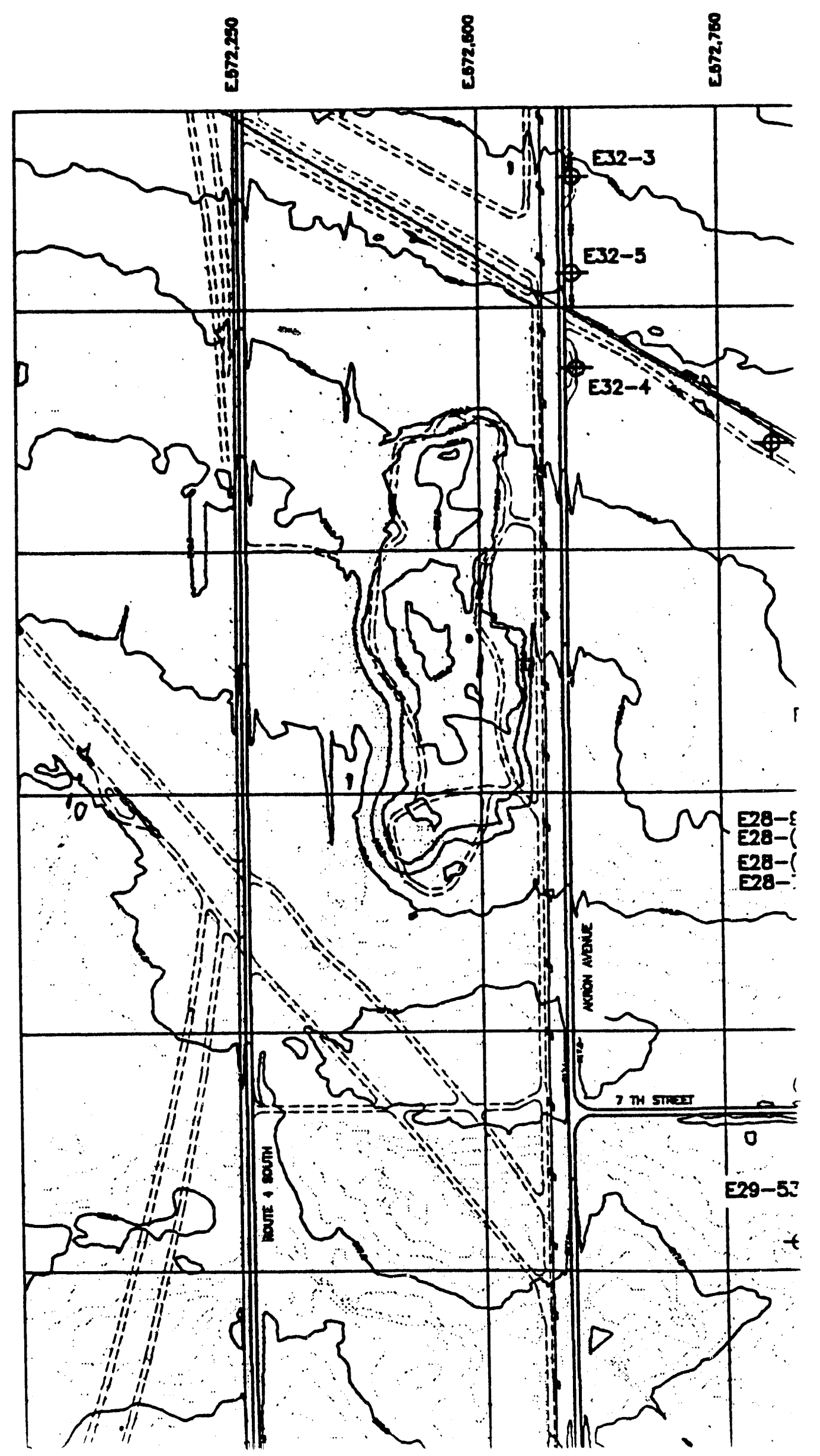




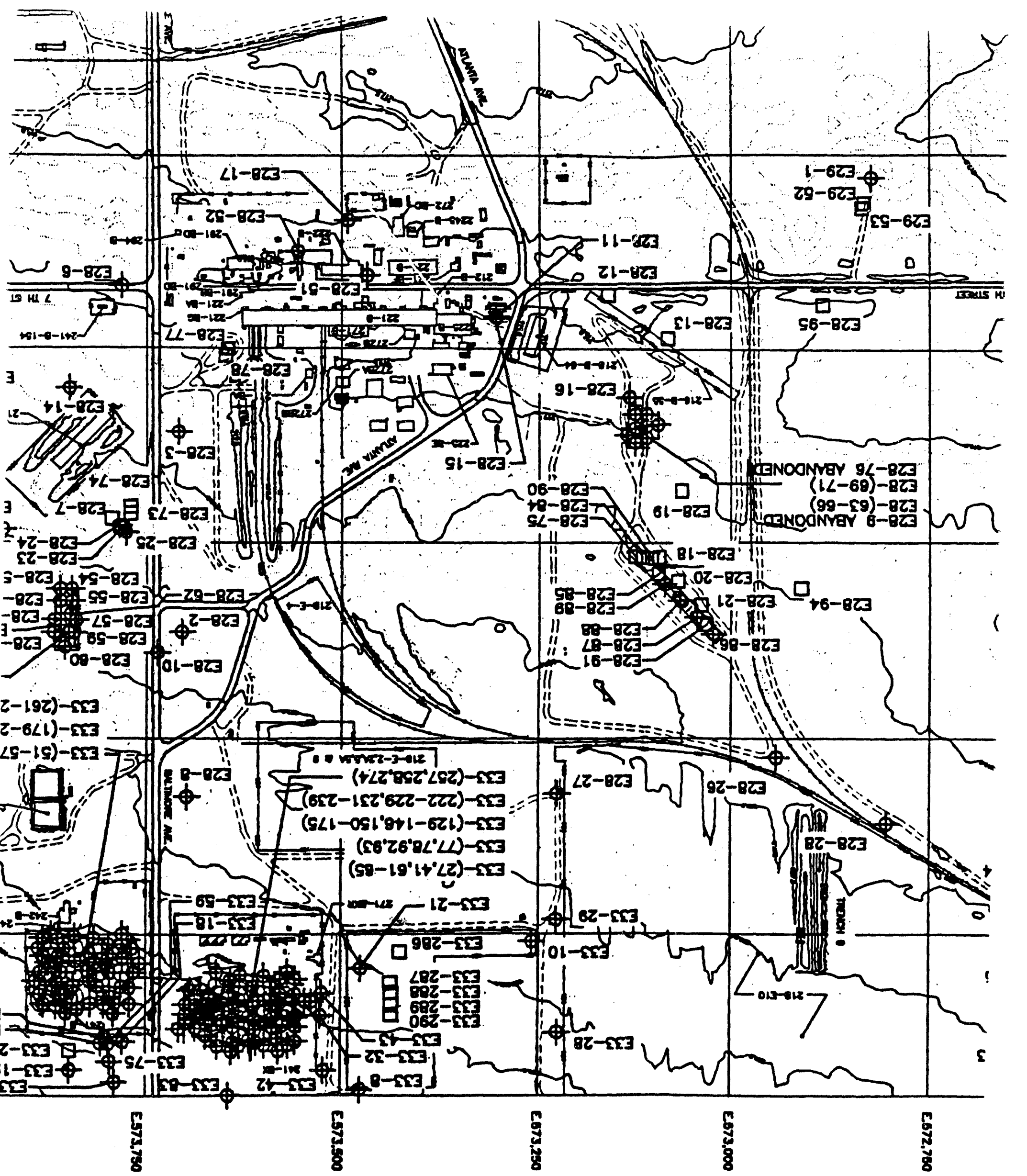




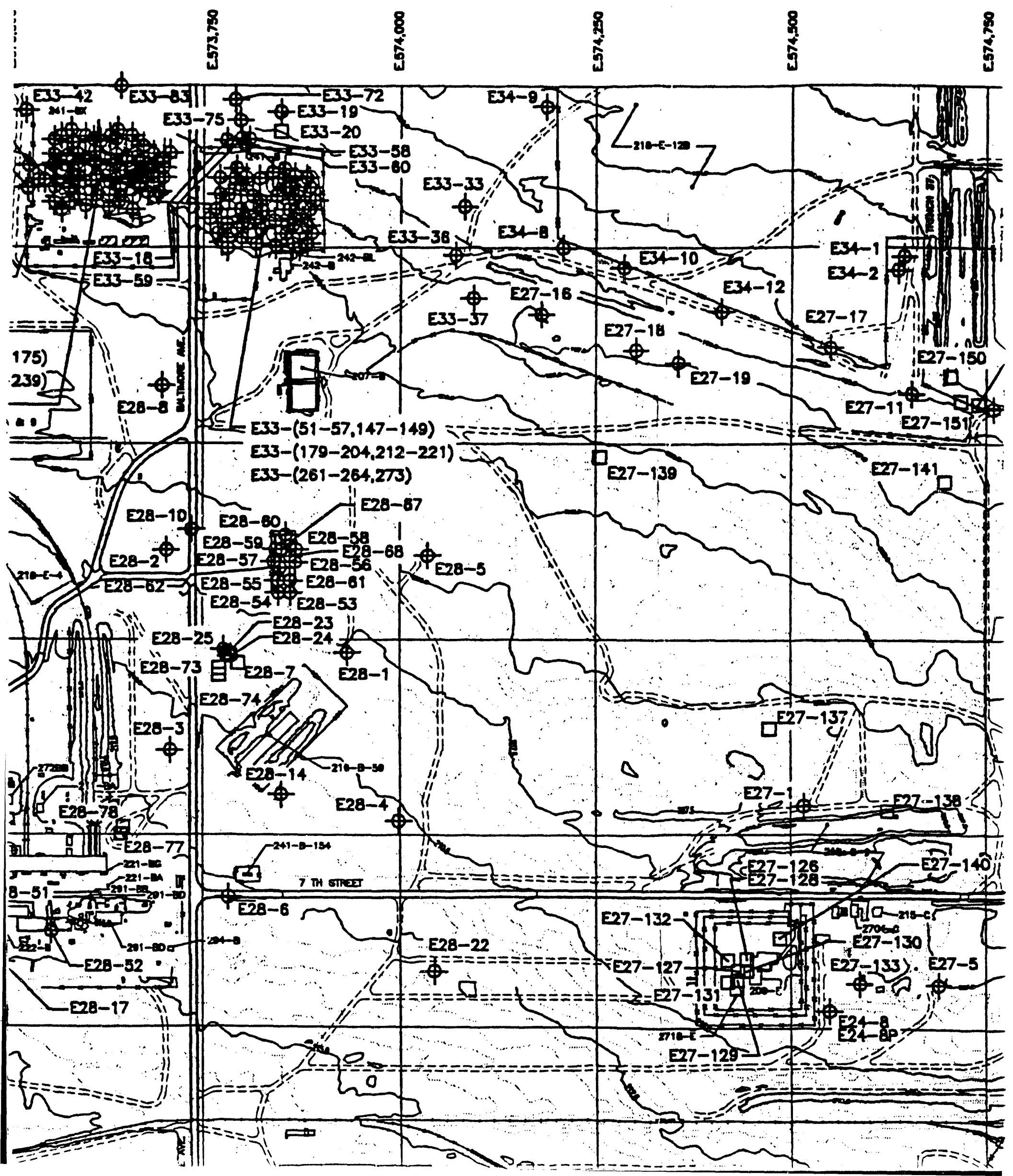



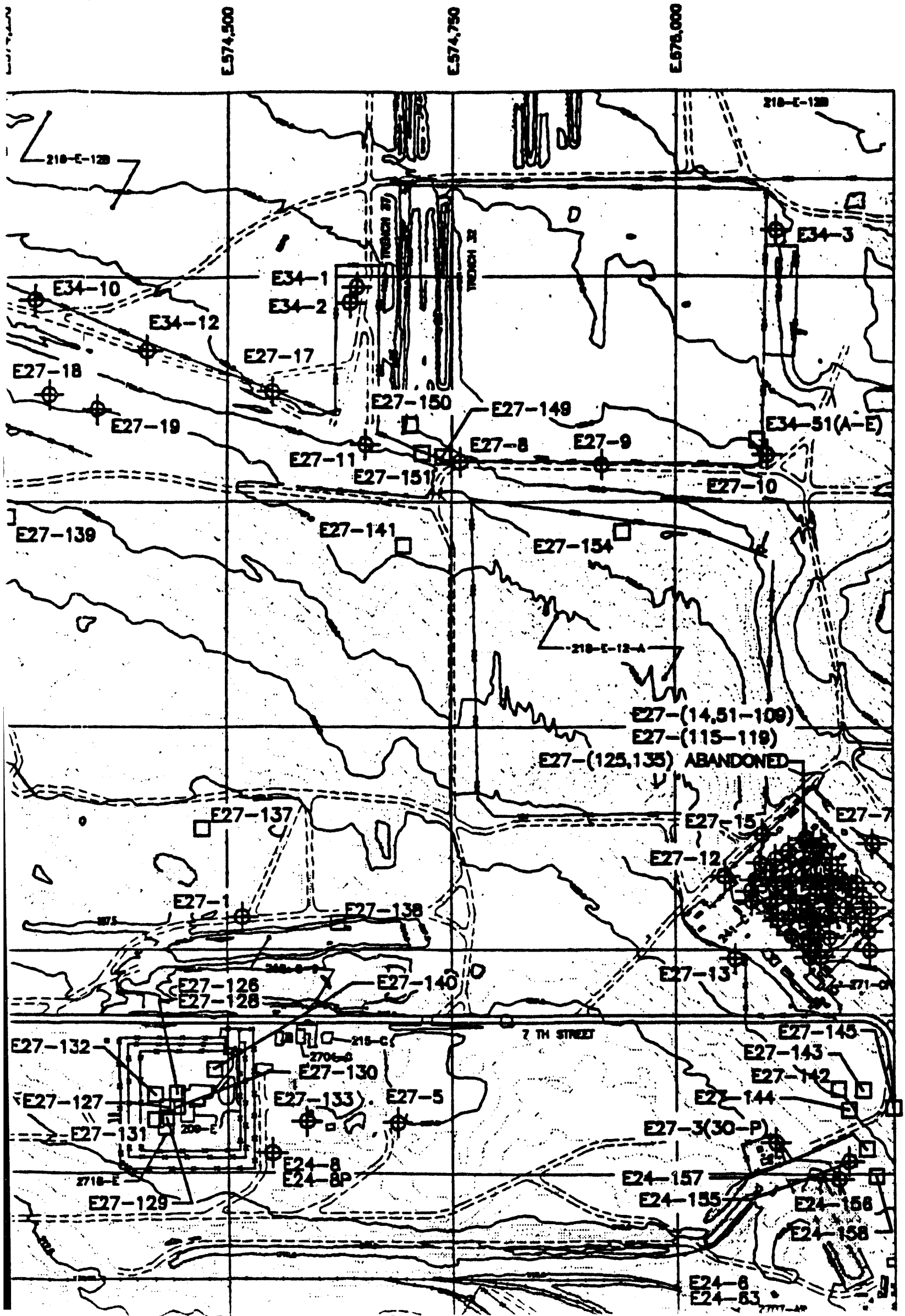

0.137250

M.137,000

N.136,750

N.130,500

N.136,250 


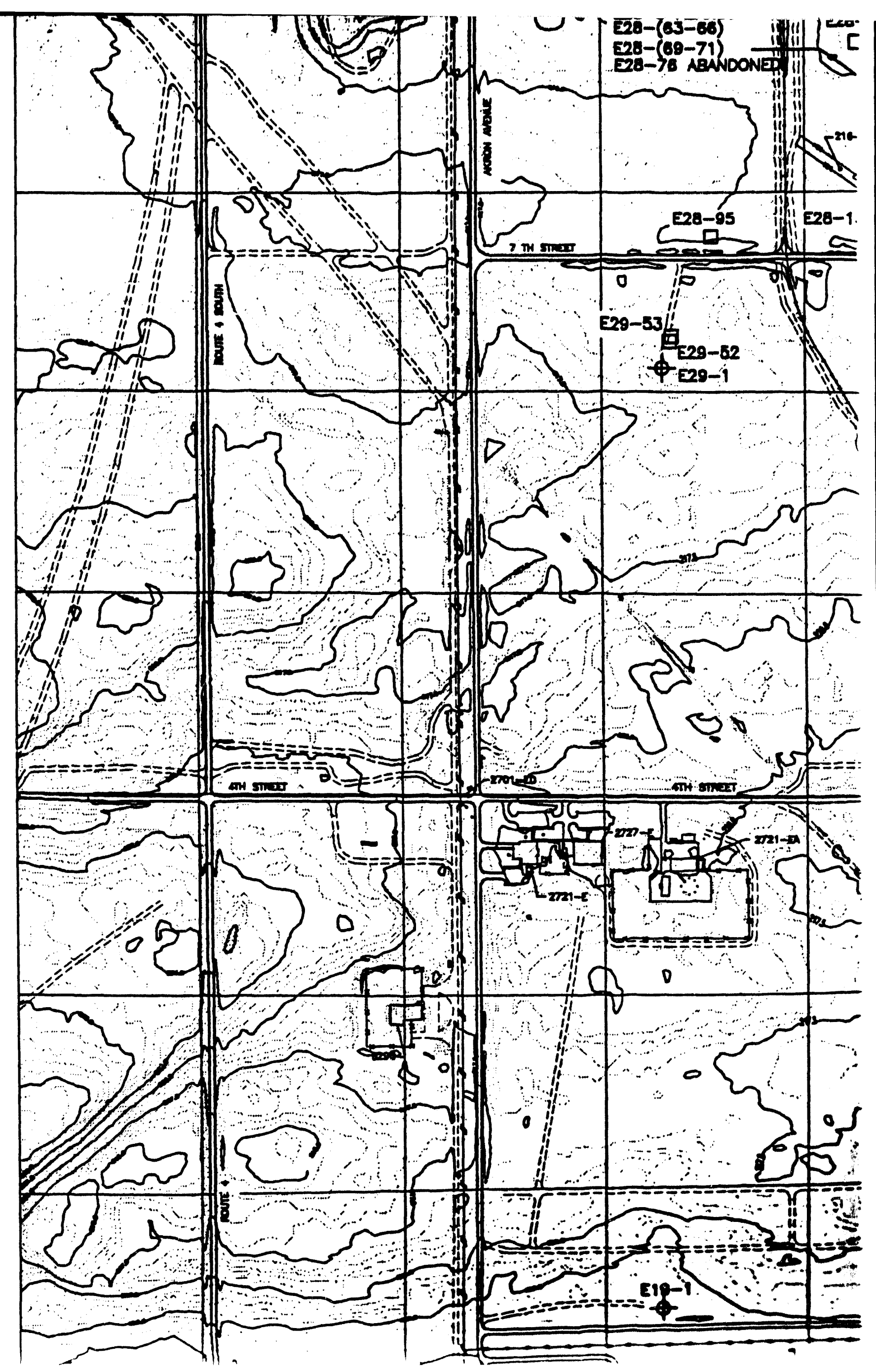




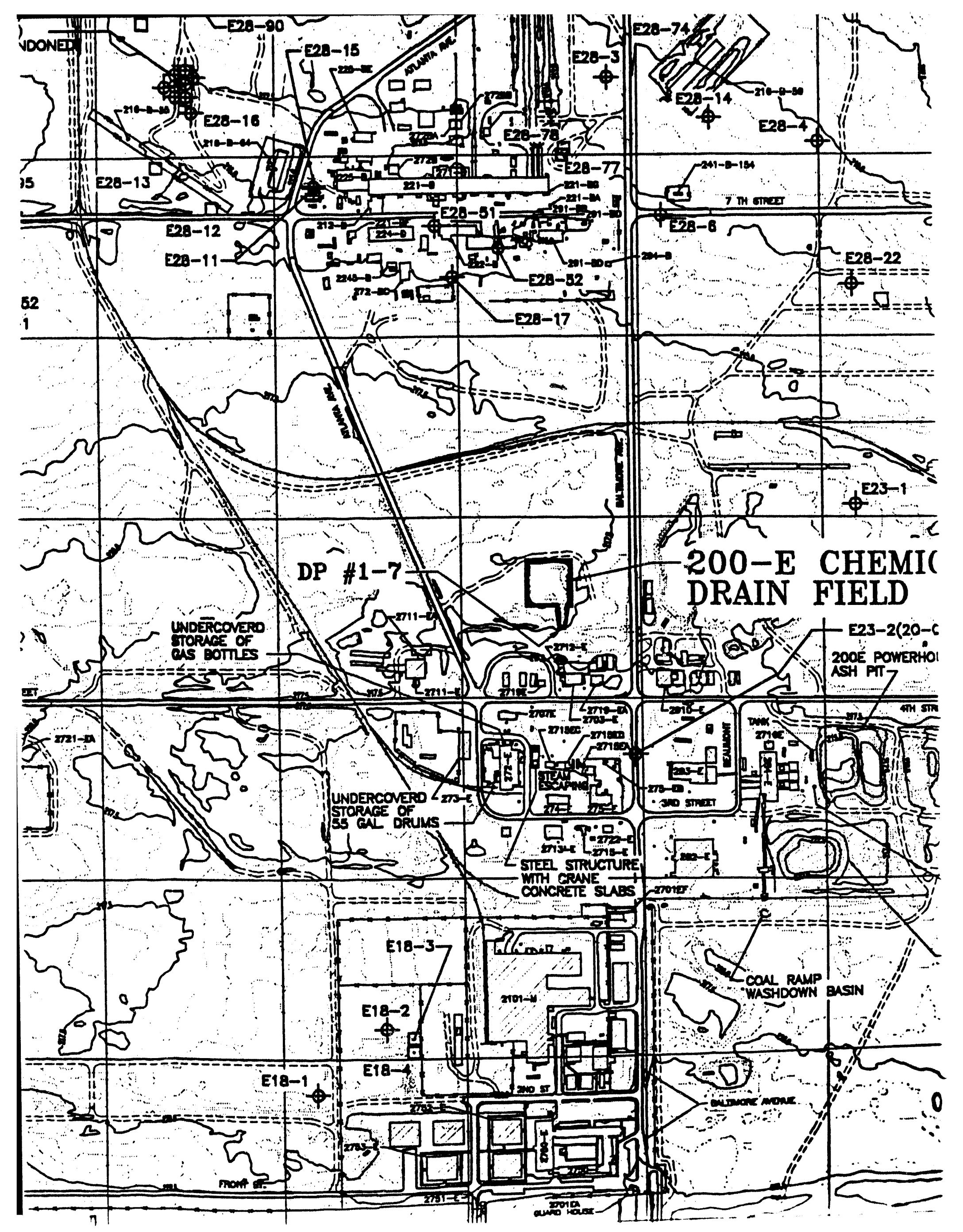




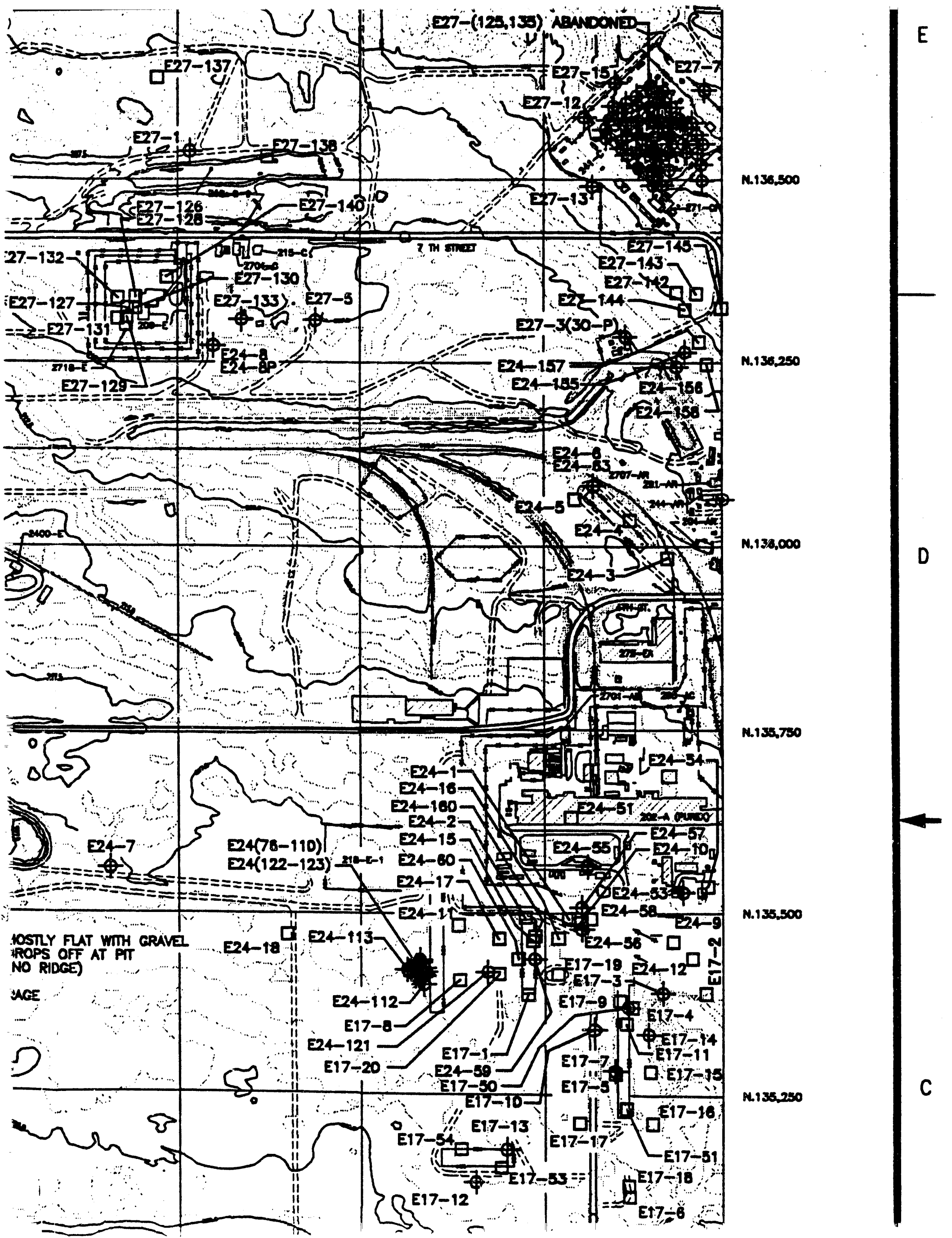




\section{KEY PLAN SCALE: NONE}

\section{LEGEND}

\begin{tabular}{|c|c|c|}
\hline COORDINATES & 8 & $\begin{array}{l}\text { BUILDINGS } \\
\text { \& TOWERS }\end{array}$ \\
\hline ATE COORDINATES & $242-A$ & BUILDING NUMBER \\
\hline : (METERS) & ב & MOBILE OFFICES \\
\hline :ONTOUR & $\begin{array}{c}E 27-1 \\
\phi^{-1}\end{array}$ & WELL \\
\hline ) & 口 & ABANDONED WELL \\
\hline.$O A D$ & & TANKS \\
\hline & $216-A-42$ & CRIB \\
\hline & $\begin{array}{c}218-E-10 \\
D P\end{array}$ & $\begin{array}{l}\text { BURAL GROUND } \\
\text { DISCHARGE POINT }\end{array}$ \\
\hline
\end{tabular}

VING,MISC FENCES

$N$

GROUND FENCES)

ENCES

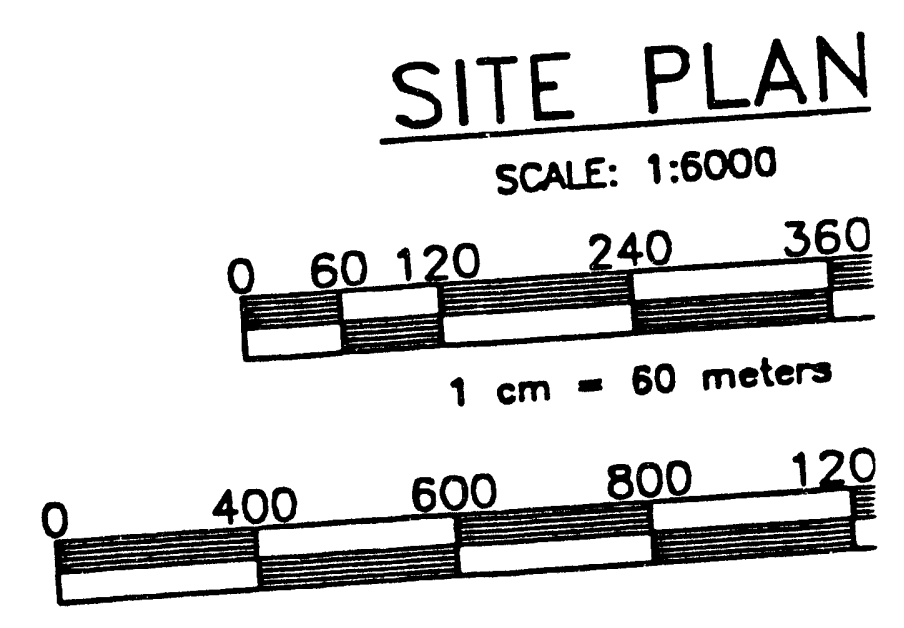

ES

39. THE ORIGINAL TOPOGRAPHIC MAP WAS PREPARED ACCURACY STANDARDS.

ATE ARE LOCATED IN THE WESTINGHOUSE

AND H-2-79477 SHEET 1 THRU 37.

DORDINATE SYSTEM AS DEFINED GY THE WTHIN THE WASHINGTON COORDINATE SYSTEM, (EASTINGS) AND Y (NORTHINGS) COORDINATES.

STATE PLANE COORDINATES ARE SHOWN IN METERS.

POINT NORTHEAST OF THE 400 AREA $\pi$

BITE WORK SUCH AS WELLS AND BURLAL 


\section{SITE PLAN \\ SCALE: 1:6000}
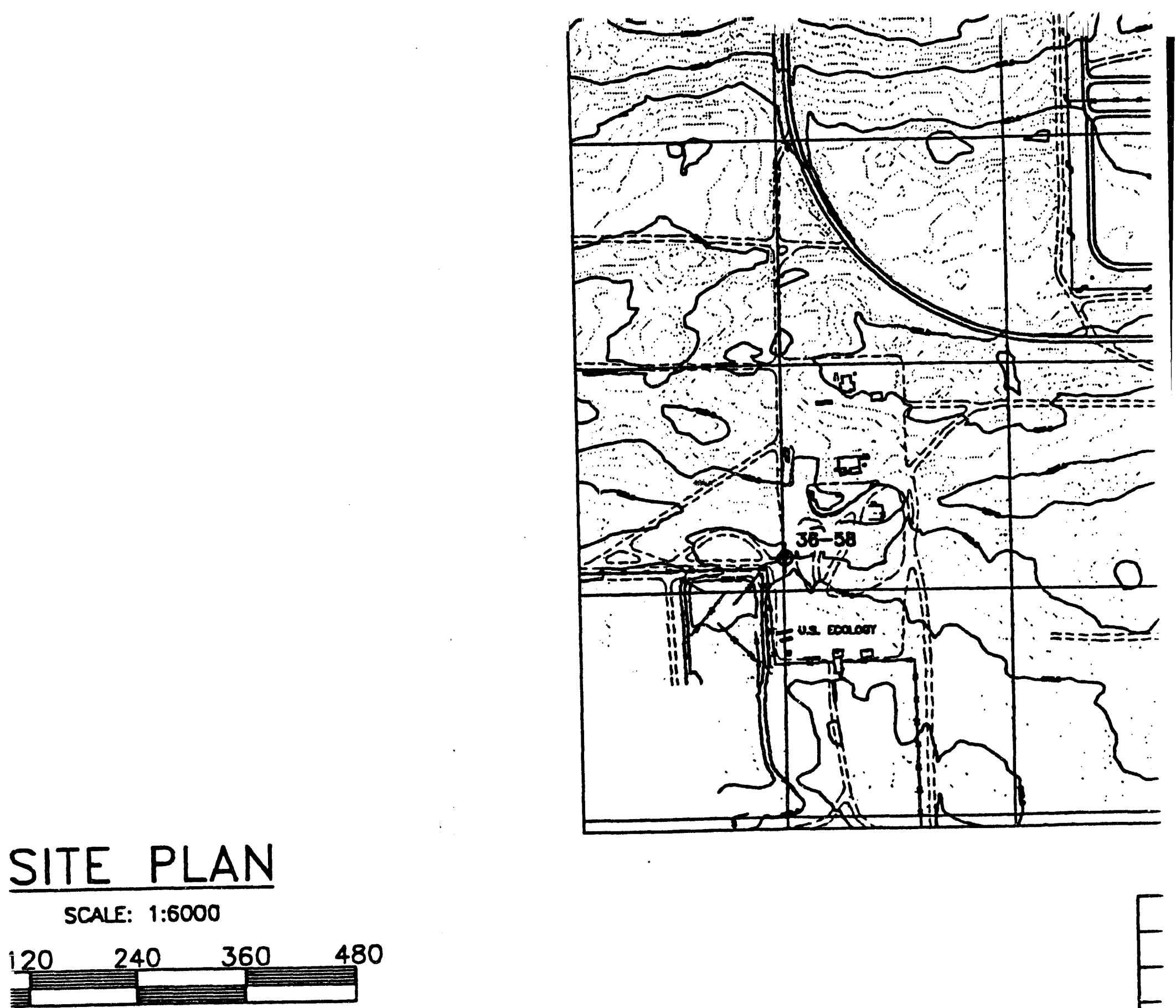

$1 \mathrm{~cm}=60$ meters

$\begin{array}{lllll}300 \quad 800 \quad 1200 \quad 1600 \quad 2000 & \text { FEET }\end{array}$
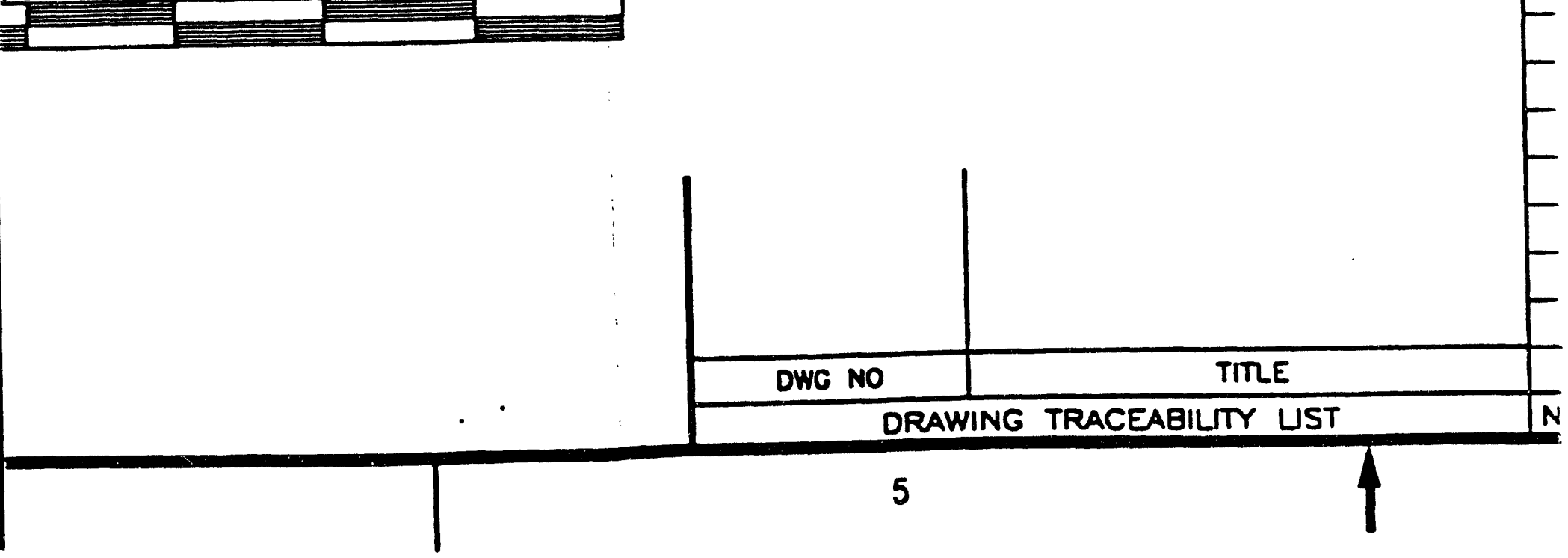


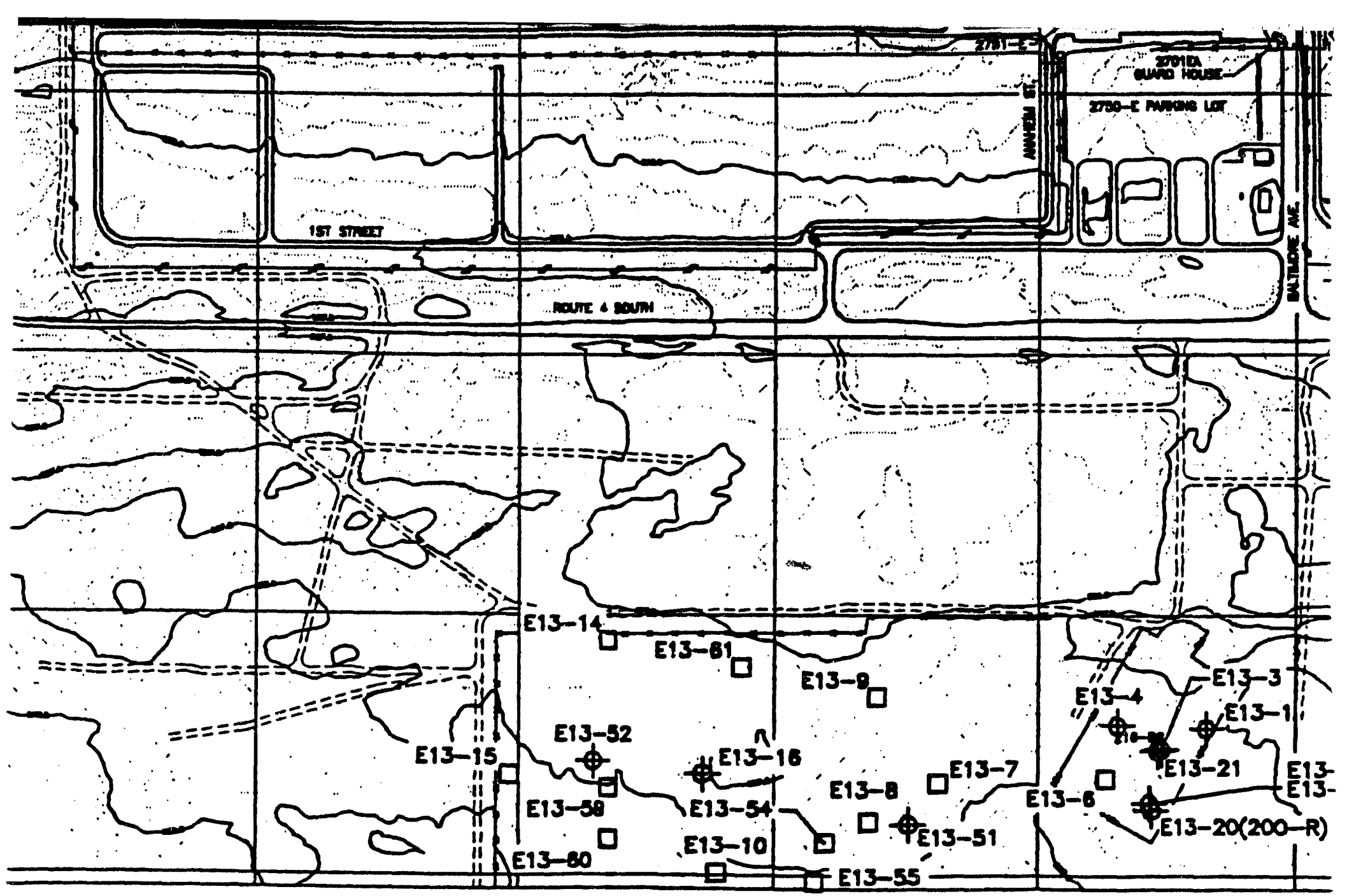

\begin{tabular}{|c|c|c|c|}
\hline $\mathrm{H}-13-000205$ & 200 AREA TOPOGRAPHIC MAP & & \\
\hline $\mathrm{H}-13-000206$ & 200 AREA TOPOGRAPHIC MAP & & \\
\hline $\mathrm{H}-13-000207$ & 200 AREA TOPOGRAPHIC MAP & & \\
\hline$H-13-000213$ & 200 AREA TOPOGRAPHIC MAP & & \\
\hline $\mathrm{H}-13-000214$ & 200 AREA TOPOGRAPHIC MAP & & \\
\hline $\mathrm{H}-13-000215$ & 200 AREA TOPOGRAPHIC MAP & & \\
\hline $\mathrm{H}-13-000221$ & 200 AREA TOPOGRAPHIC MAP & & \\
\hline $\mathrm{H}-13-000222$ & 200 AREA TOPOGRAPHIC MAP & & \\
\hline $\mathrm{H}-13-000223$ & 200 AREA TOPOGRAPHIC MAP & & \\
\hline$H-13-000229$ & 200 AREA TOPOGRAPHIC MAP & & \\
\hline $\mathrm{H}-13-000230$ & 200 AREA TOPOGRAPHIC MAP & & \\
\hline $\mathrm{H}-13-000231$ & 200 AREA TOPOGRAPHIC MAP & nev & ascripinan \\
\hline REF NUMBER & TILE & $m$ & \\
\hline \multicolumn{2}{|r|}{ REFERENCES } & & \\
\hline NEXT USED ON & $H-13-000200$ & CADFILE & N000086A \\
\hline
\end{tabular}




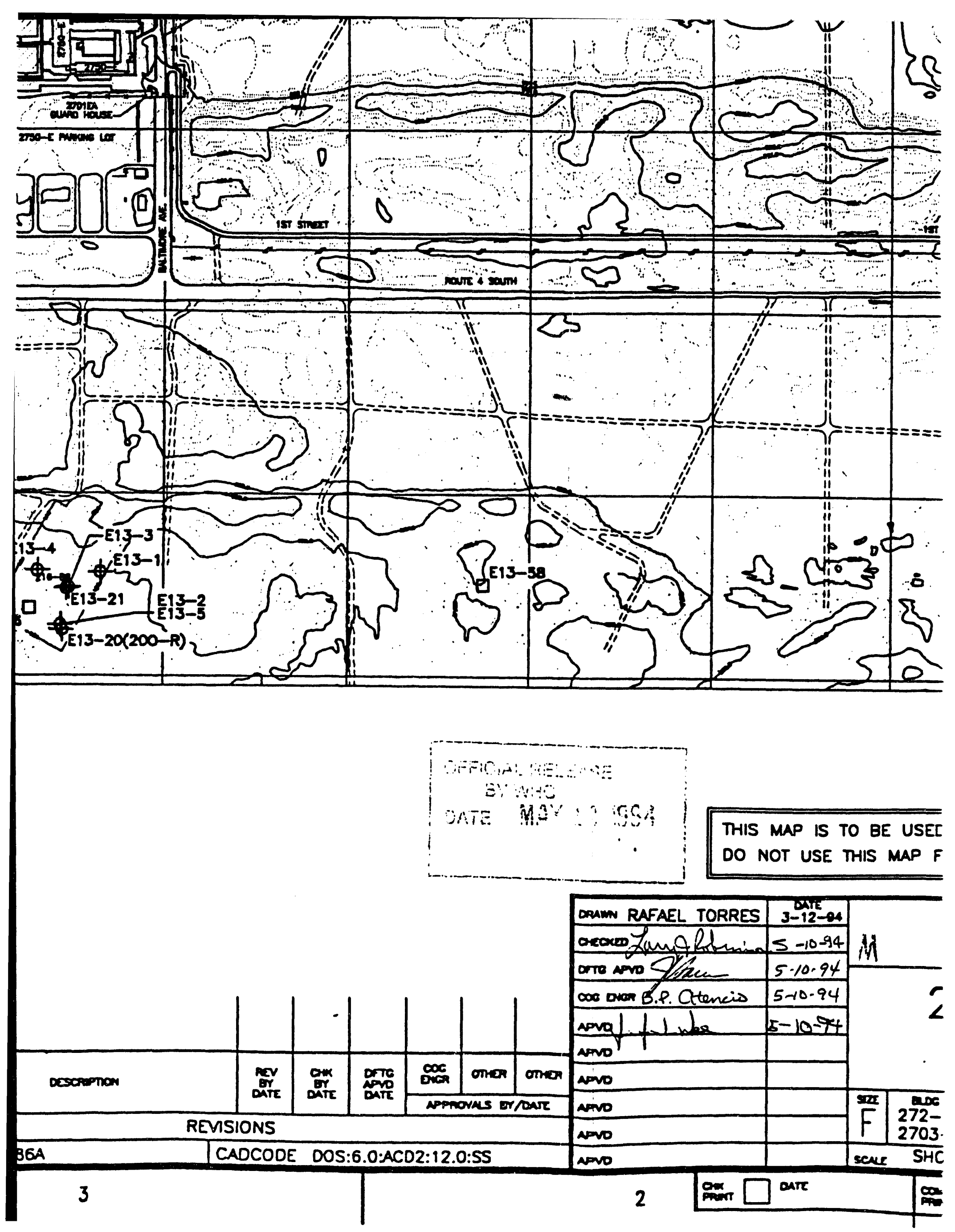




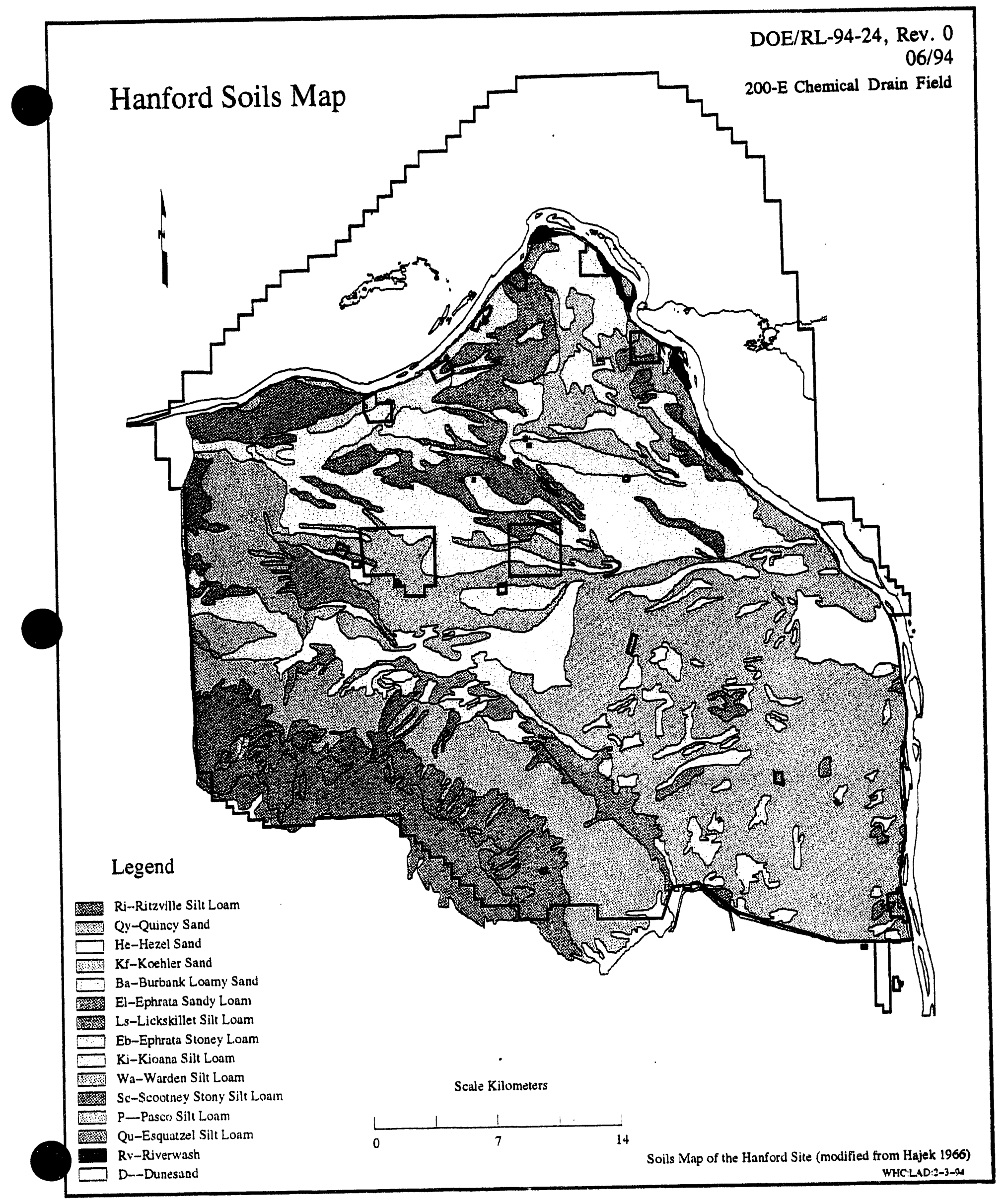

Figure H-1. Hanford Soils Map. 


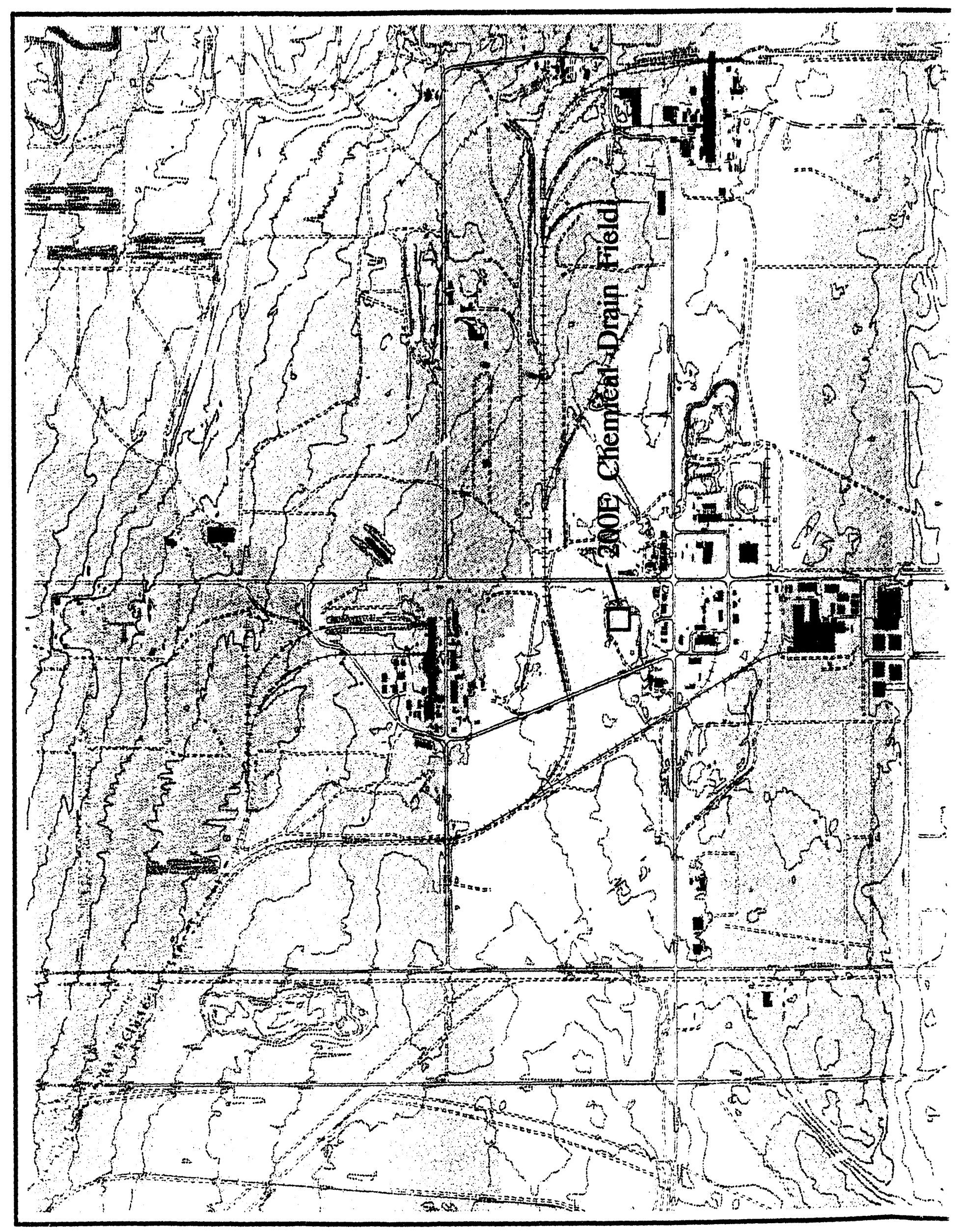




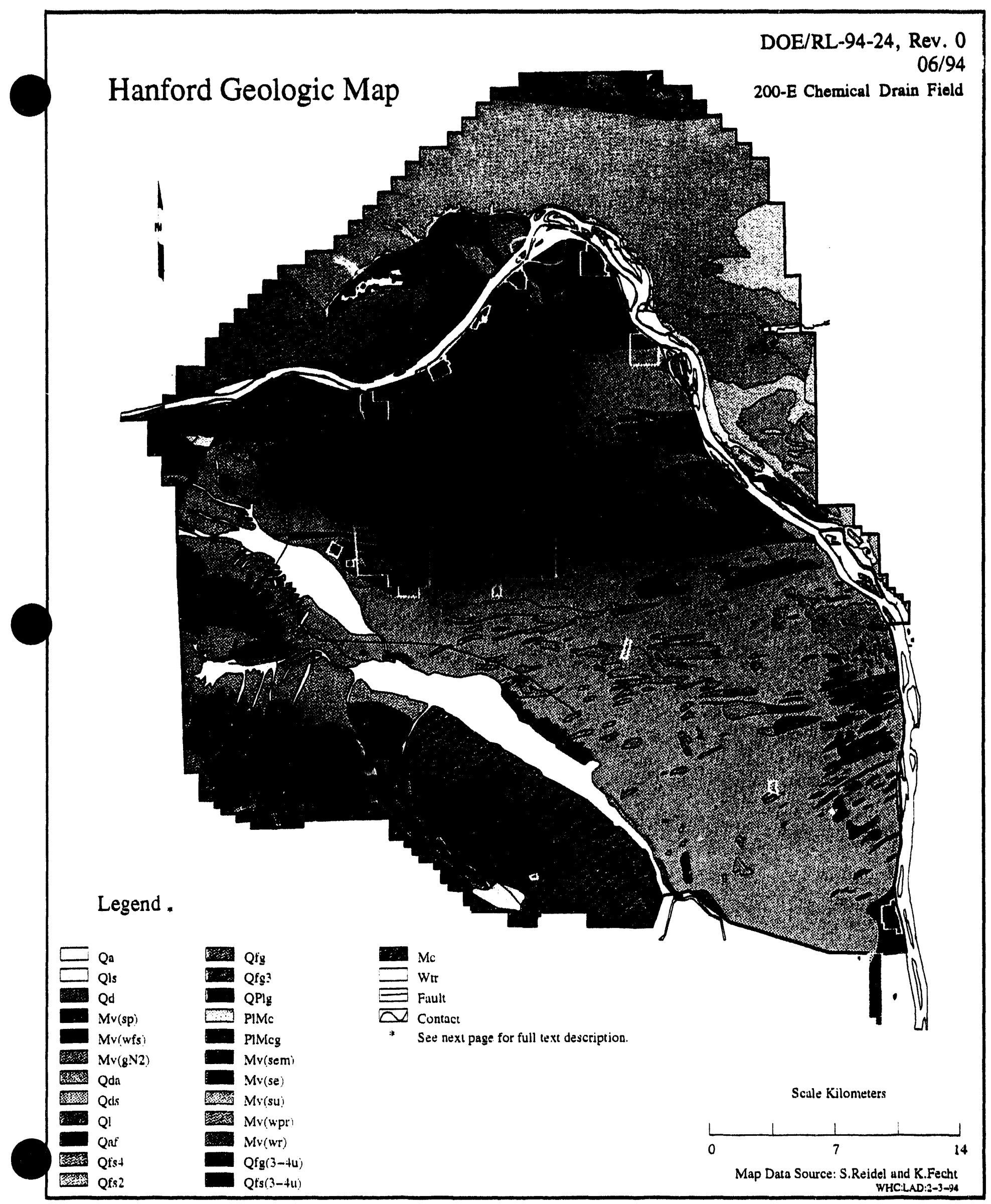

Figure H-3. Hanford Geologic Map. 


\section{Legend}

DOE/RL-94-24, Rev. 0

06/94

200-E Chemical Drain Field

Qa-Alluvium (Holo.-Pleis.)

Qls-Mass-wasting deposits (Holo.-Pleis.)

Qd--Dune sand (Holocene)

Mv(sp)-Saddle Mt Basalt, Pomona Mbr (M. Mio.)

Mv(wfs)-Wanapum Basalt. Frenchman Spr. Mbr (M. Mio.)

$\mathrm{Mv}(\mathrm{gN} 2)-G$ rande Ronde Basalt, U. flow-normal pol. (M. Mio.)

Qda-Dune sand. active (Holocene)

Qds-Dune sand, stabilized (Holocene)

Q1-Loess (Holocene to Pleistocene)

Qaf-Alluvial fans (Holo.-Pleis.)

Qfs4-Outburst flood dep.(Pleis.), silt \& sand, youngest

Qfs2-Outburst flood dep.(Pleis.), silt \& sand, 2nd oldest

Qfg-Outburst flood dep.(Pleis.), gravels, undiv.

wa

Qfg3-Outburst flood dep.(Pleis.), gravels, 2nd youngest

QPlg-Gravel (Pleistocene to Pliocene)

(1)

PlMc-Ringold Fm., Continental sed. (Plio.-Mio.)

PIMcg-Ringold Fm., Conglomerate (Plio.-Mio.)

Mv(sem)-Saddle Mt Basalt, Elephant Mt Mbr (U. Mio.)

Mv(se)-Saddle Mt Basalt, Esquatzel Mbr (M. Mio.)

Mv(su)-Saddle Mt Basalt, Umatilla Mbr (M. Mio.)

Mv(wpr)-Wanapum Basalt, Priest Rapids Mbr (M. Mio.)

Mv(wr)-Wanapum Basalt. Roza Mbr (M. Mio)

Qfg(3-4u)-Outburst flood dep., gravels, undif.

Qfis(3-4u)-Outburst flood dep., sands, undif.

Mc-Cont. sed. dep.-interbeds in Columbia R. Basalt

$\square$ WTR-Water

$\equiv$ FAULT-Fault

$\approx$ CONTACT-Contact between geologic units

Figure H-4. Legend for Hanford Geologic map. 
DOE/RL-94-24, Rev. 0

06/94

200-E Chemical Drain Field

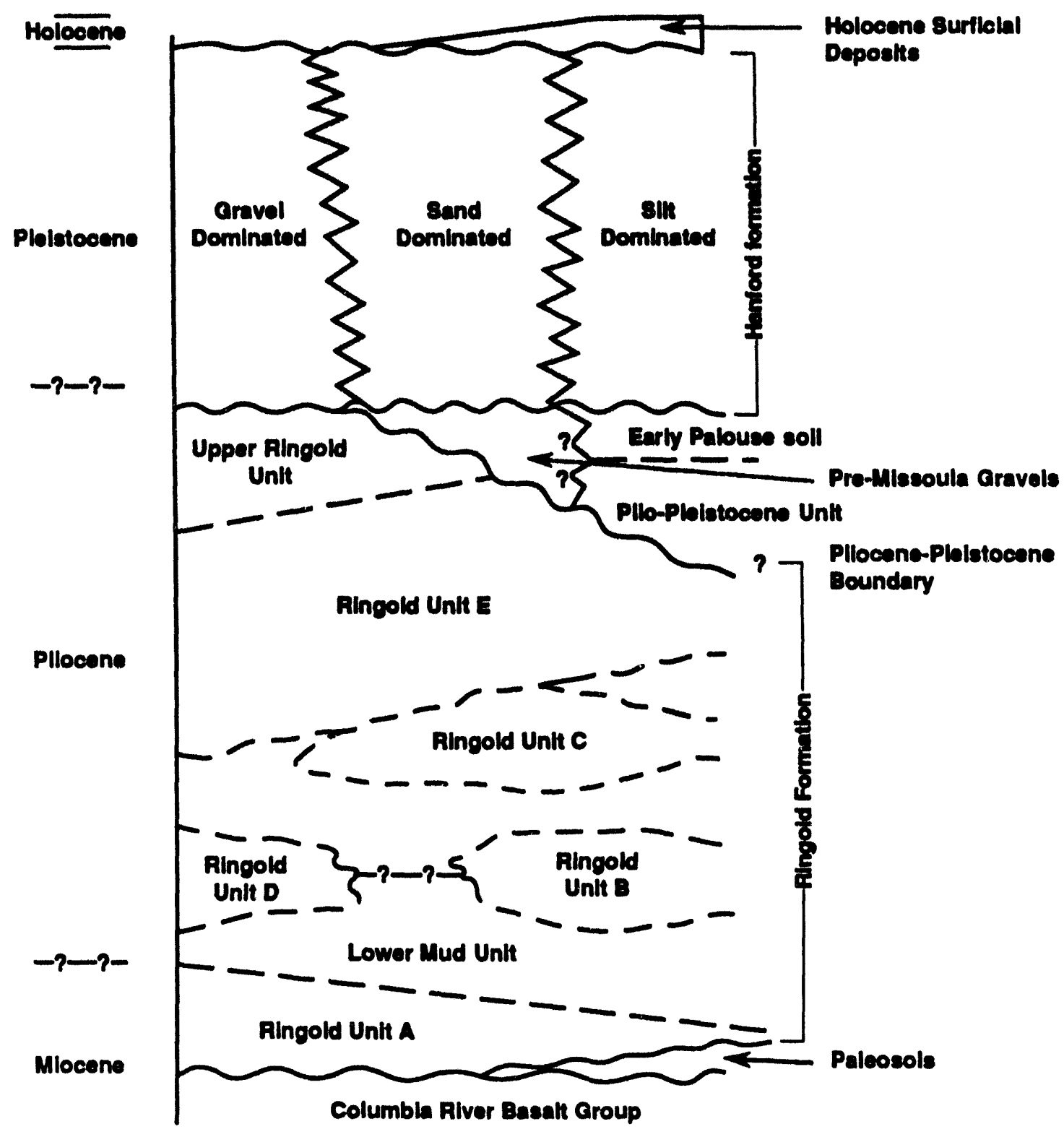

H8210018.1A

Figure H-5. Regional Stratigraphic Column. 


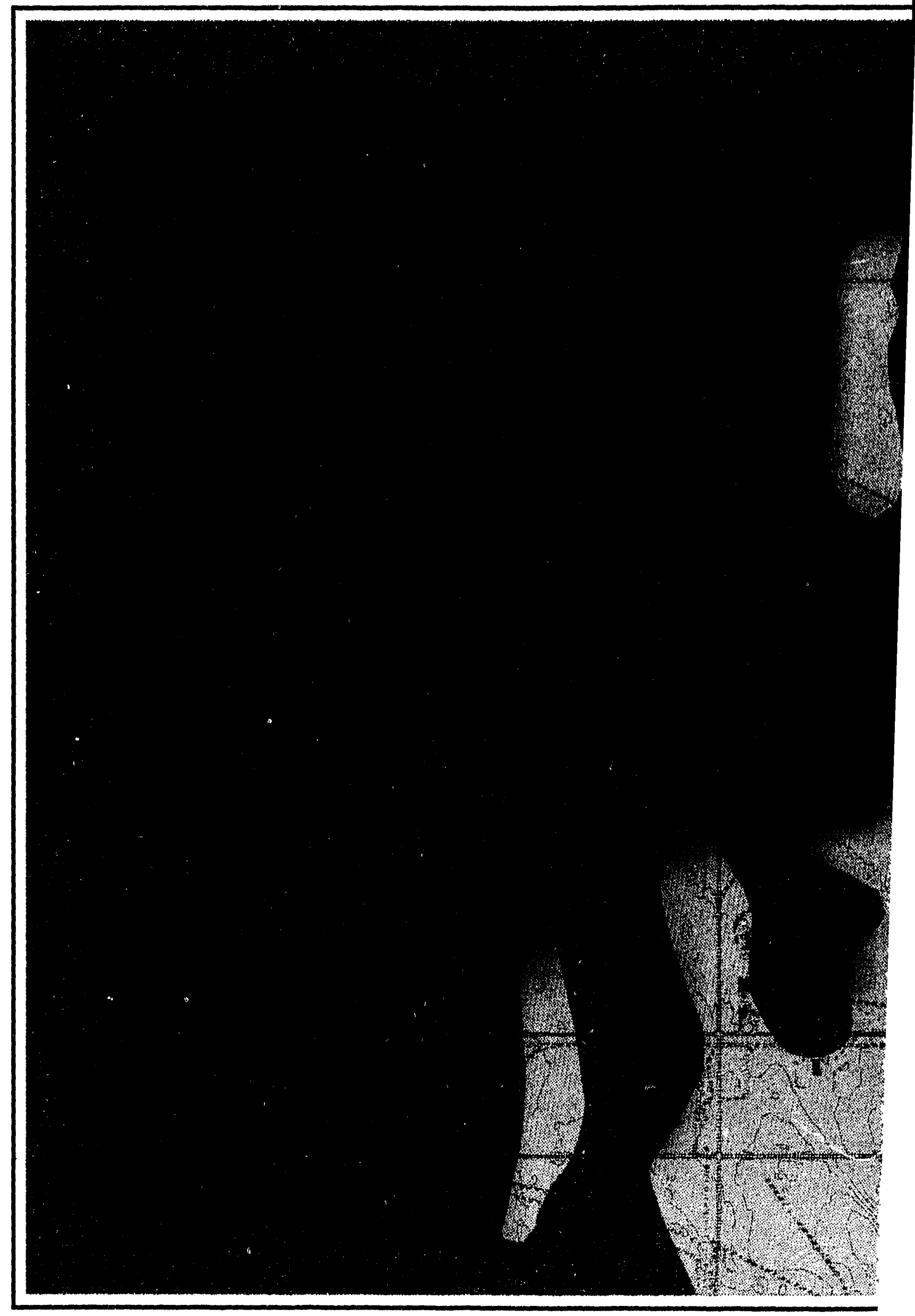


DOE/RL-94-24, Rev. 0

06/94

200-E Chemical Drain Field

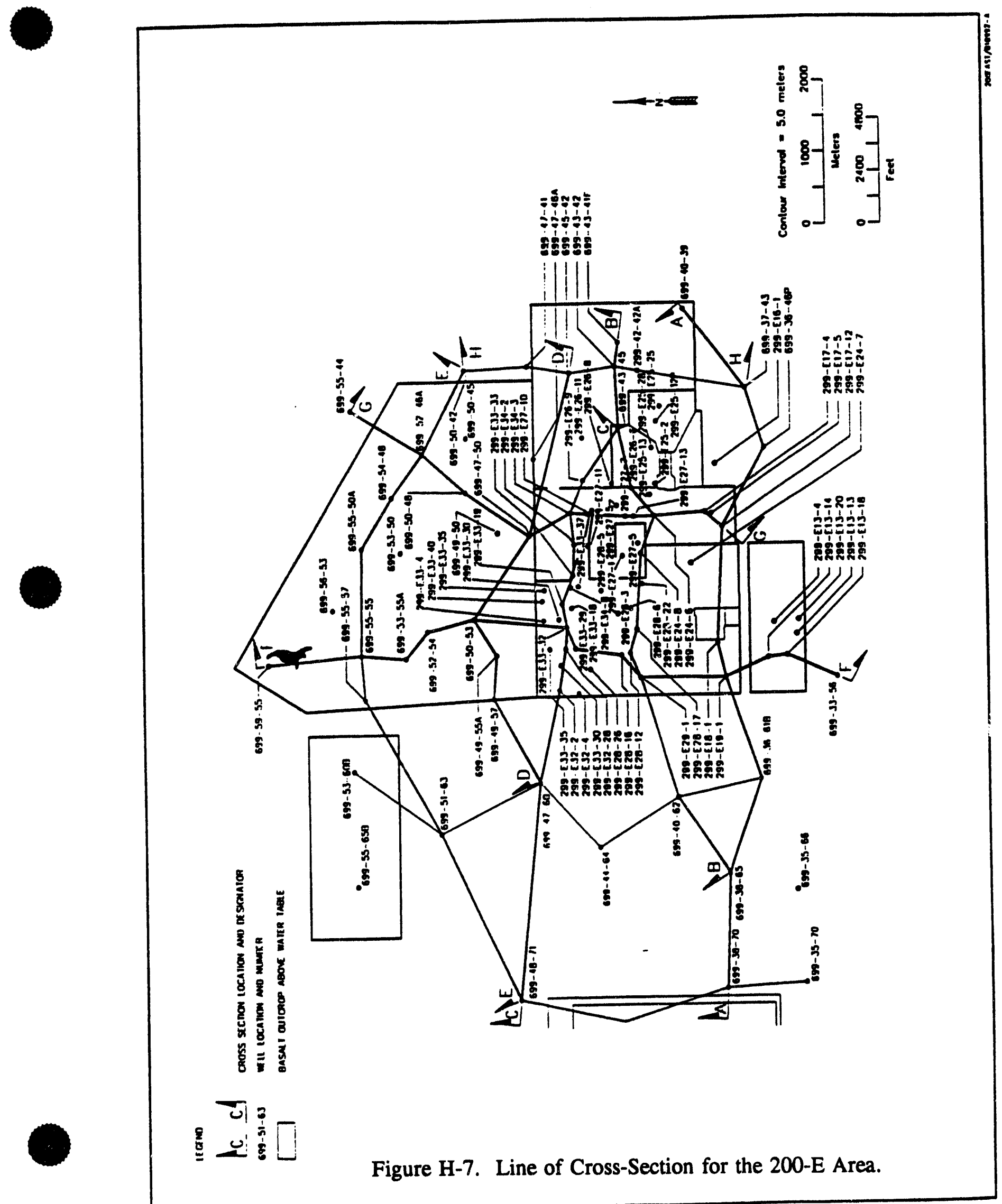



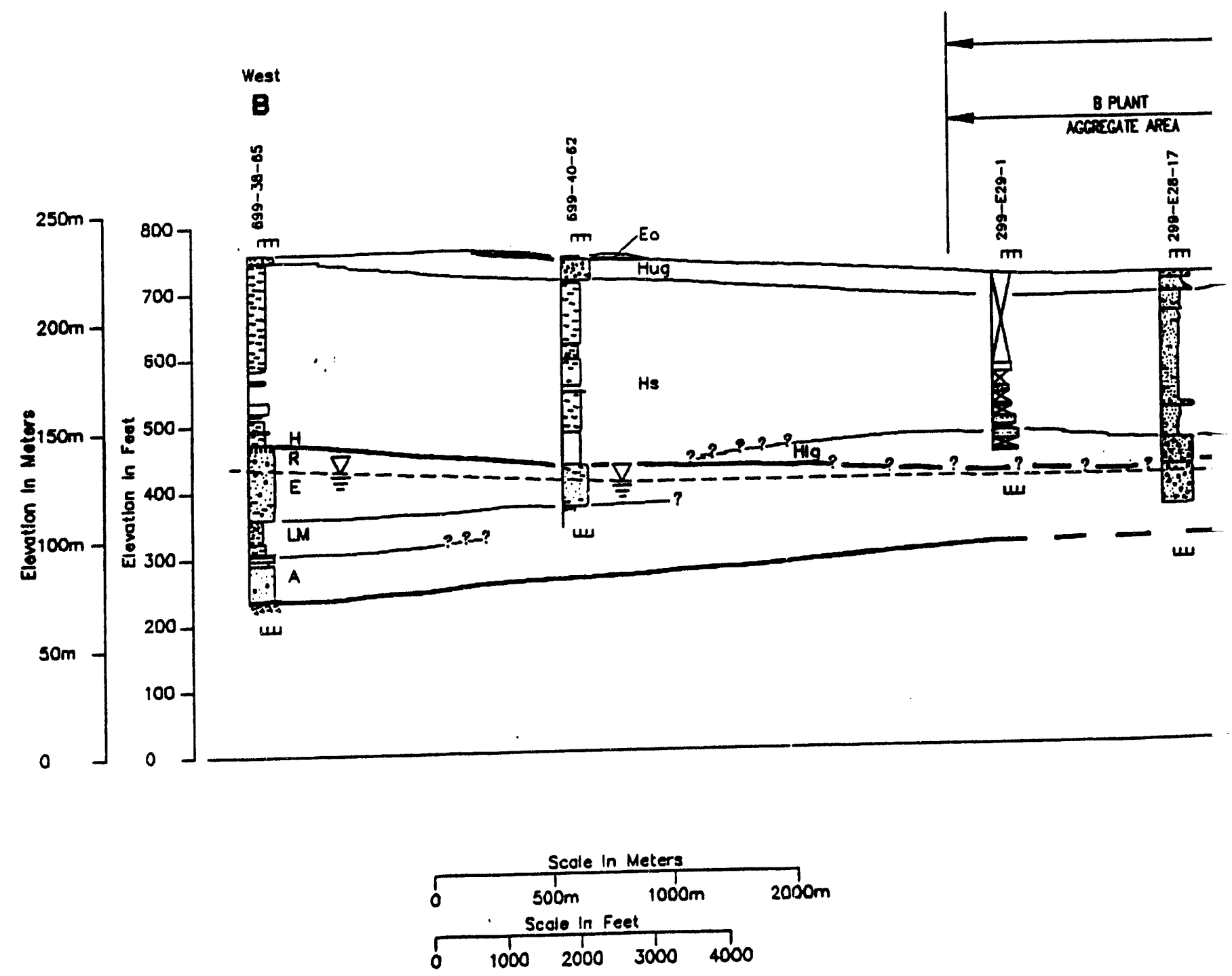


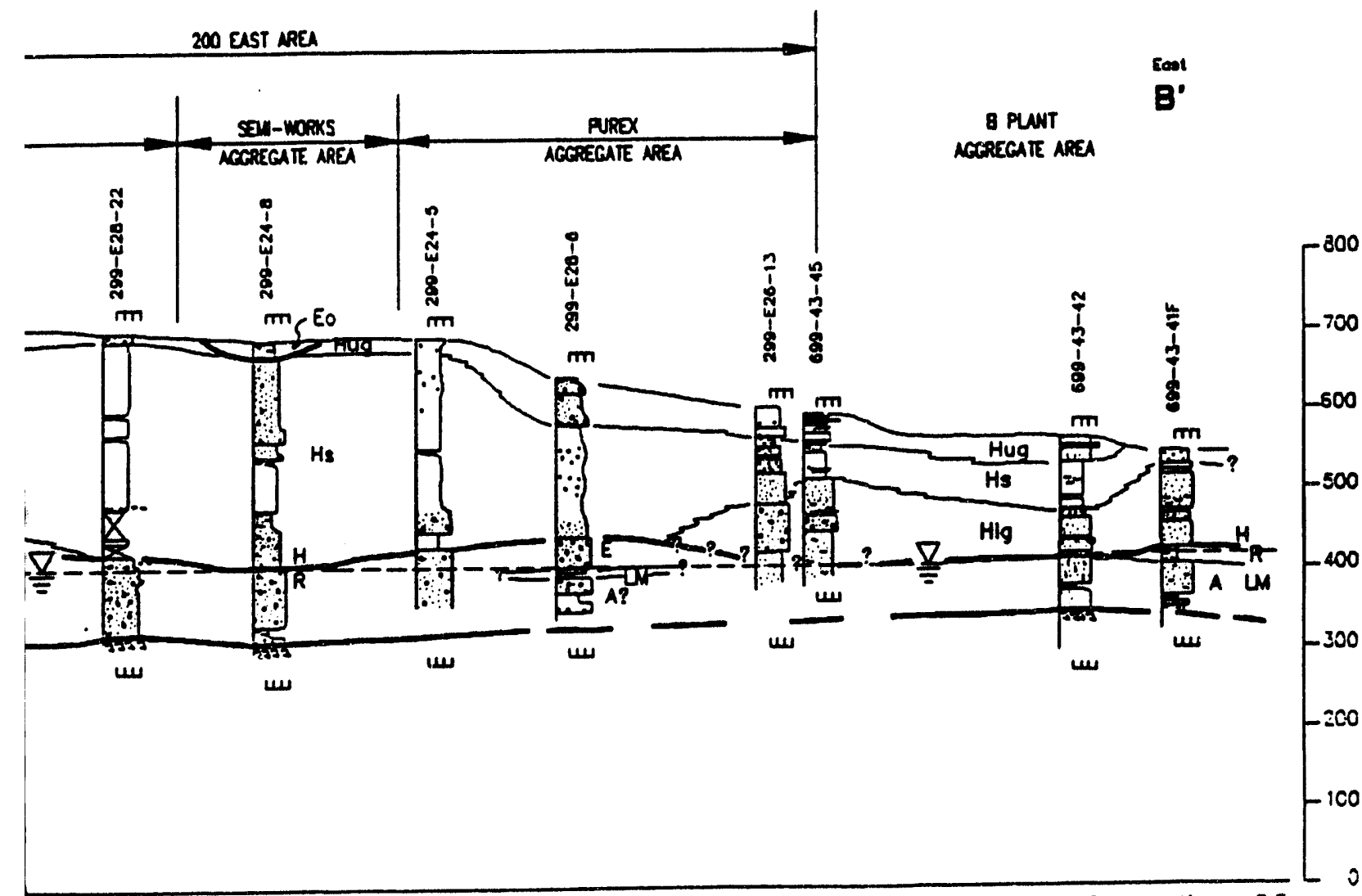

Unit Abbreviations

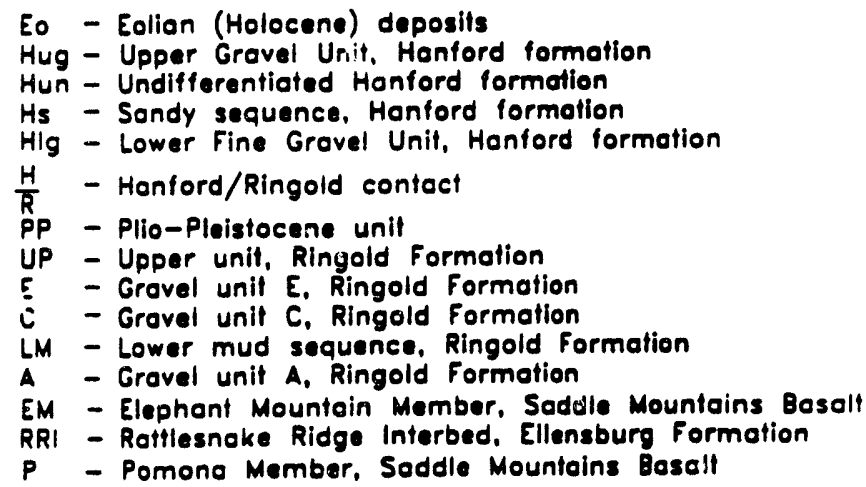

Figure H-8. Cross-Section for the 200-E Area. 

Number of Copies

\section{OFFSITE}

5 Washington State Department of Ecology

P.O. Box 1386, MSIN N1-05

Richland, WA 99352

Dave L. Lundstrom

David C. Nylander

Melodie A. Selby (2)

David B. Jansen

P.O. Box 47600

Olympia, WA $98504-7600$

\section{OSTI}

1 U.S. Environmental Protection Agency

Doug Sherwood - EPA Region 10

712 Swift Boulevard, Suite 5

Richland, WA 99352

ONSITE

5 U.S. Department of Energy,

Richland Operations Office

MSIN

D. C. Bryson

R3-80

J. E. Rasmussen

A5-15

J. E. Turnbaugh

A5-15

Reading Room (2)

$\mathrm{H} 2-53$

$1 \quad$ Pacific Northwest Laboratory

Hanford Technical Library

K1-11

16 Westinghouse Hanford Company

B. P. Atencio

H6-25

M. L. Bell

T6-16

S. E. Dieterle

S2-20

K. A. Giese

H6-25

D. L. Klages

S2-34

J. J. Luke

H6-25

C. E. Marple

S2-34

M. J. Schliebe

S4-25

S. J. Skurla

H6-28

J. D. Williams

H6-28

Central Files (1)

L8-04

EPIC (2)

H6-08

Information Release Administration (3)

H4-17 

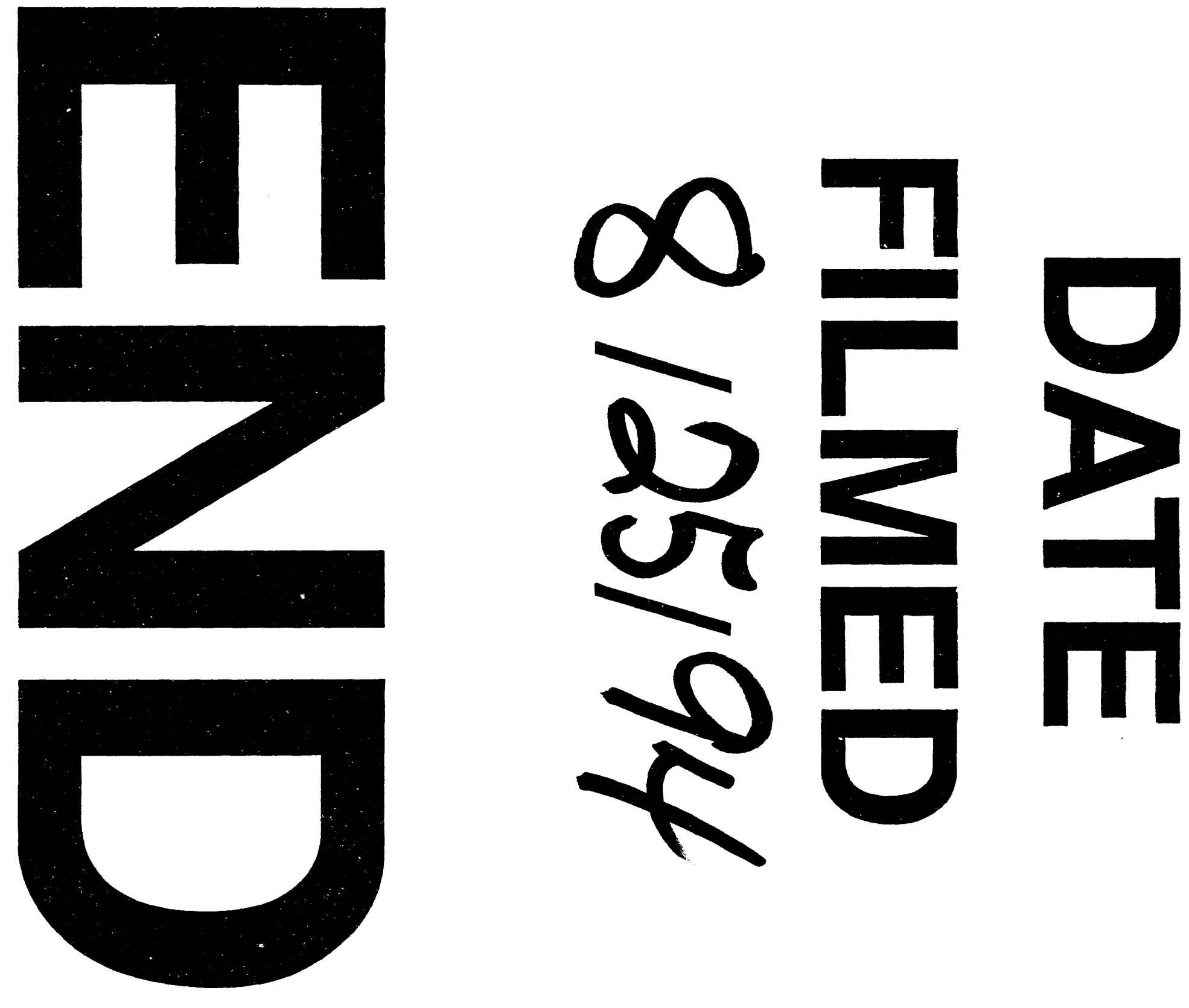


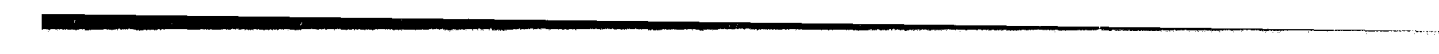

